\title{
Bibliográfia
}

\section{A 2012-ben megjelent, jog- és államtudományi tárgyú könyvek annotált bibliográfiája - 2. rész}

Folyóiratunkban rendszeresen jelenik meg az elmúlt időszak új, hazai szakkönyveiről készült, annotált bibliográfia. Az annotáció a könyv felhasználhatóságáról írott, rövid, tényszerü leírás, amely a bibliográfiai adatok mellett meghatározza a müfajt, illetve röviden körvonalazza a feldolgozott témát és a bemutatott eredményeket is. A mostani számban a 2012-ben megjelent könyvek nagyobbik részét dolgozzuk fel, amelyekröl a 2014/1. számban még nem közöltünk leírást. Annak megfelelően, hogy a Magyar Tudományos Művek Tára (MTMT) csak a 120 oldal terjedelmet elérő munkákat kezeli önálló kiadványként, az ettől jelentősen elmaradó kiadványokkal mi sem foglalkozunk. A bemutatás jogterületenként történik, a jogterületek elnevezésének, az egyes jogterületeken belül pedig a szerzők (szerkesztők) nevének Abc-rendjében következik. Zárásként a vegyes tárgyú tanulmányköteteket ismertetjük.

Első lépésként ezúttal is egy listát állítottunk össze különböző intézményi könyvtári katalógusok, a Magyar Országos Közös Katalógus (MOKKA), illetve az Országos Széchenyi Könyvtár interneten is közölt adatai alapján. Emellett kiadók honlapján, hírlevelekben, a szerzők publikációs listáiban és saját könyvespolcainkon is kutattunk. Gyüjtőmunkánkat jelentős mértékben segítette a Debreceni Egyetem Egyetemi és Nemzeti Könyvtára (DEENK), amely köteles könyvtárként a hazai kiadványok gyüjtését, feldolgozását, illetve részben - a mienkhez képest némileg eltérő szempontok szerint - annotálását is elvégzi. Ettől az évtől kezdve a DEENK Társadalomtudományi Könyvtár munkatársai egyéb adatbázisokat is figyelembe véve egészítik ki a listánkat, így az még pontosabb és teljesebb a korábbiaknál. Külön köszönettel tartozunk nekik érte.

A leírások elkészítése során általában a szerzők, kiadók által készített fülszövegeket, ajánlásokat, illetve a kötetekröl készült recenziókat is igyekeztünk fellelni és hasznosítani. Az annotációk azonban minden esetben úgy készültek, hogy az adott könyvet is a kezünkbe vettük, s ehhez, ha kellett, könyvtárközi kölcsönzéssel vagy más intézményekben dolgozó kollégáktól megkértük. Az annotációk tehát önálló feldolgozó munka eredményei.

Tisztában vagyunk azzal, hogy a feldolgozás szempontrendszere legjobb igyekezetünk ellenére is hiányos, illetve a sok szakterület és közremüködő okán egyenetlen. Örömmel veszünk és meg is szívlelünk ezért minden észrevételt, amely mun- 
kánkra vonatkozóan szerkesztöségünkhöz beérkezik. Szívesen fogadjuk azt is, ha a szerzők figyelmünkbe ajánlják saját könyvüket.

A leírások első, rövidebb része tartalmazza a könyvészeti adatokat (cím, szerzö/ szerkesztő, a kiadó neve, a kiadás helye és éve) az arra való utalással, hogy van-e a könyvben bibliográfia (irodalomjegyzék), illetve hogy a könyv milyen müfajba sorolható be. A terjedelmet oldalszámban adjuk meg, s közöljük a kötet azonosítására szolgáló ISBN-t, illetve sorozatok esetében az ISSN-t is. A második rész röviden leírja az alkotót, illetve alkotókat. Ezt követően (a változatlan utánnyomások kivételével) általában 6-12 sor terjedelemben számba vesszük a mü tárgyköreit, föbb eredményeit. $A z$ eredmények részletes értékelését azonban nem végezzük el. A gyüjteményes munkák esetében nem kerül sor valamennyi szerző név szerinti megemlítésére, $s$ a tanulmányok számától, tematikai egymáshoz kapcsolódásától függ, hogy minden témát megnevezünk-e. A felsőoktatási tananyagok, jogszabályközlések bemutatását a lehetö legtömörebben végezzük el.

Az annotációk szerzői valamilyen formában kivétel nélkül kapcsolódnak a Debreceni Egyetem Állam- és Jogtudományi Karához, legyen szó munkatársainkról, óraadóinkról vagy jelenlegi és volt hallgatóinkról. $A z$ annotációk végén szereplő monogramok feloldása a következő: Árva Zsuzsanna (Á. Zs.) egyetemi docens, Bagdi Katalin (B. K.) PhD-hallgató, Balogh Éva (B. É.) PhD-hallgató, Balogh Judit (B. J.) egyetemi docens, Barta Attila (B. A.) egyetemi adjunktus, Becánics Adrienn (Be. A.) egyetemi tanársegéd, Bencze Mátyás (B. M.) egyetemi docens, Bodó László (B. L.) PhD-hallgató, Bordás Péter (B. P.) PhD-hallgató, Dorka Dóra (D. D.) bírósági ügyintéző, abszolvált PhD-hallgató, Fazekas Flóra (F. F.) egyetemi adjunktus, Fekete Péter Pál (F. P. P.) joghallgató, Ferenczy Áron (F. Á.) joghallgató, Gócza Ágnes (G. Á.) joghallgató, Kémeri Zsófia Eszter (K. Zs.) PhD-hallgató, Keresztes Gergő Márk (K. G. M.) joghallgató, Kiss János Márk (K. J. M.) joghallgató, László Vilmos Csongor (L. V. Cs.) PhD-hallgató, Molnár Judit (M. J.) egyetemi adjunktus, Papp László (P. L.) egyetemi tanársegéd, Papp Nikolett (P. N.) PhD-hallgató, Papp Olga (P. O.) PhD-hallgató, Pető Alexandra (P. A.) PhD-hallgató, Skoda Gabriella (S. G.) PhDhallgató, Szabó Erzsébet (Sz. E.) abszolvált PhD-hallgató, Tomasovszky Edit (T. E.) PhD-hallgató, Tóth Andrea Noémi (T. A. N.) egyetemi tanársegéd, Ugrai Katalin (U. K.) joghallgató, Varga Judit (V. J.) egyetemi tanársegéd, Veczkó Judit (Ve. J.) PhDhallgató, Veszprémi Bernadett (V. B.) egyetemi adjunktus, Zsoldics Zsófia (Zs. Zs.) PhD-hallgató, Zsugyó Virág (Zs. V.) PhD-hallgató. Mellettük a bibliográfiai adatok összegyűjtésében közremüködött Brunda Anett joghallgató, az annotációk ellenőrzését pedig a szerkesztőség tagjai végezték.

\section{ALKOTMÁNYJOG, EMBERI JOGOK}

- Az állami egyházjog alapjai

Antalóczy Péter (szerk.)

(Sorozat: Bethlen-sorozat, ISSN 2062-2546)

Patrocinium, Budapest, 2012

Tankönyv. Terjedelem: 249. Bibliográfia a lábjegyzetekben. ISBN 9786155107887 
- Antalóczy Péter, a Károli Gáspár Református Egyetem Állam- és Jogtudományi Karának dékánja számos művet írt és szerkesztett egyházjogi témában 1996 óta, amikor Rómában publikálta összehasonlító jogtörténeti disszertációját kánonjogi posztgraduális tanulmányai végén. A hat szerző (közte az Alkotmánybíróság elnöke) által írt tankönyv 19 fejezeten át taglalja az állam és az egyház kapcsolatát időrendben haladva, elemzi viszonyuk egyes színtereit, majd értékeli a vallás és az egyház szerepét az oktatásban, a kulturális és szociális életben, a médiában. A könyv részletesen bemutatja a lelkiismereti és vallásszabadság érvényesülését az Emberi Jogok Európai Bírósága és a magyar Alkotmánybíróság gyakorlatában, illetőleg kitér az egyházakra vonatkozó legújabb hazai szabályozás föbb elemeire is. A mü nem csupán egyetemi hallgatók számára bizonyulhat hasznos tankönyvnek, hanem a témában elmélyülni vágyóknak is, hiszen az alapoktól építkezve boncolgat igen különleges és a hazai szakirodalomban mind ez ideig csak érintőlegesen értékelt témákat. (P. A.)

- Studies in the Fields of Comparative Law and Comparative Constitutional Law Badó Attila (szerk.)

Gateway Exchange Program, Shanghai-Szeged, 2012

Tanulmánykötet. Terjedelem: 129. Bibliográfia a lábjegyzetekben.

ISBN 9789630847735

- A kötet a Szegedi Tudományegyetem oktatóinak a korábban közölt írásait, illetve korábban elhangzott előadásait gyüjti össze. A közleményekben a szerzők öszszehasonlító jogi módszerekkel vizsgálják az alkotmányos alapjogokon belül az igazságszolgáltatás egyes alapvető téziseinek érvényesülését (mint a bírói függetlenség és ehhez szorosan kapcsolódva a bírák kiválasztásának kérdése, a tisztességes eljáráshoz való jog, a védelemhez való jog kérdése), illetve a büntetöügyekben a kétszeres értékelés tilalmának (ne bis in idem) problematikáját. (S. G.)

- Variációk a szabályozásra. Önszabályozás, társszabályozás és szabályozó hatóság a médiajogban

CsINK Lóránt-MAYER Annamária

(Sorozat: Médiatudományi Könyvtár, ISSN 2062-5222; 3.)

Médiatudományi Intézet, Budapest, 2012

Kézikönyv. Terjedelem: 120. Bibliográfia: 115-119. ISBN 9789630850223

- A szerzők elméleti és gyakorlati szakemberek, illetve oktatók. Munkájuk célja a médiajog szabályozásában 2010-töl bekövetkezett strukturális változások elemzése az alkotmányjogi és a médiajogi megközelítés ötvözésével, reflektálva a külföldi megoldásokra is. A kötet első fejezete tág keretek között vizsgálja a szabályozás szükségességét és a jogi szabályozás sajátosságait. A második fejezet témája az ön- és társszabályozás fogalma, fajtái, előnyei, hátrányai, feltételei, valamint megvalósulása. Ebben a fejezetben választ kaphatunk arra a kérdésre, hogy ezek a szabályozási formák mennyiben és mikor lehetnek a jogi szabályozás alternatívái. A harmadik fejezet a szabályozó hatóság és az önálló szabályozó szerv kérdéskörével foglalkozik, a következtetéseket a Nemzeti Média- és Hírközlési Hatóságra vonatkoztatva. A mű számos szakirodalmi forrást és nemzetközi dokumentumot dolgoz fel. Az áttekintést néhány ábra és táblázat segíti. (P. O.) 
- Az egyházi jogi személy a régi és az új egyházügyi törvényben

Csiziné Schlosser Annamária

(Sorozat: Sapientia luris: a Sapientia Szerzetesi Hittudományi Főiskola Egyházjog Tanszékének sorozata, ISSN 2061-7879; 3.)

L'Harmattan, Budapest, 2012

Kézikönyv. Terjedelem: 199. Bibliográfia: 186-199. és a lábjegyzetekben. ISBN 9789632365152

- A szerző főiskolai oktató. A kötet a szerző 2011 őszén megvédett doktori értekezésének az Alaptörvényre és az új egyháztörvényre tekintettel átdolgozott és bővített változata. A mü azt a kérdést járja körül, hogy minek tekinthető az egyház a jogban. Elsősorban az állami jog oldaláról, és nem a szüken vett belső egyházjog felöl közelítve az egyházak jogi státuszának átfogó feldolgozására vállalkozik. Először az egyház mint jogalany fogalmi összetevőit és az egyházi jogi személyek jogállását vizsgálja a magyar jogban, majd egy európai kitekintést követően részletesen elemzi a megváltozott hazai szabályozást. (Zs. V.)

- Magyar alkotmányosság az európai integrációban

DeZső Márta-Vincze Attila

Második, átdolgozott és bővített kiadás. HVG-ORAC, Budapest, 2012

Kézikönyv. Terjedelem: 572. Bibliográfia a lábjegyzetekben.

ISBN 9789632581453

- A szerzők egyetemi oktatók. A 2006-os kiadáshoz képest jelentősen átdolgozott kötet a teljesség igényével járja körül azokat az alkotmányjogi témaköröket, amelyekkel kapcsolatban az uniós tagság és az uniós jogalkotás hatása megfigyelhető a tagállamokban. Az egyes témakörök, így a csatlakozási klauzulák kérdése, az uniós és nemzeti jogrendszerek egymásra hatása, a hatáskörmegosztás vagy az alkotmánybíráskodás tárgyalása során mindig kitér a magyar fejleményekre is, már az Alaptörvény figyelembe vételével. Az alapvető alkotmányjogi kérdések (így a fentieken túl pl. a demokratikus legitimáció vagy az alapjogi bíráskodás) mellett a szerzők két speciális közjogi témát is tárgyalnak: az európai közigazgatási jogot és a nemzetközi kollíziós jogot. A kötetben foglalt ismeretek könnyebb átláthatóságát a jogszabály -és ítéletszövegek keretes kiemelése segíti. (F. F.)

- Technika vagy érték a jogállam? A jogállami értékek átadása és az elöitéletek csökkentése a jogászok és rendőrtisztek képzésében

FleCK Zoltán-KRÉMER Ferenc-NaVRATIL Szonja-UszkIEWICZ Erik

(Sorozat: Föld-rész könyvek, ISSN 2060-5404)

L'Harmattan, Budapest, 2012

Tanulmánykötet. Terjedelem: 196. Bibliográfia: 179-191. és a lábjegyzetekben. ISBN 9789632365770

- A szerzők egyetemi oktatók, kutatók. A tanulmánykötet egy joghallgatók és leendő rendőrtisztek körében végzett, az elöítéletességüket vizsgáló empirikus kutatáshoz kapcsolódóan született. Első felében a kutatás elméleti hátterét, előzményeit, illetöleg eredményeit ismerhetjük meg, a második felében az eredmények értékelését és konkrét javaslatokat olvashatunk. A könyvet személetessé teszik a 
kutatási adatokat képileg megjelenítő diagramok, a függelék pedig tartalmazza a kutatás során vizsgált minta elemzését, a használt kérdőívet, továbbá adatokat, eredményeket összesítő táblázatokat is. Mivel a kutatás eredményei azt mutatták, hogy a hallgatók körében jelen van a diszkriminatív gondolkodásmód, ezért a mü végkicsengése, illetve jövőre nézve megfogalmazott javaslata az, hogy erősíteni kell a leendő jogászok és rendőrtisztek képzése során a toleranciának, a jogállami, demokratikus értékeknek a hallgatók számára történő átadását. (Zs. Zs.)

- Az ombudsmani intézmények újraszabályozása a 21. században Magyarországon és Európában

Hajas Barnabás-Szabó Máté (szerk.)

Az Országgyülés Hivatala és az Alapvető Jogok Biztosának Hivatala, Budapest, 2012 Tanulmánykötet. Terjedelem: 302. Bibliográfia a lábjegyzetekben.

ISBN 9789639848566

- A szerkesztők egyetemi oktatók, Szabó Máté korábbi országgyülési biztos. A tanulmánykötet célja az ombudsmani intézmény átalakulásának vizsgálata, illetve nemzetközi összehasonlító perspektívába helyezése. A tanulmányok ezen öszszehasonlító módszer segítségével az intézmény helyét kívánják megmutatni az európai jogfejlődésben. Elemzik az ombudsman szerepét a demokratikus államokban, a hatalommegosztás rendszerében, illetve az egyes nemzetközi szervezetekben. A szerzők között jogászok és politológusok egyaránt vannak, így különböző nézőpontokból közelítenek, mely az ombudsmani intézmény komplex közjogi áttekintését eredményezi. (B. É.)

- Előadásvázlatok az adatvédelmi jog általános részéből

Hegedüs Bulcsú

(Sorozat: Wesselényi-sorozat)

Patrocinium, Budapest, 2012

Egyetemi jegyzet. Terjedelem: 111. Bibliográfia nincs. ISBN 9786155107542

- A szerző egyetemi oktató. A kötet az adatvédelem témakörének elsajátításához nyújt segítséget az egyetemi hallgatók számára. Az adatvédelmi jogot komplex módon ismerteti: az információs társadalom jellemzőitől elindulva a magánszféra védelméhez való jogot, a személyes adatok védelméhez való jogot, az adatvédelmi jogok generációit, az adatvédelem nemzetközi és magyar jogforrásait és a magyar adatvédelmi jog részletes szabályait (a jogviszony alanyai, az adatkezelés jogalapja, az érintett jogai, a NAIH eljárása) mutatja be. (B. É.)

- $A$ betegek jogairól

HidVÉginé AdorJÁn Lívia-SÁRInÉ Simkó Ágnes

(Sorozat: Orvos-beteg jogviszonyok az egészségügyben; 1.)

Medicina, Budapest, 2012

Kézikönyv. Terjedelem: 338. Bibliográfia nincs. ISBN 9789632263755

- A mü egy háromrészes sorozat első kötete, melynek célja, hogy az egészségügyi jog hazai szabályait rendszerbe foglalja. E kötet a betegek jogait tárgyaló kézikönyv, szerzői egyrészt az ítélkezési, másrészt a jogszabályalkotási munkában szereztek 
több évtizedes gyakorlatot. A könyv bemutatja és kommentálja az egészségügyröl szóló törvény kapcsolódó fejezeteit, továbbá az ún. speciális betegjogok körébe tartozó rendelkezéseket (pszichiátriai, fogyatékos betegek jogai, az otthonszüléssel, a betegszállítással, a hospice ellátásával kapcsolatos szabályok), és ismerteti az egészségügyi dolgozók jogait és kötelezettségeit is. A kötet kitér a betegjogok érvényesítésére lehetőséget adó eljárásokra is. (K. J.M.)

\section{- Hungarian Media Law}

Koltay, András (szerk.)

CompLex, Budapest, 2012

Kézikönyv. Terjedelem: 509. Bibliográfia a lábjegyzetekben. ISBN 9789632952512

- A szerkesztő a Médiatanács tagja, egyetemi oktató, a szerzők médiajogi szakemberek, alkotmányjogászok. A kötet célja a 2010-ben megalkotott új magyar médiaszabályozás komplex bemutatása angol nyelven. A kilenc fejezet ismerteti többek között a szabályozás alkotmányos alapjait, a közölhető tartalmakra vonatkozó korlátozásokat, a médiapiaci verseny szabályait, a közszolgálati média szabályozását és a NAIH szerepét. A kötet teljes terjedelmében közli a vonatkozó 2010-es törvények angol fordítását. A szerzők a témát magyar nyelven is átfogóan feldolgozták, az európai médiajogot is ismertetve, Európai és magyar médiajog címmel. (B. É.)

\section{- Emberi jogok és jogi kultúrák az Európai Unióban}

KondoRosi Ferenc

(Sorozat: Bologna-könyvsorozat (BSc), ISSN 1789-5103)

Saldo, Budapest, 2012

Kismonográfia. Terjedelem: 169. Bibliográfia a lábjegyzetekben.

ISBN 9789636384074

- A szerző egyetemi tanár. Könyvében az európai jogi kultúrák változásait elemzi, elsősorban a világgazdasági válság jogi és politikai következményeire tekintettel. A kötet számos témakört érint, az emberi jogok aktuális kérdéseitöl (pl. uniós alapjogvédelem, tisztességes eljárás) az európai biztonság új dimenzióinak kialakulásáig. A szerző álláspontja szerint az emberi jogok védelmének ügye napjainkra veszít jelentőségéből (lásd például a vallási öltözetek viselésének korlátozását vagy a terrorizmus elleni küzdelem ellentmondásait), így adódik a kötet alapvető kérdése: alkalmasak-e az európai jogi kultúrák választ adni korunk politikai, gazdasági, társadalmi kihívásaira? (Zs. V.)

- Az egyenlőség felé. A hátrányos megkülönböztetés tilalma és a támogató intézkedések

Kovács Kriszta

(Sorozat: Föld-rész könyvek, ISSN 2060-5404)

L'Harmattan, Budapest, 2012

Monográfia. Terjedelem: 229. Bibliográfia: 205-218. és a lábjegyzetekben. ISBN 9789632365343 
- A szerző egyetemi oktató, az Alkotmánybíróság korábbi főtanácsadója és a Velencei Bizottság korábbi munkatársa. A szerző doktori értekezésén alapuló kötet a hátrányos megkülönböztetés alapjait, fajtáit, valamint az arra megoldást nyújtó támogató intézkedéseket komplex módon mutatja be. A mű első néhány fejezete rámutat arra, hogy a közvetlen és közvetett diszkriminációra vonatkozó szabályok az emberi jogok egyenlö biztosításának nélkülözhetetlen elemei, amely - ahogyan a szerző az utolsó fejezetben kimutatja - különösen az esélykiegyenlítő intézkedéseken keresztül valósulhat meg. A szerző széles körben dolgoz fel hazai és külföldi bírósági eseteket, kitérve az Emberi Jogok Európai Bíróságának, valamint az Európai Unió Bíróságának esetjogára is. (K. Zs.)

- Váltóállitók között. Kővári Orsolya beszélgetései Kukorelli Istvánnal KöVÁRI Orsolya-KUKORELLI István

Osiris, Budapest, 2012

Interjúkötet. Terjedelem: 191. Bibliográfia nincs. ISBN 9789632762302

- Kukorelli István volt alkotmánybíró, egyetemi tanár. Az interjúkötet az ő életútját mutatja be tanulmányai megkezdésétől az alkotmánybírói tisztségig, onnan pedig napjainkig. A beszélgetéssorozat bepillantást nyújt abba is, hogy hogyan zajlott a rendszerváltás, hogyan alakult meg és hogyan müködött az Alkotmánybíróság. Kukorelli István az interjúk során kifejti véleményét többek között a jogászságról, a közéleti vitákról, a vallásról és az oktatásról is. A kötethez Sólyom László és Várszegi Asztrik írt elöszót. (B. É.)

- A varázsló eltöri pálcáját? A jogi szabályozás vonulata az asszisztált humán reprodukciótól a reproduktív klónozásig

NAVRATYIL Zoltán

Gondolat, Budapest, 2012

Monográfia. Terjedelem: 300. Bibliográfia: 279-300. és a lábjegyzetekben. ISBN 9789636934064

- A szerző egyetemi oktató. Doktori disszertációja alapján készült könyvében az asszisztált humán reprodukció magyar, amerikai, angol és német szabályozását vizsgálja átfogóan. Olyan jelenségek szabályozásával foglalkozik, amelyek alapvetően az emberi élet keletkezésére, az abba történő beavatkozásokra, a szülöségre vonatkoznak, s ennek megfelelően társadalmi, kulturális és történelmi okok miatt államonként eltérőek. A könyv három fö részböl áll: az I. rész az asszisztált reprodukció orvosi, történeti és eszmei alapjait ismerteti, a II. rész az asszisztált reprodukció gyakorlatát mutatja be a jogi szabályozás tükrében, a III. rész pedig az anyatesten kívüli embriókon végezhető beavatkozások, a velük való kutatások, kísérletek lehetőségeit tárgyalja. (B. É.) 
- A megfigyelés társadalmának proliferációjától az etnikai profilalkotáson át az állami felelösség kiszervezéséig. Alkotmányjogi és rendészettudományi megközelítések az emberi méltóság, a társadalmi biztonság és az adatvédelem értelmezésekor PAP András László (Sorozat: Föld-rész könyvek, ISSN 2060-5404)

L'Harmattan, Budapest, 2012

Monográfia. Terjedelem: 311. Bibliográfia: 279-303. és a lábjegyzetekben. ISBN 9789632365947

- A szerző az MTA TK Jogtudományi Intézetének kutatója, e munkája alapján nyerte el az akadémiai doktori címet. Könyve egyrészt a privátszektor szerepvállalásával foglalkozik a hagyományosan állami hatáskörbe tartozó rendészeti területeken, másrészt rávilágít a digitális és infokommunikációs technológia által meghatározott társadalomtípusnak, a megfigyelés társadalmának sajátosságaira, melynek napjainkra állandó velejárója a magánszféra sérelme. A kötet első része a rendészeti hatalom alkotmányos és társadalmi felfogásának változását vázolja fel, a második rész magyarországi esettanulmányok alapján az etnikai profilalkotás elméleti és gyakorlati kérdéseivel foglalkozik, a harmadik rész pedig a jogvédelmi lehetőségeket mutatja be. (Zs. V.)

- Nemzetközi Alkotmánybírói Konferencia, Nagykanizsa, 2012. március 1. Papp Attila (szerk.) Magánkiadás, Nagykanizsa, 2012 Konferenciakötet. Terjedelem: 113. Bibliográfia a lábjegyzetekben. ISBN 9789630845380

- A szerkesztő nagykanizsai származású jogász. A fényképekkel illusztrált kötet a Nagykanizsán 2012-ben rendezett Nemzetközi Alkotmánybírói Konferencián elhangzottak szerkesztett változatát adja közre. A rendezvényen a magyar, a horvát, a szlovák és a román alkotmánybíróság egy-egy tagja (hazánkból Kiss László), illetve a Közigazgatási és Igazságügyi Minisztérium közjogi jogalkotásért felelős helyettes államtitkára tartott előadást. A konferencia elsősorban az alkotmánybíróságok jogállamban betöltött szerepe köré szervezödött, különös tekintettel a közép-kelet-európai országok jogfejlődésére. (B. É.)

\section{- Adatvédelem és információszabadság a mindennapokban}

Péterfalvi Attila (szerk.)

HVG-ORAC, Budapest, 2012

Kézikönyv. Terjedelem: 480. Bibliográfia: 476-478. ISBN 9789632581637

- A szerkesztő a Nemzeti Adatvédelmi és Információszabadság Hatóság elnöke, a szerzők adatvédelmi jogi szakemberek. A kötet célja, hogy a gyakorlatban előforduló kérdések megválaszolásával segítséget nyújtson a 2012. január 1-jén hatályba lépett, az információs önrendelkezési jogról és az információszabadságról szóló 2011. évi CXII. törvény értelmezéséhez és alkalmazásához. A változások kiemelésével részletesen elemzi a törvény egyes rendelkezéseit, az alapelveket, illetve az adatkezelés új jogalapjait. Külön fejezetben tárgyalja a Nemzeti Adatvédelmi és Információszabadság Hatóság újonnan alakult intézményét, eljárását, illetve annak jogkövetkezményeit. (B. É.) 
- Állam és közösség. Válogatott közjogi tanulmányok Magyarország Alaptörvénye tiszteletére

Rixer Ádám (szerk.)

(Sorozat: Lőrincz Lajos Közjogi Kutatómühely)

KRE ÁJK, Budapest, 2012

Tanulmánykötet. Terjedelem: 426. Bibliográfia a lábjegyzetekben.

ISBN 9789639808386

- A tanulmányok szerzői többségükben a KRE ÁJK oktatói, illetve a Lőrincz Lajos Közjogi Kutatómühely hallgatói. A kötettel szakmai tiszteletadásukat kívánják kifejezni az új Alaptörvény felé. A 29 írás az Alaptörvény föbb rendelkezéseit elemzi, így például a Nemzeti Hitvallást, az Alapvetés egyes cikkeit, a büntetőjogi alapelveket, az egyházak jogi helyzetét, illetve az új választási rendszerre, az Alkotmánybíróságra, a bíróságokra és az önkormányzatokra vonatkozó új szabályozást. (Zs. V.)

- Magyarország kormányzása 1978-2012. A szoft diktatúra kormányzásától az újkapitalista konfliktusos demokrácia kormányzásán át a fülkeforradalom vezérdemokráciájának kormányzásáig

SÁRKÖZY Tamás

Park, Budapest, 2012

Monográfia. Terjedelem: 540. Bibliográfia: 507-528. ISBN 9789635309719

- A szerző az MTA TK Jogtudomány Intézetének kutatója, egyetemi tanár. A kötet az elmúlt több mint három évtized magyarországi kormányzását mutatja be. A szerző a magyar állam vezetésének tárgyilagos ismertetésére törekszik, ugyanakkor saját tapasztalatait is megosztja az olvasóval. A mü elsőként a kormányzáshoz kapcsolódó elméletet ismerteti fogalmakkal, kormányzási technikákkal, azok alkotóelemeivel. Ezt követően a magyarországi kormányzás kormányonkénti elemzése következik 1977-től 2010-ig. Az utolsó, a 2010-11-es kormányzati időszakkal foglalkozó fejezet azzal a konklúzióval zárul, miszerint az Alaptörvénnyel létrejött a negyedik magyar köztársaság államszervezete, amely alapjaiban különbözik a rendszerváltáskor létrejött szervezetrendszertöl. (B. É.)

- Állami egyházjog: vallásszabadság és vallási közösségek a mai magyar jogban SchANDA Balázs

(Sorozat: A Pázmány Péter Katolikus Egyetem Jog- és Államtudományi Karának tankönyvei, ISSN 2062-0837; Bibliotheca Instituti Postgradualis luris Canonici Universitatis Catholicae de Petro Pázmány nominatae. II. Manualia, ISSN 15891615)

Szent István Társulat, Budapest, 2012

Tankönyv. Terjedelem: 150. Bibliográfia a lábjegyzetekben.

ISBN 9789633618868

- A szerző egyetemi oktató, a vallásszabadsággal kapcsolatos jogi kérdések egyik elismert hazai szakértője, a mü pedig a legutóbb 2003-ban megjelent Magyar állami egyházjog címủ kötet második kiadásának átdolgozása. A tankönyv kiválóan összefoglalja a magyarországi vallási közösségek jogi helyzetét, körülményeit a hatályos magyar jogszabályi rendelkezések tükrében, szem előtt tartva azonban 
azt is, hogy elsődleges célja az, hogy tankönyvként szolgáljon. Az elmúlt időben a vallásszabadsággal, az állam-egyház viszonnyal kapcsolatban számos értékes mü jelent meg, amelyek egyrészt elméleti kérdéseket, másrészt különböző gyakorlati kérdéseket tárgyalnak. A jelen kötet az oktatási szempontok szem előtt tartása mellett arra törekszik, hogy a mai magyar állami egyházjogról átfogó képet adjon. (P. A.)

- Bibliográfia az alkotmányról, az Országgyülésröl, a központi állami szervekröl és a választási rendszerekröl

Soltész István (szerk.)

Harmadik, átdolgozott és bővített kiadás. Parlamenti Módszertani Iroda, Budapest, 2012

Bibliográfia-gyüjtemény. Terjedelem: 1347. ISBN 9789638420220

- A szerkesztő az Országgyűlés korábbi főtitkára. A gyüjtemény a korábbi (2004-es, illetve 2007-es) kiadásokhoz képest jelentősen kibővített jegyzékét tartalmazza az Országgyüléssel, a képviselőkkel és a választásokkal kapcsolatos szakirodalmi munkáknak, s e témakörök mellett számba veszi immár az egyes alkotmányos intézményekkel és külön az alkotmánnyal foglalkozó munkákat is. A vaskos kötetben helyet kapnak az Alaptörvénnyel kapcsolatos források is, és több fejezet bővült történeti visszatekintéssel és nemzetközi kitekintéssel is. Az új kiadás így közel 44 ezer címet tartalmaz. (F. F.)

- Az Országgyülés kolontári vizsgálóbizottságának tevékenysége 2010-2012. Az Országgyülés a Kolontár melletti vörösiszap-tározó átszakadása miatt bekövetkezett környezeti katasztrófával kapcsolatos felelösség feltárását és a hasonló katasztrófák jövőbeni megakadályozását célzó országgyülési vizsgálóbizottsága tevékenységéröl

Szalóki Gyula-Széles Zsuzsanna (szerk.)

Országgyülés, Budapest, 2012

Dokumentumgyüjtemény. Terjedelem: 167. Bibliográfia nincs.

ISBN 9789639848573

- A kötet Magyarország egyik legsúlyosabb következményekkel járó ipari katasztrófája, a kolontári vörösiszap-katasztrófa kapcsán létrejött vizsgálóbizottság közel egy éves tevékenységét mutatja be parlamenti dokumentumokon keresztül. Közreadja a vizsgálóbizottság létrejöttét megelőző jegyzőkönyvek részleteit, a bizottság ügyrendjét, a meghallgatottak névsorát, a szakértői véleményeket, és teljes terjedelmében közli a bizottsági vizsgálat eredményéröl kiadott J/4795. számú jelentést, amely egyrészt a katasztrófát kiváltó okokat és a felelősségi viszonyokat tárja fel, másrészt a szükséges intézkedésekre vonatkozó javaslatokat tesz. (B. É.)

- 20 years of the Committee on European Affairs

Tamás, Csaba Gergely-Járadi, Judit-Dóczy, Zsuzsánna (szerk.)

Hungarian National Assembly, Budapest, 2012

Kézikönyv. Terjedelem: 107. Bibliográfia: 89. ISBN nincs. 
- A kiadvány az Országgyülésben 1992 óta müködö Európai Ügyek Bizottsága megalakításának 20 éves évfordulója, illetve a 2012-ben elfogadott új szabályozás (Alaptörvény, Országgyülésről szóló törvény, új Házszabály) apropóján áttekinti a Bizottság történetét és addigi müködését. Külön fejezetben ismerteti az uniós csatlakozás előtti és utáni tevékenységet, illetve a magyar uniós elnökség időszakának speciális feladatait. Az angol nyelvű, képekkel, grafikonokkal gazdagon illusztrált kötet melléklete parlamenti ciklusonként közreadja a bizottsági tagok névsorát, illetve az uniós csatlakozás óta eltelt időszakban a bizottság által tárgyalt európai bizottsági jogszabálytervezetek listáját. (F. F.)

- Csoportkép Laokoónnal: a magyar jog és az alkotmánybíráskodás vívódása az európai joggal

VöRÖs Imre

HVG-ORAC, Budapest, 2012

Tanulmány. Terjedelem: 127. Bibliográfia: 121-127. és a lábjegyzetekben. ISBN 9789632581743

- A szerző az MTA TK Jogtudományi Intézet kutatóprofesszora, volt alkotmánybíró. Tanulmányában azt a kérdést járja körül, hogy hogyan hat egymásra a magyar és az európai uniós jogrendszer, és milyen következmények származnak e kölcsönhatásból. A magyar alkotmánybírósági gyakorlat elemzésén túl vizsgálja az uniós jog néhány kiemelt területén (versenyjog, nemzetközi kollíziós magánjog és társasági jog, uniós polgárság) a jogfejlődés magyar jogrendszerre gyakorolt hatását is. A kutatásnak összehasonlító jogi aspektusa is van, a magyar mellett ugyanis a cseh, a német és a francia alkotmánybíráskodást is vizsgálja az uniós joghoz való viszony szempontjából. A munka az itt jelzett mellett az MTA Jogtudományi Intézet kiadásában is elérhető. (F. F.)

\section{BÜNTETŐJOG, BÜNTETŐ ELJÁRÁSI JOG}

- Korrupció: büntetés, integritás, kompetencia BÁger Gusztáv Akadémiai, Budapest, 2012 Monográfia. Terjedelem: 343. Bibliográfia: 275-281. ISBN 9789630592529

- A szerző közgazdász, egyetemi tanár. A könyv céljai között szerepel, hogy megismertesse az olvasóval a hazai és külföldi, illetve nemzetközi szervezetek korrupcióellenes gyakorlatait, bemutassa a megelőzést középpontba állító személyi és szervezeti integritás kultúráját, valamint javaslatokkal segítse a gyakorlat fejlesztését. A kötet tizenhárom fejezetböl áll és az elméleti ismeretek részletezése mellett a gyakorlati alkalmazás követelményeire is koncentrál. Szemléletesek a statisztikai adatokat is bemutató mellékletek és az olvasó számára megkönnyíti a keresést a kötet végén található név- és tárgymutató. (G. Á.) 
- Tanulmányok Irk Ferenc Professzor 70. születésnapjának tiszteletére Barabás A. Tünde (szerk.)

Országos Kriminológiai Intézet, Budapest, 2012

Tanulmánykötet. Terjedelem: 284. Bibliográfia: a lábjegyzetekben. ISBN 9789637373183

- A szerzők elméleti és gyakorlati szakemberek, az Országos Kriminológiai Intézet munkatársai. A tanulmánykötetben a büntetőjog széles spektrumát érintik a feldolgozott anyagok. A mü Irk Ferenc professzor 70. születésnapjának tiszteletére íródott. A téma szakértői által megismerhetünk a büntetés-végrehajtás, a jogtörténet, a kriminológia, a rendészettudomány, a büntetőeljárás és a büntető anyagi jog kérdésköréből különböző értekezéseket, amelyek aktuális problémákra próbálnak választ adni. A kötet kuriózumát az is növeli, hogy német és angol nyelvü tanulmányokat is tartalmaz. (F. P. P.)

- Responsibility-taking, relationship-building and restoration in prisons: mediation and restorative justice in prison settings

Barabás, Tünde-Fellegi, Borbála-Windt, Szandra (szerk.)

Foresee Research Group and the National Institute of Criminology, P-T Mühely, Budapest, 2012

Tanulmánykötet. Terjedelem: 327. Bibliográfia: 309-319. ISBN 9789638946812

- A kötetben található tanulmányok a Magyarország, Anglia, Németország és Belgium büntetés-végrehajtásában megjelenő resztoratív és mediációs lehetőségeket mutatják be angol nyelven, a „MEREPS”, azaz a „Mediation and Restorative Justice in Prison Settings" címü, az Európai Bizottság támogatásával megvalósult projekt keretében. Ezen túlmenően még három esettanulmányt is találunk, a függelék pedig Anglia és Wales témához kapcsolódó, fontosabb jogszabályváltozásait foglalja össze. A témában való elmélyülést és alapos kutatást segíti a könyv végén található hivatkozások jegyzéke, valamint a szerzők tudományos munkásságát bemutató összefoglaló. (T. A. N.)

- Az új Szabálysértési törvény magyarázata. Gyakorlati kérdések és válaszok a szabálysértési jog köréböl

BIsZTRICZKı László-KáNTÁs Péter

HVG-ORAC, Budapest, 2012

Kézikönyv. Terjedelem: 672. Bibliográfia a lábjegyzetekben.

ISBN 9789632581569

- A könyv szerzői gyakorlati szakemberek és egyetemi oktatók. 2012-ben hatályba lépett az új Szabálysértési törvény, amely a hatékony és gyors eljárás, mint jogalkotói cél megvalósulását igyekszik előmozdítani. A mű kódex-jellegűen foglalja össze az anyagi és eljárási jogi rendelkezéseket, a szabálysértési tényállásokat, továbbá a központi nyilvántartási rendszerre vonatkozó szabályokat. A törvény több helyen szigorításokat vezetett be, amelyek még inkább növelni fogják a törvényes és egyben gyors jogalkalmazásra való ügyintézői és „ügyféli” igényt. A szerzők célja a könyv megírásával ennek az igénynek a kielégítése, illetve a törvény gyakorlati alkalmazásához történő segítségnyújtás volt. (G. Á.) 
- Büntetőeljárási jog I.

Dobrocsı Szilvia

(Sorozat: Werbőczy-sorozat, ISSN 2062-2538)

Harmadik, átdolgozott kiadás. Patrocinium, Budapest, 2012

Egyetemi jegyzet. Terjedelem: 193. Bibliográfia nincs.

ISBN 9786155107795

- A szerző egyetemi oktató, célja a büntetőeljárás szemináriumi oktatása során használható jegyzet készítése volt. E kötet a büntetőeljárás alapjaitól a vádig jut el, s minden fejezet végén a tananyag elsajátítását segítő ellenőrző kérdéssort találunk. A könyv végén függelékként az Alkotmánybíróság válogatott határozatai, valamint a kapcsolódó jogegységi határozatai jelennek meg. Az elméleti anyag gyakorlatba ültetéséhez hozzájárul a kötet végén található iratmintatár a nyomozó hatósági, ügyészi és bírósági határozatok anyagából, melyek nem egyedi ügyeket mutatnak be, hanem egy kitalált jogesethez kapcsolódnak, s az egyes határozattípusok valamennyi kellékét tartalmazzák. (T. A. N.)

- Börtönkönyv. Kulturális antropológia a rácsok mögött

Fı́́TH Titanilla

Háttér, Budapest, 2012

Monográfia. Terjedelem: 249. Bibliográfia: fejezetenként. ISBN 9786155124044

- A szerző 2004 óta dolgozik börtönpszichológusként felnőtt korú, férfi és női fogvatartottakkal. Az író a munkája során szerzett tapasztalatok alapján mutatja be a magyarországi börtönök világát, azokat az íratlan szabályokat, amelyek meghatározzák a fogvatartottak egymás közötti viszonyát, illetve a „rács mögötti életet”. A könyv a fogvatartottak szemszögéből mutatja be a büntetés végrehajtási intézetek müködésének szinte minden területét. Az olvasó betekintést nyerhet - többek között - a térhasználat, a formaruha, a nemi identitás és a státusszal kapcsolatos szokásokba. A mű a börtönélet kulturális antropológiai szempontból történő vizsgálatának az eredménye. A kötetben szereplő, fogvatartottak által használt kifejezések magyarázatát a könyv végén található „szlengszótár” tartalmazza. (G. Á.)

- A pénzmosással és a terrorizmus finanszírozásával kapcsolatos jogszabályok magyarázata

GÁL István László

HVG-ORAC, Budapest, 2012

Monográfia. Terjedelem: 518. Bibliográfia: 513-517. ISBN 9789632581712

- A szerző egyetemi oktató és gyakorlati szakember. A pénzmosás jogi szabályozásában nagymértékű változást eredményezett a 2007. évi CXXXVI. törvény - ami az Európai Unió harmadik pénzmosási irányelvének való megfelelést szolgálja -, valamint a 2012. évi C. törvény, az Új Büntető Törvénykönyv. Ehhez az új jogszabályi környezethez igazodik a könyv. Az első nagyobb tematikai egység egy kriminológiai bevezetés, amelyben a fogalmak meghatározását és az elkövetési technikákat mutatja be a szerző. A második rész a jogszabályok ismertetését tartalmazza kommentárszerüen. Ez a magyarázat magába foglalja a témával kapcsolatos büntetőjogi, pénzügyi és igazgatási szabályokat egyaránt. Az utolsó 
nagyobb egység tartalmazza a függeléket, amelyben az olvasó megtalálja az öszszes vonatkozó nemzetközi és hazai jogszabályi rendelkezést. (G. Á.)

- Legality on trial: a theoretical analysis of the legality of substantive criminal norms GeLLér Balázs József

Eötvös Lóránd Tudományegyetem, Budapest, 2012

Monográfia. Terjedelem: 301. Bibliográfia: 259-290. ISBN 9789633120859

- Aszerző egyetemi oktató, ügyvéd. Könyvében az anyagi joghoz kapcsolódó és befolyásoló erővel bíró büntetőjogi legalitást vizsgálta a bírói jogalkotás tilalma és az előreláthatóság követelményének tükrében. A mű első részében a kriminalizáció kettőségét tárgyalja, érintve a büntetőjogi normák címzettjeit, majd ezt követően három dimenzión keresztül - idő, többség, integritás - mutatja be az értelmezés és a büntetőjogi normák függvényét. A szerző a kötet végkövetkeztetésként megállapítja, hogy az abszolút emberi jogok védelme az állam kötelessége, melyet akár még visszaható hatályú jogalkotással is megtehet. $A$ mü különlegességét támasztja alá, hogy angol nyelven íródott, terjedelmes külföldi bibliográfiát illetve függelékeket tartalmaz, amelyek tovább növelik az alkotás tudományos megalapozottságát, és jó kiindulópontot nyújthatnak a további kutatások számára. (F. P. P.)

\section{- Büntetöjogi fogalomtár}

GöRgÉNYI Ilona et al.

CompLex, Budapest, 2012

Tansegédlet. Terjedelem: 351. Bibliográfia nincs. ISBN 9789632950716

- A tansegédlet a büntető anyagi jogi- és eljárásjogi fogalmakat és azok magyarázatait gyűjti össze. Célja, hogy megkönnyítse a jogi egyetemek hallgatóinak a vizsgára való felkészülését és a tananyag jobb megértését. A kötetnek a Büntető Törvénykönyv és a büntetőeljárásról szóló törvény címszavaira épülő tartalma és betürend szerinti elhelyezése megkönnyíti az eligazodást. (F. P. P.)

\section{- Magyar Büntetőjog: Általános Rész}

Horváth Tibor-Lévay Miklós (szerk.)

CompLex, Budapest, 2012

Tankönyv. Terjedelem: 558. Bibliográfia: 553-558. ISBN 9789632952390

- A kötet a Miskolci Egyetem Állam és Jogtudományi Karának Büntetőjogi és Kriminológiai Tanszéke által összeállított, azonos című tankönyvének a 2012. évi C. törvény alapján átdolgozott kiadása. Elsősorban egyetemi joghallgatók számára készült, azonban a szerzők ajánlják gyakorló jogászoknak is. A tankönyv követi a Büntető Törvénykönyv Általános Rész szerkezetét, figyelemmel a magyar és az európai büntetőjog-tudomány fejlődésére. Ismerteti a vonatkozó bírói gyakorlatot a kúriai és az alkotmánybírósági jogesetek feldolgozásán keresztül. (G. Á.)

\section{- Kételkedő kriminológia}

IRK Ferenc

Bíbor, Miskolc, 2012

Monográfia. Terjedelem: 438. Bibliográfia: 355-412. ISBN 9789639988378 
- A szerző egyetemi oktató. A könyvvel édesapja emléke előtt tiszteleg, aki a kriminológiai kutatások egyik alapítója volt száz évvel a könyv megjelenése elött. A szerző a veszélyek széles választékát tárja az olvasó elé a büntető tudományok módszereit alkalmazva, hanyagolva ily módon a biztonságelmélet kínálta módozatokat. A monográfia három tárgykört elemez mélyrehatóan. Az első egység a kockázat társadalomban játszott szerepét vizsgálja, a második rész a globalizáció kérdéskörét elemzi, a harmadik nagy téma pedig a demokrácia. A munka nem tartalmaz dogmatikai alapvetést és eljárásjogi elemzést, a kötet kriminológiai tanulmány. Az alapos kutatómunkát igazolja a felhasznált irodalom figyelemre méltó mennyisége. A könnyebb eligazodást a szöveg végén található névmutató segíti. (G. Á.)

- Közigazgatási büntetöjog Jacsó Judit-Sántha Ferenc Miskolci Egyetemi Kiadó, Miskolc, 2012 Jegyzet. Terjedelem: 158. Bibliográfia: 157-158. ISBN 9786155216343

- A szerzők egyetemi oktatók. A jegyzet a szűkebb értelemben vett közigazgatási büntetőjog, vagyis a szabálysértési jog elsajátításában nyújt hatékony segítséget. A szerzők a szabálysértésekről, a szabálysértési eljárásról és a szabálysértési nyilvántartási rendszerről szóló 2012. évi II. törvény szabályanyagát rendszerezik, mellőzve a szabálysértési nyilvántartási rendszer ismertetését, valamint részlegesen érintve a közigazgatási bírságolást. A könyv általános részében kerül bemutatásra az anyagi-, eljárási, és végrehajtási jog, a különös részben pedig az egyes szabálysértési tényállások részletes elemzésére kerül sor. Vizsgára való felkészülés során megfelelő támpontot nyújt a joghallgatók számára, valamint az érdeklődő állampolgárok számára is az eljárás elemeinek megismeréséhez. (F. P. P.)

- Válogatás a Magyar Kriminológiai Társaság 2011. évben tartott tudományos rendezvényein elhangzott előadásokból

Kadlót Erzsébet (szerk.)

(Sorozat: Kriminológiai közlemények, ISSN 0236-9893; 70.)

Magyar Kriminológiai Társaság, Budapest, 2012

Tanulmánykötet. Terjedelem: 284. Bibliográfia az egyes tanulmányok végén. ISBN 9789638016225

- A szerzők elméleti és gyakorlati szakemberek, a bünügyi tudományok haza müvelöi, akik több tudományos tanácskozást és kerekasztal beszélgetést tartottak a Magyar Kriminológiai társaság égisze alatt 2011-ben. A téma szakértői által tartott elöadások, szekciókba csoportosítva kerültek rögzítésre, úgy, mint a viktimológia, korrupció, jogos védelem, büntetés-végrehajtás stb. A kötet újdonsága, hogy rendhagyó módon a büntetőjog, kriminológia és a szociológia kapcsolódási pontjaira figyelemmel születtek meg a publikációk, így lehetőség nyílott a Magyar Szociológiai Társasággal és a Szegedi Tudományegyetem Igazságügyi Orvostan Intézetével való kooperációra is. (F. P. P.) 
- Igazságügyi orvosi tanulmányok Varga Tibor 70. születésnapja alkalmából (Forensic medical studies for Varga Tibor's $70^{\text {th }}$ birthday)

Kereszty Éva (szerk.)

Szegedi Tudományegyetem Általános Orvostudományi Kar Szent-Györgyi Albert Klinikai Központ Igazságügyi Orvostani Intézet, Szeged, 2012

Tanulmánykötet. Terjedelem: 160. Bibliográfia a tanulmányok végén.

ISBN 9789633061800

- Varga Tibor nemcsak a szegedi orvosegyetemi képzés oktató professzora, hanem az orvosszakértői munka lényegi korszerüsítésének egyik meghatározó alakja e terület joganyagának kidolgozásában is. Tudományos munkássága középpontjában a közlekedési balesetek vizsgálata állt, mely később a toxikológia felé vezette, ezért kollégái által a professzor születésnapja tiszteletére készített kötet tanulmányai is föként az általa vizsgált területekröl kerültek ki. A tanulmányok az igazságügyi orvostan és az egészségbiztosítási orvostan néhány, a büntetőeljárás során is relevanciával bíró területét mutatják be táblázatokkal, diagramokkal szemléltetve. (T. A. N.)

\section{- A büntetöjog alapproblémái}

KöHALMı László

PTE ÁJK Gazdasági Büntetőjogi Kutatóintézet, Pécs, 2012

Monográfia. Terjedelem: 244. Bibliográfia: fejezetenként. ISBN 9786155290015

- A szerző egyetemi oktató és ügyvéd. A kötetben olyan dogmatikai kérdéseket vizsgál, amelyek egyrészt saját szakmai érdeklődésének tárgyát képezik, másrészt a büntető jogalkotásban és jogalkalmazásban gyakran felmerülnek. Így elemzi az elévüléssel kapcsolatos anomáliákat, kitér a társadalomra veszélyesség kategóriájára, körbejárja a kóros elmeállapot, mint büntethetőséget kizáró ok és az életveszélyt okozó testi sértés szabályozástörténetét. Egy külön fejezetben foglalkozik a környezeti büntetőjog problémáival. Az utolsó fejezet német nyelven íródott, és a korrupció elleni harccal foglalkozik. (G. Á.)

- Szakmai módszertani útmutató a párkapcsolati erőszak elleni hatékony fellépésre Kuszing Gábor-SPRONz Júlia-WIRTH Judit

(Sorozat: Tüz-hely füzetek, ISSN 1788-6546)

NANE Egyesület-Patent Egyesület, Budapest, 2012

Kézikönyv. Terjedelem: 182. Bibliográfia: 178-182. ISBN 9789638811684

- Kuszing Gábor pszichológus, Spronz Júlia jogvédő, gyakorló ügyvéd, Wirth Judit a Nők a nőkért együtt az erőszak ellen (NANE) nevü szervezet jogásza. A szerzők mellett más szakemberek is közremüködtek a mü elkészítésében, amelynek célja elsősorban a párkapcsolati erőszak elleni fellépés nemzetközi gyakorlatának bemutatása és meghonosítása volt. Nyolc fejezetben dolgozzák fel a tárgykört, külön tárgyalva az ügyészek, bírók, gyermekvédelmi szakemberek, gyámhatósági munkatársak, rendőrök, pszichológus szakértők és egészségügyi dolgozók számára szánt protokollrészletességű ajánlásokat. A kötet segítséget nyújt a partnerkapcsolati erőszaknak nevezett jogsértés elkövetőjének felelősségre vonásához, az áldozatok biztonságának a megtervezéséhez illetve az ellentmondásos magatartások definiálásához. (F. P. P.) 
- Büntetés-végrehajtási jogi alapfogalmak

LöRINCZ József-NAGY Anita

Miskolci Egyetemi Kiadó, Miskolc, 2011

Egyetemi jegyzet. Terjedelem: 132. Bibliográfia nincs. ISBN nincs.

- A kötet sajnálatos módon kimaradt a 2011-es megjelenések bibliográfiájából. A Miskolci Egyetemen készült jegyzet elsősorban a jogi asszisztens képzésben részt vevők számára íródott. Szerkezete alapvetően az 1998-as büntetőeljárási törvényhez igazodik: elsőként a büntető eljárásjog általános részével foglalkozik (alapelvek, alanyok, bizonyítás, kényszer-intézkedések stb.), majd áttér a különös részre (nyomozás, vádemelés, bírósági eljárás, jogorvoslatok). (F. F.)

- Büntetőjogi kodifikációk alkonyán és hajnalán

MÉszÁros Ádám

Virágmandula, Pécs, 2012

Monográfia. Terjedelem: 177. Bibliográfia: 172-177. ISBN 9786155181436

- A szerző egyetemi oktató, valamint az Országos Kriminológiai Intézet munkatársa. A büntetőjogi felelősség körében jellemző anyagi jogi stabilitás a megannyi törvénymódosítás következményeként megbomlott. A kutatatás célja egy dogmatikailag koherens törvényszöveg megalkotásához kívánt segítséget nyújtani. Ennek érdekében az írás tartalmazza az elmúlt időszakban napvilágot látott megoldási javaslatokat és azok értékelését. A kötet második és egyben hangsúlyosabb része a büntetőjogi felelősség egyes területeivel foglalkozik, amely magába foglalja a büncselekmény fogalmának, a társadalomra veszélyesség és a jogellenesség, a jogos védelem és a megelőző jogos védelem, illetve a bủncselekmény elkövetőinek elemzését. (G. Á.)

- A bün nyomában. A budapesti bünözés társadalomtörténete 1896-1914

PERÉnYI Roland

L'Harmattan, Budapest, 2012

Monográfia. Terjedelem: 318. Bibliográfia: 301-318. ISBN 9789632365541

- A szerző a Budapesti Történeti Múzeum Kiscelli Múzeumának muzeológusa. A mü a szerző doktori disszertációjának átdolgozott változata. A könyv arra igyekszik rávilágítani, hogy a címben megjelölt időszakban hogyan jelent meg a modern nagyvárosi bünözés. A vizsgálódás középpontjában annak bemutatása áll, hogy Budapest társadalmának egyes csoportjai hogyan látták a bünözés problémáját a századfordulón, különös tekintettel azon büntípusokra, amelyeket a szerző öszszefoglalóan a „hétköznapi bünözés” fogalmával jellemez. A kötet két nagy részre osztható, mely részek három-három fejezet tartalmaznak. Az első nagy egység a bünözésnek a tudományos munkák eredményeként kirajzolódó képét mutatja be. A második részben megismerheti az olvasó, hogy hogyan vélekedtek a hétköznapi emberek a kor bűnözéséről. A mű megírásában számos írott és levéltári forrás állt a szerző rendelkezésére, melyet jól mutat a könyv végén található terjedelmes bibliográfia. (G. Á.) 
- Tanulmányok Dr.Dr.h.c. Horváth Tibor professzor emeritus 85. születésnapja tiszteletére

Róth Erika (szerk.)

(Sorozat: Bünügyi tudományos közlemények, ISSN 1586-5304; 9.)

Bíbor, Miskolc, 2012

Tanulmánykötet. Terjedelem: 211. Bibliográfia a lábjegyzetekben és az egyes fejezetek végén. ISBN 9789639988415

- A szerzők egyetemi oktatók, kötetükkel a 85 éves Horváth Tibor professor emeritust köszöntik. Amellett, hogy ismertetik az ünnepelt szerepét a bünügyi tudományok fejlesztésében és oktatásában, a tanulmánykötetben megjelent értekezések a kriminológia és a büntetőjog tárgykörében születtek, többek között a bizonyítás nemzetközi sajátosságait, a női- és gazdasági bünözést, a közérdekủ munka büntetését, az Európai Unió költségvetésének büntetőjogi védelmét, valamint a bünügyi nyilvántartások rendszerét érintve. (F. P. P.)

- A gyermek és a bün. Tanulmányok a gyermekvédelem, a gyermek mint áldozat és a gyermekbünözés témaköréböl

Sipos László

(Sorozat: Egészségügyi kari jegyzetek; 16.)

Debreceni Egyetemi Kiadó, Debrecen, 2012

Egyetemi jegyzet. Terjedelem: 163. Bibliográfia a jegyzetekben. ISBN 9789633182710

- Az író egyetemi oktató, ügyész. A kötet középpontjában a gyermek mint áldozat és a gyermek mint bünelkövető áll. A gyermekbünözés problémája olyan terület, amely metszete a kriminológiának, a viktimológiának és a gyermekvédelemnek. A jegyzet betekintést ad a fiatalkorúak büntetőjogába, a fiatalkorúakkal szembeni eljárással és az alkalmazható szankciókkal kapcsolatos szabályok sajátosságaiba. (G. Á.)

- Új Büntető törvénykönyv: 2012. évi C. törvény a Büntető törvénykönyvröl

Szilner György (szerk.)

Novissima, Budapest, 2012

Jogszabálygyüjtemény. Terjedelem: 141. Bibliográfia nincs.

ISBN 9786155175442 (F. F.)

- Halálbüntetés pró és kontra

TótH J. Zoltán

HVG-ORAC, Budapest, 2012

Monográfia. Terjedelem: 291. Bibliográfia: 275-291. ISBN 9789632581774

- A szerző egyetemi oktató, a vizsgált témát 2003 óta kutatja. A könyv a 2008-ban megjelent „A halálbüntetés filozófiája és kortárs jogelméleti kérdései” címmel íródott monográfia bővített változata. Az írás elfogulatlan a halálbüntetés kérdését illetően, a szerző nem foglal állást, inkább a teljesség igényével igyekszik bemutatni a két oldal képviselőinek érveit. Az első rész a filozófiai érveket részletezi, a második pedig a modern elméleti vitákat mutatja be. Olvasmányossá teszi a könyvet az a megoldás, hogy a szembenálló álláspontok melletti érveket párbe- 
szédszerü formában ismerteti. Segíti a témában történő elmélyülést az olvasó számára az írásban található számos példa és tényadat, továbbá a könyv végén található függelék. (G. Á.)

- Büntetőjogi jogszabálygyüjtemény

[közread.] Károli Gáspár Református Egyetem Állam- és Jogtudományi Kar (Sorozat: Werbőczy-sorozat, ISSN 2062-2538)

Patrocinium, Budapest, 2012

Jogszabálygyüjtemény. Terjedelem: 174. Bibliográfia nincs. ISBN 9786155107467

- A könyv a 2012. február 1-jétöl hatályos büntetőjogi jogszabályi rendelkezéseket tartalmazza egységes szerkezetben a 2012. március 1. napján hatályba lépő rendelkezésekkel. Három jogszabályt közöl: a Büntető Törvénykönyvröl szóló 1978. évi IV. törvényt, a Büntető Törvénykönyvröl szóló 1978. évi IV. törvény hatálybaléptetéséről és végrehajtásáról szóló 1979. évi 5. törvényerejű rendeletet, valamint a 2001. évi CIV. törvényt a jogi személlyel szemben alkalmazható büntetőjogi intézkedésekről. A jogszabályok szövegét a vonatkozó büntető jogegységi határozatok, büntető elvi döntések, valamint kollégiumi állásfoglalások egészítik ki. (F. P. P.)

\section{EURÓPAI JOG, NEMZETKÖZI JOG}

- Reflections on European Public Prosecutor's Office. Effect of the economic crisis on the work and structure of the Prosecution Services and on the training of prosecutors in the European Union. $5^{\text {th }}$ Meeting Network of the Prosecutors General of the European Union, 24-26 May 2012

Gerencsér Balázs Szabolcs (szerk.)

Office of the Prosecutor General of Hungary, Budapest, 2012

Konferencia-kiadvány. Terjedelem: 112. Bibliográfia nincs. ISBN 9789630847582

- A kötet a 2012 tavaszán Budapesten rendezett, az Európai Unió tagállamai legfelsőbb bíróságai mellett működő legfőbb ügyészek vagy e tisztségnek megfelelő intézmények hálózatának 5. plenáris ülése és ehhez kapcsolódóan „A gazdasági válság hatása az ügyészségek munkájára, szervezetére és az ügyészek képzésére az Európai Unióban" címmel, angol nyelven megrendezett konferencia írásos anyagát tartalmazza. Az előadók között 16 uniós tagállam legfőbb ügyészségének képviselői és az EUROJUST elnöke is szerepeltek. A kötet tartalmazza a plenáris ülés résztvevői által a konferencia végén elfogadott közös nyilatkozatot is. (F. F.)

- EU-SCHOLA: Tanári kézikönyv az Európai Unióról

Greksza Veronika-Mohay Ágoston (szerk.)

(Sorozat: Studia Europaea 2012, ISSN 2062-5049)

PTE ÁJK Európa Központ-Publikon, Pécs, 2012

Kézikönyv. Terjedelem: 150. Bibliográfia az egyes fejezetek elején.

ISBN 9786155001765 
- A szerzők a Pécsi Tudományegyetem ÁJK oktatói, illetőleg PhD hallgatói. 2012ben az EU által támogatott EU-SCHOLA című projektjük célja az volt, hogy a közoktatásban résztvevő diákok és tanárok számára kézzelfoghatóbbá, ismertebbé tegyék az EU tevékenységeit. Jelen kötet e projekt keretében készült, így a speciális célközönségre tekintettel a hasonló tankönyvekhez képest némileg eltérő módszerrel tekinti át az alapvető uniós ismereteket. Viszonylag röviden ismerteti az intézményeket és a közös politikákat, de külön fejezetben foglalkozik diákok mobilitásával és az egész életen át tartó tanulás programjával, és bemutatja az uniós adatbázisokat, egyéb információforrásokat is. A kötethez interneten elérhető munkafüzet is kapcsolódott, amelynek weboldala sajnos már nem müködik. (F. F.)

\section{- Az oktatás az Európai Unióban: tanulás és együttmüködés}

HALÁsz Gábor

(Sorozat: Oktatás és társadalom, ISSN 2060-0194; 11.)

Új Mandátum, Budapest, 2012

Monográfia. Terjedelem: 376. Bibliográfia: 340-356. és a lábjegyzetekben. ISBN 9789632870533

- A szerző az ELTE Pedagógiai és Pszichológiai Karának egyetemi tanára. Kötetében az Európai Unió egyre jelentősebbé váló szakpolitikáját, az oktatáspolitikát vizsgálja. A kutatás, amely ugyan elsődlegesen oktatáspolitikai szempontú, a jogtudomány müvelői számára is hasznos lehet, hiszen egy meghatározott ágazatban vizsgálja az integrációs folyamatok összefüggéseit, alakulását. Ennek megfelelöen a kötet bemutatja az oktatáspolitika fejlödését, a mögöttes indokokat, az uniós szerepvállalást egyes szakpolitikai területeken (felsőoktatás, szakképzés, mobilitás növelése stb.), és az uniós és a nemzeti politikák összekapcsolódását. (F. F.)

- Vissza Európába - rögös úton: egy közremüködő szemével

HARGITA Árpádné

Gondolat, Budapest, 2012

Emlékírás. Terjedelem: 765. Bibliográfia: 645-650. ISBN 9789636934484

- Hargita Árpádné dr. Miklós Ágnes közgazdász, akinek pályafutása végigkísérte Magyarország európai uniós csatlakozási folyamatát. A különböző müfaji sajátosságokat ötvöző, terjedelmes munka ezt a folyamatot vizsgálja: a szerző saját élményei alapján csaknem fél évszázadot átfogó időszakot tekint át az 1960-as évektől a rendszerváltáson, a társulási szerződés létrehozásán és a csatlakozási tárgyalásokon át egészen a magyar soros uniós elnökségig. A mű több szempontból értékes: egyrészt tények sokaságát felsorakoztató, átfogó, valódi történeti munka Magyarország uniós csatlakozásának folyamatáról, másrészt a szerző személyes élményein keresztül bepillantást enged e folyamat mindennapjaiba. A kötet végén fényképgyüjtemény és a fontosabb jogi és politikai dokumentumok gyüjteménye található. (F. F.) 
- Az európai integráció alapjai (ideiglenes anyag)

Halmal Péter

Pannon Egyetemi Kiadó, Veszprém, 2012

Egyetemi jegyzet. Terjedelem: 126. Bibliográfia: 126. ISBN 9786155044694

- A szerző egyetemi tanár. Jelen kötet szándéka szerint ideiglenes tansegédletként szolgálhat az uniós ismeretek elsajátításához egy új, részletesebb tankönyv elkészültéig. Ezért valóban vázlatosan, de jól áttekinthető struktúrában, táblázatok, ábrák segítségével ismerteti az integráció történetét, az EU alapszerkezetét, intézményeit, a döntéshozatali eljárásokat, az uniós költségvetést, a közös kereskedelem- és versenypolitikát, a közös agrár- és strukturális politikát, illetve a monetáris unió lényegét. (F. F.)

- Handbook on the European Union

HoRVÁTH, Zoltán

Negyedik kiadás. HVG-ORAC, Budapest, 2011

Kézikönyv. Terjedelem: 707. Bibliográfia: 705-707. ISBN 9789632581460

- A 2011-ben nyolcadik kiadásban megjelent Kézikönyv az Európai Unióról címü kötet angol nyelvű változata sajnálatos módon kimaradt a 2011-es megjelenések bibliográfiájából (a magyar nyelvü kiadást ismertettük a 2013/1. számban). Az angol nyelvü kötet az átdolgozott magyar kiadáshoz hasonlóan már tartalmazza a Lisszaboni Szerződés újitásait és az utóbbi évek szakpolitikai változásait. Egyébként a kötet felépítése a korábbiakhoz igazodik: az első nagy szerkezeti egység az EU történetét, intézményrendszerét és működésének alapjait (jogalkotás, belső piaci jog, költségvetési jog) tárgyalja, a második nagy egység pedig a szakpolitikákkal (belső és külső politikák) foglalkozik. A kötetet, csakúgy, mint a magyar változatot, fogalomgyüjtemény zárja. (F. F.)

- Fight Against Terrorism and Protecting Human Rights: Utopia or Challenge? KaRdos KaPONYI, Elisabeth

Corvinus University of Budapest, Budapest, 2012 Monográfia. Terjedelem: 303. Bibliográfia: 299-302. ISBN 9789635034864

- A szerző a Budapesti Corvinus Egyetem tanára. A kötet hét fejezetben mutatja be a globális és regionális felelösség kérdését a nemzetközi terrorizmussal kapcsolatosan. A szerző célja megmutatni az emberi jogok és a terrorizmus elleni küzdelem közötti kapcsolódási pontokat és az ezek okozta nehézségeket. Így a kötet kitér az ENSZ és az Európa Tanács által folytatott gyakorlatra éppúgy, mint az Európai Unió keretein belül fejlődő stratégiára a terrorizmussal szembeni küzdelemben, továbbá az európai szervezetek és az ENSZ szervei közötti együttmüködésre ezen a területen. A szerző széles körben dolgoz fel nemzetközi szerződéseket és más kötelező és nem kötelező dokumentumokat, valamint kitér az Emberi Jogok Európai Bírósága vonatkozó gyakorlatára is. (K. Zs.) 
- Az Európai Unió gazdasági joga 1. A belső piac és a közös kereskedelempolitika Király Miklós (szerk.)

(Sorozat: ELTE jogi kari tankönyvek, ISSN 2060-6494; 5.)

ELTE Eötvös, Budapest, 2012

Tankönyv. Terjedelem: 289. Bibliográfia: 281-284. és a lábjegyzetekben. ISBN 9789633120323

- A szerkesztő és a szerzők az ELTE jogi karának uniós gazdasági joggal foglalkozó oktatói. A kétkötetes munka első kötete nyolc fejezetben tekinti át a négy gazdasági alapszabadság (az áruk, a személyek, a szolgáltatások és a tőke szabad áramlása) és az uniós kereskedelempolitika klasszikus tárgyköreit, valamint az újabb fejleményekre figyelemmel a Lisszaboni Szerződés vonatkozó rendelkezéseit és a belső piaci szabályozás tervezett módosításait. Az ismeretek könnyebb feldolgozását segíti az első bevezető fejezet, amely a fogalmi tisztázások mellett kitér a gazdasági integráció céljaira, és áttekinti a belső piaci jogforrások rendszerét. A munka második, uniós versenyjogot tárgyaló kötete 2013-ban jelent meg. (F. F.)

- Demokratikus átmenet a háborús büntettek árnyékában. A nemzetközi büntetőbíróságok és a tényfeltáró bizottságok szerepe az átmeneti igazságszolgáltatásban KIRs Eszter Bíbor, Miskolc, 2012 Monográfia. Terjedelem: 310. Bibliográfia: 277-308. és a lábjegyzetekben. ISBN 9789639988347

- A szerző a Miskolci Egyetem oktatója, valamint az ENSZ ex-jugoszláv nemzetközi büntető törvényszékén a védelem képviseletének tagja. A monográfia a szerző doktori értekezésén alapul. A könyv a demokratikus átmenet igazságszolgáltatási törekvéseinek intézményi aspektusait vizsgálja. Az első rész a nemzetközi büntetőbírói fórumok szerepével foglalkozik az átmeneti igazságszolgáltatás rendszerében, míg a második rész a tényfeltáró és békéltető bizottságok intézményével kapcsolatos kérdéseket vizsgálja. A következő fejezetben a két intézmény mandátumának elhatárolását és azok összemosásának következményeit elemzi a szerző. A könyv utolsó része a két intézménytípus közötti kapcsolattal és az együttmüködés lehetőségével foglalkozik. A kötet kitér az egykori jugoszláv térségbeli, a dél-afrikai, a ruandai, a kelet-timori, a Sierra Leone-i és az ugandai átmeneti igazságszolgáltatási megoldásokra és azok tanulságaira is. (P. N.)

- A Magyar Honvédség közremüködése Koszovó válságkezelésében, 1999-2011 Kovács József-Rózsa Tibor (szerk.) (Sorozat: Katonák békében és missziókban, ISSN 2063-3106) Zrínyi, Budapest, 2012

Szakkönyv. Terjedelem: 229. Bibliográfia: 205-206. ISBN 9789633275429

- A könyv szerkesztői Kovács József altábornagy és Rózsa Tibor ezredes. A kötet a Magyar Honvédség szerepvállalását mutatja be a KFOR-misszióban 1999-töl 2011. december 31-ig (a könyv kéziratának lezárásáig). Tizennégy fejezetre tagolva ismerteti Koszovó történelmét, kulturális életét, vallását, majd a Magyar Hon- 
védség KFOR-misszióban betöltött szerepét, kitérve a szervezeti felépítésre, a feladatokra, tevékenységekre, a kihívásokra és az eredményekre. A függelékben a Koszovóhoz, illetőleg a magyar misszióhoz kapcsolódó anyagokat és jogi dokumentumokat találjuk. A könyv számos dokumentummal és színes fotóval illusztrálva mutatja be a missziós alakulatok müködését és mindennapi életét. (P. N.)

- A magyar menekültjog és menekültügy a rendszerváltozástól az Európai Unióba lépésig. Erkölcsi, politikai-filozófiai és jogi vizsgálódások

NAGY Boldizsár

Gondolat, Budapest, 2012

Monográfia. Terjedelem: 330. Bibliográfia: 295-312. ISBN 9789636934248

- A szerző a menekültjog és menekültügy témakörének nemzetközileg elismert szakértője, egyetemi oktató. A mü a szerző doktori disszertációján alapul. A kötet két nagy témakört ölel fel: a menekültek védelme mellett szóló érvek rendszerének elméleti kidolgozását, valamint az elméleti úton kialakított érvrendszer alkalmazását a magyar menekültügy és a magyar menekültjog történetére. Az elméleti fejezetek a deduktív elemzés módszerével a menekültek védelme mellett szóló érvek megtalálását tűzik ki célul, mely célhoz a szerző etikai, politikaelméleti, jogbölcseleti, gazdasági és szociológiai eszközöket is rendel. A kötet elsődleges források felhasználásával, nyilvános diskurzus elemzésével tárja az olvasó elé, miként alakult és hol tart jelenleg a menekültügy területének szabályozása Magyarországon. (Be. A.)

\section{- Európai uniós ismeretek}

NagY Zsuzsanna-BÉResné MÁrtha Bernadett

Nyíregyházi Főiskola-Bessenyei Kiadó, Nyíregyháza, 2012

Főiskolai jegyzet. Terjedelem: 137. Bibliográfia: 129-134. ISBN 9786155097553

- A szerzők főiskolai oktatók. Az uniós ismeretekkel foglalkozó főiskolai kurzusok háttéranyagául szolgáló kötetben vázlatosan áttekintik az EU müködésére vonatkozó alapvető ismereteket, így röviden foglalkoznak a jog- és intézményrendszerrel, a költségvetéssel és a korábbi II. és III. pillérrel és néhány szakpolitikával. A kötet a legrészletesebben a közös agrárpolitikát ismerteti, amelynek magyarországi alkalmazására is kitér. Az utolsó fejezet a társfinanszírozású programokat (ISPA, PHARE, SAPARD) tekinti át. (F. F.)

- EU-jog

Osztovits András (szerk.)

HVG-ORAC, Budapest, 2012

Tankönyv. Terjedelem: 573 . Bibliográfia az egyes fejezetek végén.

ISBN 9789632581729

- A tankönyv szerzői négy jogi kar (KRE, ME, PPKE, SZE) Európa-jogot oktató szakemberei, a szerkesztő a KRE ÁJK tanszékvezetője. A szerzők szándéka szerint a kötet az uniós jog „esszenciáját” tartalmazza, azaz az első nagy egységben a jog- és intézményrendszer bemutatását (a klasszikus témakörök mellett külön fejezetben tárgyalva például az uniós polgárságot és a tagállamok kötelezettsé- 
geit az uniós jog érvényesülése érdekében), a második nagy egységben pedig a belső piaci jogot (egy önálló bevezető fejezetben áttekintve a négy alapszabadság közös jellemzőit is) és az uniós versenyjogot. A tankönyvben szereplö, igen aprólékosan tárgyalt témakörök elsajátítását ábrák, keretes kiemelések segítik. (F. F.)

- Recent Developments in European and Hungarian Competition Law Osztovits, András (szerk.) (Sorozat: Acta Caroliensia Conventorum Scientiarum luridico-Politicarum, ISSN 2063-4757; 1.)

KRE ÁJK, Budapest, 2012

Tanulmánykötet. Terjedelem: 88. Bibliográfia a jegyzetekben. ISBN 9789639808355

- A szerzők egyetemi oktatók. A kötet tanulmányai az uniós és a magyar versenyjog egyes kérdéseit járják körül. Grad-Gyenge Anikó az EU Bíróság 2008-as, szerzői jogokat érintő döntésével, Miskolczi Bodnár Péter és Osztovits András a versenyjogi szabályok megsértésével okozott kár és kártérítés kérdésével, Szuchy Róbert a villamos energia piacon tapasztalható verseny és állami támogatások témájával, Tóth András pedig a kisebbségi tulajdonszerzés versenyjogi aspektusaival foglalkozik. (F. F.)

- A nemzetközi környezetjog aktuális kihívásai

Raisz Anikó (szerk.)

Miskolci Egyetem, Miskolc, 2012

Konferenciakötet. Terjedelem: 220. Bibliográfia a lábjegyzetekben. ISBN 9789633580172

- A kötet a 2012. szeptember 21-22-én Miskolcon megrendezett nemzetközi konferencia résztvevöinek nemzetközi környezetjog témakörben készített tanulmányait gyűjti össze. A szerzők között a rendező Miskolci Egyetem mellett a DE, a PPKE, a PTE, a SZE és a SZTE jogi karainak oktatói, valamint európai parlamenti szakértők és a svájci fribourgi agrárintézet igazgatósági jogásza szerepelnek. A kötetben megjelenő tudományos művek a szük értelemben vett nemzetközi környezetjog mellett összehasonlító jogi, uniós és nemzeti jogi témakörben születtek. A két kivétellel magyar nyelvü írásokat tartalmazó kötet széleskörüen fedi le a nemzetközi környezetjog uniós, illetve hazai szabályozásának szerteágazó területét. (Be. A.)

- Az Európai Unió jogi fundamentumai

Szabó Marcel-Láncos Petra Lea-Gyeney Laura (szerk.)

Szent István Társulat, Budapest, 2012

Tankönyv. Terjedelem: 332. Bibliográfia a lábjegyzetekben.

ISBN 9789632773520

- A szerzők a PPKE Jog- és Államtudományi Karának oktatói. Kötetük klasszikus uniós jogi tankönyvnek tekinthetö: jól átlátható struktúrában, az esetjogot is ismertetve tekinti át az Európai Unió fejlődésének történetét, az uniós jogrendszert és 
intézményrendszert, a korábbi II. és III. pillért és a belső piaci jogot. Utóbbi fejezet keretes szövegként tartalmaz bírósági ítélet-részleteket, melyek között a klasszikusok mellett újabb esetekkel is találkozhatunk. A kötet az ismeretek áttekintését sajátos módszerrel segíti: számos kérdéskörhöz szakirodalmi forrásokból származó idézeteket, illetve internetes oldalakról származó aktuális híreket kapcsol. (F. F.)

\section{- Uniós szakpolitikák}

Szabó Marcel-Láncos Petra Lea-Gyeney Laura (szerk.)

Szent István Társulat, Budapest, 2012

Tankönyv. Terjedelem: 236. Bibliográfia a lábjegyzetekben. ISBN 9789632773988

- A szerzők a PPKE Jog- és Államtudományi Karának oktatói. Tankönyvük a szokásostól némileg eltérő struktúrában tekinti át az uniós politikákra vonatkozó főbb ismereteket: a közös fellépés egyes területeit négy nagy csoportba sorolja. Így elsőként az „alkotmányos jellegű politikák” között foglalkozik az EU és a vallás kapcsolatával, a családra vonatkozó rendelkezésekkel, illetve az uniós nyelvpolitikával. A klasszikus uniós politikákat a további három cím alatt találjuk: szabályozó jellegü politikák (pl. kereskedelempolitika, versenypolitika, szociális politika), elosztó jellegű politikák (mezőgazdasági politika) és újraelosztó jellegű politikák (kohéziós politika és fejlesztési politika). (F. F.)

- Essential EU competition law in charts

Tobler, Christa-Beglinger, Jacques-Geursen, Wessel

A 2011-es kiadás változatlan utánnyomása. HVG-ORAC, Budapest, 2012

Tankönyv. Terjedelem: 143. Bibliográfia nincs. ISBN 9789632581187 (F. F.)

- Essential EU law in text

Tobler, Christa-Beglinger, Jacques

A 2010-es kiadás változatlan utánnyomása. HVG-ORAC, Budapest, 2012

Tankönyv. Terjedelem: 122. Bibliográfia nincs. ISBN 9789632580876 (F. F.)

\section{JOGBÖLCSELET}

- Jogi terminológia és jogi alapfogalmak

ERDÖDY János

Negyedik, átdolgozott, bővített kiadás. Pázmány Press, Budapest, 2012

Egyetemi jegyzet. Terjedelem: 128. Bibliográfia: 10-11. és a lábjegyzetekben. ISBN 9789633080788

- A szerző egyetemi oktató. A kötet az először 2007-ben azonos címen megjelent mú negyedik, átdolgozott, bővített kiadása. A jegyzet elsősorban a nemzetközi igazgatási alapszakos hallgatók számára kíván hatékony segítséget nyújtani a római jogi gondolkodás alapjainak elsajátításához. A római jogrendszer legfontosabb jogintézményeit mutatja be, foglalkozik személyi joggal, családi joggal, va- 
lamint dologi joggal, öröklési és kötelmi joggal. A kötet a manapság használt jogi fogalmaink, illetőleg jogintézményeink eredetének ismertetésével kíván kiindulási pontként szolgálni azok jobb megértéséhez. (Zs. Zs.)

- Jog a személyközi viszonyokban. Az olasz jogfilozófia nyomdokain

FRIVALDSZKY János

(Sorozat: A Pázmány Péter Katolikus Egyetem Jog- és Államtudományi Karának könyvei, ISSN 1417-7285; Tanulmányok, ISSN 2061-7240; 12.)

Pázmány Press, Budapest, 2012

Monográfia. Terjedelem: 418. Bibliográfia: 410-416. és a lábjegyzetekben.

ISBN 9789633080726

- A szerző egyetemi oktató, kutató. A tanulmánykötet az alapvetően angolszász, valamint német hatást tükröző hazai jogelméleti diskurzustól eltérő jellegű, amelyben az olasz jogfilozófiai gondolkodás játszik központi szerepet. A kötetben a szerző javarészt az olasz jogelméleti gondolkodás eredményeit veszi górcső alá. Ennek keretében többek közt bemutatja az egyes fogalmakkal, illetve jogintézményekkel (jog, jogosultság, jogalanyiság, házasság, család) kapcsolatos jelentősebb olasz jogfilozófiai elemzéseket, elméleti eredményeket. Ezeken kívül néhány területen a szerző megvizsgálja egyes olasz jogfilozófusok elemzéseit Jhering, Fichte és Herbert Hart jogelméleti munkásságára vonatkozóan. (Zs. Zs.)

- A jogi gondolkodás mérföldkövei: a kezdetektöl a XIX. század végéig

Frivaldszky János (szerk.)

Szent István Társulat, Budapest, 2012

Tankönyv. Terjedelem: 303. Bibliográfia az egyes fejezetek végén. ISBN 9789632773438

- A szerzők egyetemi oktatók. Könyvük a jogi gondolkodás történetének fejlödését mutatja be a különböző korok jogi problémáin és az azokra megoldást kereső jogfilozófusok munkáin keresztül. A jogbölcseleti és jogtörténeti munkáikról híres szerzők új módon tárgyalják a jogi gondolkodók munkásságát. A tényeken túl bevezetnek a jogban történő okfejtés világába, feltárják a személytelennek hitt jogi gondolkodás korlátait, buktatóit a tény-fogalom-logika-gondolkodás emberi konstrukciójában. (Sz. E.)

- A politikai rend eredete. Az ember elötti időktöl a francia forradalomig FukuYama, Yosihiro Francis

Pető Márk ford.

Akadémiai, Budapest, 2012 Monográfia. Terjedelem: 688. Bibliográfia: 629-654. ISBN 9789630591935

- A könyv szerzője filozófus, politikai közgazdász, író, a nemzetközi politikai gazdaságtan professzora. A kötet a szerző 2011-ben megjelent The Origin of Political Order címü, a szakma által eddigi pályája csúcsának tartott kötetének első magyar nyelvü kiadása. A szerző a művet kétrészesre tervezte, melynek első kötete az ember előtti időszaktól a francia és az amerikai forradalom kitöréséig tárgyalja a politika történetét, azonban nem csak történeti, de filozófiai mélységben is. Az 
első rész az állam előtti állapotokról szól. A második rész az állam eredetétnek bemutatása a kínai, indiai és az oszmán birodalmakon, valamint a korai keresztény államokon keresztül. A harmadik rész témája a joguralom, míg a negyediké a felelős kormányzás. Az ötödik rész a politika fejlődéselméletének, illetve a mü második kötetének előrevetítése. (Ve. J.)

- A jog társadalmi küldetése az európai integráció és globalizáció korában Kondorosı Ferenc-VISEgRÁdy Antal

CompLex, Budapest, 2012

Kézikönyv. Terjedelem: 203. Bibliográfia a lábjegyzetekben.

ISBN 9789632952246

- A könyv a jog célját, a társadalomban betöltött szerepét, a jog és a társadalom egymásra kölcsönösen gyakorolt hatását vizsgálja. Ezen belül elemzi a jog hatékonyságának tartalmát és feltételeit, valamint azokat a társadalmi, gazdasági, politikai viszonyokat, kulturális hatásokat, pszichológiai tényezőket, melyek a jogra hatást gyakorolhatnak. A kiemelt (német, angol, francia, skandináv, kelet-európai, iszlám) jogi kultúrákkal e szempontok szerint foglalkozik. Külön részt szánnak a szerzők „az adott jogi politikai kultúra alapértékeinek gyűjtőneve” alatt az emberi jogok hierarchiája kialakulása és azok érvényesülése kérdésére különös tekintettel az európai uniós és nemzetközi jogi kodifikációra, valamint a nemzetközi bíráskodásra. (Sz. E.)

\section{- Standing Tall. Hommages à Csaba Varga}

Melkevik, Bjarne (szerk.)

Pázmány Press, Budapest, 2012

Tanulmánykötet. Terjedelem: 487. Bibliográfia a lábjegyzetekben.

ISBN 9789633080733

- A tanulmánykötet szerkesztője a kanadai Université Laval jogi karának profeszszora. Az általa szerkesztett angol nyelvű gyüjteményes mü a 70 . életévet betöltött Varga Csaba jogfilozófus professzor eddigi munkássága előtti tisztelgés. A tanulmányokat neves külföldi kutatók (többek között Zdenĕk Kühn, Patrick Glenn, Bernard S. Jackson) jegyzik. A kötet tematikája az ünnepelt tudományos pályafutásához igazodva rendkívül sokrétü: kimondottan jogfilozófiai tárgyú múveken kívül találkozunk bioetikai problémákat boncolgató szövegekkel, a jog kulturális-öszszehasonlító megközelítésével és a jogi informatika háttérelméleteivel is. (B. M.)

\section{- Jogpolitika: a jog depolitizálása és humanizálása}

SAmu Mihály

Harmadik, átdolgozott, bővített kiadás. Rejtjel, Budapest, 2012

Tankönyv. Terjedelem: 198. Bibliográfia a lábjegyzetekben. ISBN 9789637255830

- A szerző egyetemi oktató; könyvében elsősorban a jogi sztereotípiák, valamint a vulgáris és pozitivista jogi közgondolkodás meghaladására vállalkozik, hangsúlyozva, hogy a jog nem a napi politika, az államhatalom vagy a párturalom eszköze, hanem különálló alrendszerként értelmezendő egy demokráciában, azaz önálló rendeltetés és szerep betöltésére hivatott. A jogpolitika pedig a társadal- 
mi (köz-) politika közvetítésére szolgál, a jogi szabályozás szükségletei alapján (tekintettel a jogi szabályozás kivihetőségére és érvényesíthetőségére), illetve elősegíti a jogászi ethosz tudatosítását, a jogi kultúra értékeinek megvalósítását és modernizálását, valamint humanizálását. E munka a jogi-szakmai szemlélet megalapozása és fejlesztése okán nemcsak a joghallgatók, hanem gyakorlati jogászok és a közéleti érdeklődésü értelmiségiek figyelmére is számít.

\section{- Bevezetés a jog-és államtudományokba}

Szabó Miklós (szerk.)

(Sorozat: Prudentia luris, ISSN 1219-8471; 2.)

Ötödik, átdolgozott kiadás. Bíbor, Miskolc, 2012

Tankönyv. Terjedelem: 343. Bibliográfia a lábjegyzetekben és az egyes fejezetek végén. ISBN 9789639988460

- A szerzők egyetemi oktatók, kutatók. A kötet ötödik, átdolgozott kiadása az elöször 1995-ben megjelent münek. A tankönyv elsőéves joghallgatók számára készült, és a további jogi tanulmányok megalapozását szolgálja a jog és az állam fő jellemzőinek ismertetésén keresztül. A tizenkét fejezetből álló mủ bemutatja a jog alapvető fogalmait és jogintézményeit, mint például a jogforrás, a jogszabály, a jogrendszer, illetőleg a jogcsalád, továbbá tárgyalja a jogviszony és a jogi felelősség kérdését, valamint négy fejezetben kitér a modern állam jellemzőire is. A könyv végén fogalomtár is segíti az olvasót. (Zs. Zs.)

\section{- Jogi alapfogalmak}

Szabó Miklós

Harmadik, bővített és javított kiadás. Bíbor, Miskolc, 2012

Tankönyv. Terjedelem: 253. Bibliográfia a lábjegyzetekben. ISBN 9789639988477

- A szerző egyetemi oktató, kutató. A jog legalapvetőbb jellemzőit és fogalmait bemutató kötet a harmadik, bővített és javított kiadása az első alkalommal 2002-ben megjelent azonos című münek. A könyv hátterét esetenként egész bekezdések átvételével a szintén a szerző által szerkesztett „Bevezetés a jog- és államtudományokba" című mű nyújtja, de azzal ellentétben elsősorban nem joghallgatóknak, hanem a jogi karok más szakjainak hallgatói számára készült. A mủ első része a jog statikáját mutatja be, ennek keretében olyan alapfogalmakkal ismereti meg az olvasót, mint a jogszabály, a jogrendszer vagy éppen a jogcsalád. A következő szerkezeti egység a jog dinamikáját tárgyalja többek között a jogképződés és jogérvényesülés, illetőleg a jogviszony, valamint a jogi felelősség mibenlétének ismertetésével. A harmadik szerkezei egység pedig a jog struktúrája felé irányítja a figyelmet, ennek keretében a modern állam jellemző jegyeivel foglalkozik. A könyv legvégén fogalomtár is található. (Zs. Zs.) 
- Társadalmi-jogi kutatások

H. SZILÁGYI István-CSERne Péter-FEKETE Balázs

Szent István Társulat, Budapest, 2012

Egyetemi jegyzet. Terjedelem: 220. Bibliográfia a lábjegyzetekben. ISBN 9789633616352

- A szerzők egyetemi oktatók, kutatók. Az elsősorban joghallgatók számára készült jegyzet a Jogszociológia címú tantárgy elsajátításához kíván segítséget nyújtani. Tíz fejezete a jogszociológia legfontosabb kérdésköreit, elméleti problémáit vizsgálja. Ennek keretében kitér az jogszociológiai kutatások egyes módszertani kérdéseire, illetöleg a társadalmi-jogi kutatásokban alkalmazott jogfogalmakra és a jogösszehasonlítás egyes kérdéseire, továbbá vizsgálja a jog lélektani alapjait, a jog és a társadalmi struktúra összefüggéseit, valamint a jog és a gazdaság, illetőleg a jog és a politika kapcsolatát. A kötetet színesítik a szerkesztő által készített ábrák, a legvégén pedig függelék található, amely két jogszociológiai tárgyú tanulmányt tartalmaz. (Zs. Zs.)

- Államelmélet. Fejezetek és előadások az állam általános elmélete köréből Takács Péter-H. Szilágyi István-Fekete Balázs (szerk.)

Szent István Társulat, Budapest, 2012

Tankönyv. Terjedelem: 404. Bibliográfia a jegyzetekben. ISBN 9789632773506

- A szerzők (a szerkesztők mellett Győrfi Tamás és Péteri Zoltán) egyetemi oktatók, kutatók. A tankönyv első része történeti áttekintést nyújt az államelmélet mint tudomány és a modern állam kialakulására vonatkozóan. A második szerkezeti egységben az állam általános sajátosságait ismerheti meg az olvasó, úgy mint az állam fogalma, területe, népessége, szervezete, államhatalom. A mü utolsó harmadában olyan kérdések kerülnek tárgyalásra, mint például a demokrácia, az autoritás, a legitimitás egyes vetületei, továbbá az államnak a társadalommal és a politikai rendszerrel való összefüggései. (Zs. Zs.)

\section{- The Paradigms of Legal Thinking}

VARGa Csaba

(Sorozat: Philosophiae luris, ISSN 1218-0610)

Második, bővített kiadás. Szent István Társulat, Budapest, 2012

Monográfia. Terjedelem: 418. Bibliográfia a lábjegyzetekben.

ISBN 9789632772998

- A szerző egyetemi oktató, kutató. A könyv az angol nyelvű fordítása a szerző 2004-ben magyar nyelven megjelent $A$ jogi gondolkodás paradigmái címú munkájának és az 1999-es angol nyelvű kiadás bővített változata. A hét fejezetből álló müben a szerző igyekszik közelebb vinni az olvasót mindazon paradigmák megértéséhez, amelyek jogfelfogásunk, jogi gondolkodásunk alapjait megszabják. A szerző többek között bemutatja a jogi, a geometriai és az általános emberi gondolkodás fejlődéstörténetét, azok módszertani irányait, elemzi a jogi gondolkodás paradigmáit, valamint foglalkozik jelentéselmélettel is. A mü függeléket is tartalmaz, amelyben a szerző öt, már korábban megjelent tanulmányát olvashatjuk. A kötet elektronikusan teljes terjedelmében elérhető a szerző saját honlapján. (Zs. Zs.) 
- The Place of Law in Lukács' World Concept

VARGa Csaba

Petrányi Judit-Eszenyi Sándor-Varga Csaba ford.

Második kiadás. Szent István Társulat, Budapest, 2012

Monográfia. Terjedelem: 220. Bibliográfia: 219-220. ISBN 9789632772844

- A kötet magyar nyelven először 1985-ben látott napvilágot $A$ jog helye Lukács György világképében címmel. A kutatás Lukács György egész életművét vizsgálja annak érdekében, hogy minél teljesebb képet adjon a filozófus, marxista gondolkodó joggal kapcsolatos nézeteiről a jog tagadásától a jog igenléséig, az eszményitől a valóságig vezető folyamatban. A könyv első része a fiatal Lukács joggal kapcsolatos első találkozásáról, annak müveire gyakorolt hatásáról számol be, majd azokról a tendenciákról, melyek a joggal kapcsolatos felfogását befolyásolták. Legnagyobb súllyal a gondolkodónak a jog filozófiai elemzése kapcsán felmerülő kérdések (legalitás-moralitás, természetjog-tételes jog) kapcsán alkotott nézőpontját ismerteti, részletesen elemezve ontológiai jogszemléletét. A kötet elektronikusan teljes terjedelmében elérhető a szerző saját honlapján. (Sz. E.)

- A természetjogról

Varga Csaba (szerk.)

Szent István Társulat, Budapest, 2012

Szöveggyűjtemény. Terjedelem: 334. Bibliográfia: 315-320. és a lábjegyzetekben ISBN 9789632773698

- A kötet Horváth Sándor Imre jogtudós, domonkos rendi szerzetes 1922 és 1949 között közzétett természetjogi tárgyú írásainak gyűjteményét tartalmazza. A szerző a kötetben közölt munkáiban foglakozik többek között a természetjog rendező szerepével, valamint a társadalmi átalakulásokkal való összefüggéseivel, illetve a természetjog egyedi és közösségi vonatkozásaival. A kötetben a haza és a hazaszeretet jogbölcseleti alapjait, a nemzeti és keresztény erkölcs viszonyát, továbbá a létjogot elemző szövegeket is olvashatunk. Ezeken kívül a szerző írásaiban vizsgálja Aquinói Szent Tamás állameszméjét és a tulajdonjoghoz való viszonyát. A kötet a szerkesztő által írt utószót tartalmaz. (Zs. Zs.)

\section{- A szívébe írva. A természetjog mint az emberi társadalom alapja} WALDSTEIN, Wolfgang

El Beheiri Nadja-Erdődy János-Radványi Anna ford. (Sorozat: Pázmány Könyvek, ISSN 1586-5746; 7.)

Szent István Társulat, Budapest, 2012

Monográfia. Terjedelem: 238. Bibliográfia a lábjegyzetekben.

ISBN 9789632773070

- Wolfgang Waldstein a Salzburgi Egyetem nyugalmazott római jogász profeszszora. A kötet ötvenéves kutatómunkájának szintézisét, a jelenkori természetjogi gondolkodás egy sajátos vonulatát tárja az olvasó elé. Az antik római jogászok gondolkodásának kutatása során ugyanis egy önálló jogelméleti módszert dolgozott ki, egy modern természetjogot, amelyet egy „össz-európai jogi hagyományból” vezet le. Példái és érvelése alapján azonban könyve nemcsak az elméleti 
jogászokhoz, hanem a tételes joggal foglalkozó, gyakorlati szakemberekhez is szól. llyen összefüggésekbe enged bepillantást a házasság, a család vagy a tulajdonhoz való jog megközelítése révén. A kötet mélyreható elemzései nem könnyítették meg a fordítók munkáját, a magyar szöveg azonban a terminológiai különbségek ellenére kifogástalan gördülékenységgel ülteti át az eredeti gondolatokat, saját jegyzetekkel is segítve a megértést. (B. J.)

\section{JOGTÖRTÉNET}

- A politikai igazságszolgáltatás a II. világháború utáni Budapesten

Barna lldikó-Petö Andrea

Gondolat, Budapest, 2012

Monográfia. Terjedelem: 140. Bibliográfia: 137-140. ISBN 9789636934491

- A szerzők szociológus egyetemi oktatók: Barna lldikó az ELTE Társadalomtudományi Kar Társadalomkutatások Módszertana tanszékének adjunktusa, Pető Andrea a Közép-Európai Egyetem Társadalmi Nemek Tanszékének docense. A könyv alapvetően történelmi, sőt, társadalomstatisztikai (saját megfogalmazásuk szerint kvantitatív társadalomkutatás), nem pedig jogtörténeti megközelítésū, és kifejezetten csak 1945-töl 1949-ig tárgyalja a népbíróságok müködését. A szerzők a kb. huszonkétezer aktából reprezentatív, ötszáz fös mintát választottak, és ezeket dolgozták fel. A kötetböl bőséges adathalmaz alapján kap képet az olvasó a II. világháború után nemzetközi kötelezettségből felállított népbíróságok müködéséröl, a perek típusairól, az ítéletek csoportjairól és arányáról. A kötet legérdekesebb fejezetei a nők eljárás alá vonását, a női nem eljárásbeli szerepét, valamint a zsidó identitás és a népbírósági tárgyalások lehetséges összefüggéseit vizsgálják. (B. J.)

- Állami legitimációs eljárások és államföi jogkör 1867-1918 között

BeKe-Martos Judit

Kossuth, Budapest, 2012

Monográfia. Terjedelem: 296. Bibliográfia: 273-292. ISBN 9789630974196

- A szerző egyetemi oktató. Könyve alapjául PhD doktori értekezése szolgált, amelyet 2011 tavaszán sikeresen védett meg az ELTE Magyar Jogtörténeti Tanszékén, Mezey Barna témavezetése mellett. A könyv tulajdonképpen az alcímében megjelölt tartalmat fedi, hiszen tárgya az amerikai köztársasági és a magyar monarchikus államfői hatalomátruházási processzusok és a ceremoniális legitimáció összehasonlító jogtörténeti elemzése. Elsősorban azt vizsgálja, hogy hogyan, mitöl válik az államfő államfővé. A monarchikus és a köztársasági berendezkedés különbségeinek bemutatása mellett azt is megkísérli, hogy a történelmi esettanulmányokat egy általános közjogi modellben foglalja össze, kiemelve a minden berendezkedésben elengedhetetlen elemeket. A tárgykör szorosan kapcsolódik az ELTE-n folyó jogi szimbólumokat feltáró-elemző kutatásokhoz, és újdonság-értékủ a hazai jogirodalomban, hiszen kézzelfogható közelségbe hozza és európai szempontrendszer szerint dolgozza fel az eredeti amerikai forrásokat. (B. J.) 
- Gazdasági típusú perek, különös tekintettel az FM-perre (1945-1953)

Cseszka Éva

(Sorozat: Pártok és politika/MTA-ELTE Pártok, Pártrendszerek, Parlamentarizmus Kutatócsoport, ISSN 1589-911X)

Gondolat, Budapest, 2012

Monográfia. Terjedelem: 199. Bibliográfia: 163-167. és a lábjegyzetekben.

ISBN 9789636933876

- A szerző történész, egyetemi oktató. Kötete, mely 2005-ben megvédett doktori disszertációján alapul, a Rákosi-korszakban folyt koncepciós gazdasági pereket veszi górcső alá. Elsősorban azt vizsgálja, mennyire illeszkedtek a gazdasági perek a korszak nagy koncepciós pereinek sorába, mennyire lehet összehasonlítani az alkalmazott módszereket, az állambiztonsági szervek és az igazságszolgáltatás tevékenységét. A munka legrészletesebben a Földművelésügyi Minisztérium tisztviselöi ellen lefolytatott szabotázs-perrel foglalkozik, amely a szerző megállapítása szerint a katolikus egyház elleni harc egyik elemének is tekinthető. (F. Á.)

- Összehasonlító jogtörténet

Földi András (szerk.)

ELTE Eötvös, Budapest, 2012

Tankönyv. Terjedelem: 643. Bibliográfia az egyes fejezetek végén.

ISBN 9789633121306

- A szerzők az ELTE Római Jogi és Összehasonlító Jogtörténeti Tanszékének elsősorban nem római jogász munkatársai, akik a hazai jogtörténet-oktatásban jelenleg úttörő módon az egyetemes államtörténeti kurzust nem alapozó és elsösorban államtörténetre orientáló diszciplínaként közelítették meg, hanem dogmatikai rendszerbe foglalva, jogcsaládokhoz kapcsolódóan, értelmező-értékelő fejezetekben tárgyalják. A könyv egyetemi tankönyv, amelynek mintáit mindenekelött a német jogtörténet-tudományban lehet keresni. A tankönyvet a dogmatikai tagolás uralja, amelyet a kronológiai rend egészít ki: a közjogi jogintézmények után az egyes korszakokban és jogcsaládokban a büntetöjogot, majd a magánjogot ismertető részek következnek. Újszerủ szemlélete érdekessé, alapos feldolgozásmódja hasznossá teszi a tekintélyes könyvet a mélyebb történeti ismeretekre vágyó, összefüggésekre is kíváncsi olvasók számára. (B. J.)

- A megélt kor. Egy 20. századi oralhistory Ádám Antal és Rezsőházy Rudolf életútja alapján

Herger Csabáné (szerk.)

PTE ÁJK, Pécs, 2012

Interjúkötet. Terjedelem: 109. Bibliográfia nincs. ISBN 9789636425036

- A szerző egyetemi oktató, jogtörténész, aki - kissé eltávolodva saját szakterülete munkamódszerétöl - arra vállalkozott, hogy a 20. század történelmét személyes sorsokon keresztül ábrázolja, így árnyalja az olvasó történelemfogalmát. A történelem két értelmezője Ádám Antal pécsi alkotmányjogász professor emeritus, és Rezsőházy Rudolf történész professzor, a leuveni katolikus egyetem tanára, a PPKE díszdoktora. A beszélgetőpartner kérdései időben és tárgyukat tekintve is 
a két interjúalany életútjához igazodnak, a Horthy érával kezdődnek és átnyúlnak az ezredfordulón. A személyiségek életén keresztül a 20. század sajátos, szubjektív korrajza rajzolódik ki. Bár a kérdések sokszor jogi vonatkozásúak, maga a kötet nem jogtudományi munka. (B. J.)

- Szerzők, kiadók, kalózok. A szellemi alkotások védelmének kialakulása Európában JAKAB Éva

(Sorozat: Értekezések a jogtudomány köréből, ISSN 2062-9222)

Akadémiai, Budapest, 2012

Monográfia. Terjedelem: 204. Bibliográfia: 157-162. ISBN 9789630592727

- A szerző egyetemi oktató. Célja a szellemi termék és alkotója közötti viszony értelmezése a 16-19. századi dogmatikai irányzatok tükrében. A szellemi alkotások köréből a szerzői jogfejlődésre fókuszál, különös hangsúlyt fektetve az angol és német jogfilozófia eredményeire. A könyv alapjául 2011-ben az Oxfordi Egyetemen végzett kutatómunka szolgált, amely lehetővé tette számos 18-19. századi jogtudós munkáinak eredeti vizsgálatát. A szellemi alkotások védelmére vonatkozó szabályozástörténetet egy eszme- és kultúrtörténeti közegben helyezte el a szerző, amelyet a könyv tagolásában is kifejezésre juttatott. Az eredeti forrásközlések és esetismertetések a témában nem jártas olvasó számára is olvasmányossá teszik a könyvet, amely újabb hasznos segítség a szerzői jogi szabályozástörténet feltárásához. (P. L.)

- Magyaróvár tanácsának törvénykezési jegyzőkönyvei az 1581-1582. években = Rats- und Gerichtsprokoll des Marktfleckens Ungarisch Altenburg 1581-1582

KenYeREs István-D. SzaKÁcs Anita-MiHÁLy Ferenc

(Sorozat: Győr-Moson-Sopron Megye Győri Levéltára kiadványa, ISSN 1416-8146) Győr-Moson-Sopron Megye Győri Levéltára, Győr, 2012

Forráskiadás. Terjedelem: 160. Bibliográfia: a jegyzetekben.

ISBN 9789637228315

- A szerzők levéltárosok. Kenyeres István, Budapest Főváros Levéltárának főigazgató-helyettese írta a könyv bevezető tanulmányát. Mellette a könyv szerzői Szakács Anita, a megyei levéltár fölevéltárosa és Mihály Ferenc, Magyaróvár nyugalmazott levéltárosa. Szakács Anita a források értékelését végezte, Mihály Ferenc pedig jelentős teljesítménnyel lefordította a jegyzőkönyvek latin szövegeit. (B. J.)

- A Magyar Királyi Csendőrség és a Szombathelyi III. Csendőrkerület igaz története 1867-1945

Kocsıs Tibor-Kocsıs Tibor Krisztián

Magánkiadás, Szombathely, 2012

Monográfia és forrásközlés. Terjedelem: 554. Bibliográfia: 403-408. és a jegyzetekben. ISBN 9789630860468

- A szerzők több mint nyolc év kutatómunka után, száz archív fotó és dokumentum segítségével mutatják be a csendőrség történetét. A csendőrség a közbiztonsági szolgálat teljesítésére rendelt, katonailag szervezett őrtest, mely Magyarországon az 1881. évi II. és III. törvény alapján 1882. január 1-jén kezdte meg müködését, 
egyik központja pedig Szombathely volt. A könyvböl megismerhetjük a csendörség ruházatát, fegyverzetét, kiképzését, és sok szombathelyi vonatkozású adatot is. Külön fejezet foglalkozik a szombathelyi gettóval, és a vitézi renddel. (B. J.)

- Az ügyvédi kamarák megszületése Magyarországon

Korsósné Delacasse Krisztina

(Sorozat: Institutiones Juris, ISSN 1218-9375; Dialóg Campus szakkönyvek, ISSN 1417-7986)

Dialóg Campus, Budapest-Pécs, 2012

Monográfia. Terjedelem: 191. Bibliográfia: 180-186. ISBN 9789639950801

- A szerző egyetemi oktató, e munkája a 2009 tavaszán megvédett doktori értekezésének átdolgozott változata. A könyv kifejezett szándéka igazolni, hogy az ügyvédi autonóm szervezeti struktúra kialakulása nem az 1874-es törvénynek köszönhető, hanem már a század elejétől voltak - jóllehet, más célzattal létrehozott - szakmai kamarák. A munka ezen önigazgatási törekvést kíséri nyomon a megjelenésétől a neoabszolutizmus időszakának „elkanyarodásán” és az ügyvédegyleteken keresztül a kamarai törvény megszületéséig és végrehajtásáig. A törvényalkotási folyamat értékelése mellett feldolgozza a Pécsi Ügyvédi Kamara müködési iratait is, különös tekintettel a szervezeti és hatásköri szabályokra. A könyvet különösen értékessé teszi a komplex feldolgozás igénye és az elsődleges, levéltári források használata. (B. J.)

\section{- A nyugdíjrendszer Magyarországon Mária Teréziától a második világháborúig} KozÁrI Monika

(Sorozat: Társadalombiztosítási Könyvtár, ISSN 2063-2479)

Gondolat, Budapest, 2012

Monográfia. Terjedelem: 366. Bibliográfia: 337-342. ISBN 9789636934590

- A szerző történész, a dualizmus korának elismert kutatója. Új könyvében, amelyen több mint tíz évig dolgozott, a feltárt levéltári források alapján az állami nyugdíjszabályok évszázadokon átívelő fejlődését mutatja be (ezáltal valójában a legkorábbi szabályok hihetetlen időtállóságát igazolja). Cáfolja, hogy a végkielégítés, a nyugdíjminimum vagy a negyven éves szolgálati viszony napjaink találmánya volna, hiszen bemutatja, hogy már Mária Terézia és fia, II. József is fejlett nyugdíjazási szabályokat rögzített a tisztviselők egy csoportja részére. A magyar nyugdíjbiztosítás és -szabályozás története mellett a könyv a nemzetközi gyakorlatot is felvillantja, megismertetve az olvasót a különböző társadalombiztosítási rendszerekkel. A kötet végén szereplő táblázatok önálló elemzésekre is lehetőséget adnak az olvasónak. A történettudomány müvelöje bizony a társadalombiztosítási szakembereknek, szakjogászoknak is sok újat tud mondani. (B. J.)

- Aktuelle Aspekte der rechtshistorischen Forschung Mezey, Barna (szerk.)

(Sorozat: Junge Ungarische Rechtshistoriker, ISSN 1789-1036; 6.)

ELTE ÁJK Magyar Jogtörténeti Tanszék, Budapest, 2012

Konferenciakötet. Terjedelem: 158. Bibliográfia: a fejezetek végén. ISBN nincs. 
- A szerzők a Budapesten, 2011. december 15-én tartott nemzetközi doktoranduszkonferencia résztvevői. Hat ország fiatal kutatóinak összesen tíz tanulmánya szerepel a kötetben, válogatást adva a jogtörténeti kutatások aktuális irányairól. A tanulmányok alapján megállapítható, hogy a német nyelvű jogtörténeti kutatások döntő iránya a legújabb kor: a tanulmányok döntően XX. századi tárgyköröket érintenek (pl. Richeson tiszteletes esete, a tettes és áldozat közötti mediáció, állam és egyház viszonyrendszere a két világháború között, a második világháborút követő időszak különleges jogi jelenségei). Emellett fajsúlyosan van jelen a XIX. századi magánjogi dogmatika (a házassági vagyonjog fejlődése, a történeti jogi iskola befolyása a magánjogfejlődésre), és csak szűkebb körben a megelőző évszázadok - az is inkább jelenkori párhuzamok mentén (ítélkezés a boszorkányság és mágia miatt, igazságosság-felfogások). A hazai irodalomból tartalmilag Stipta István munkájához hasonlít a kortárs cseh jogtörténet korszakait és irányait bemutató tanulmány. (B. J.)

- Népi jogélet a Dél-Alföldön egy jogtörténeti és történeti forrás tükrében (17811821)

NAGY Janka Teodóra

(Sorozat: Documenta et Monographiae Universitatis Quinqueecclesiensis Faculta de Illyés Gyula Nominata, ISSN 2063-4404; 1.)

Pécsi Tudományegyetem Illyés Gyula Kar, Szekszárd, 2012

Monográfia. Terjedelem: 272. Bibliográfia: 253-267. ISBN 9789637305467

- A szerző föiskolai tanár, a jogi kultúrtörténet jogi néprajzzal foglalkozó területének elismert hazai kutatója, a Tárkány Szücs Ernő Jogi Kultúrtörténeti és Jogi Néprajzi Kutatócsoport elnöke. A könyv igazi jogi néprajzi csemege, hiszen jogesetek százait vonultatja fel, csoportosítja és értékeli, amelyek Makó mezővárosában fordultak elő és maradtak fenn jegyzőkönyvekben a XVIII-XIX. század fordulóján. A szimbolika és jogi kultúrtörténet szempontjából legérdekesebbek a vagyonjogi, házassági és a büntetőügyek, amelyekből a közel nyolcezer oldalnyi feldolgozott forrás bőséges merítési bázist szolgáltatott. A szerző kifejezett célja volt a források interdiszciplináris feldolgozása, a konkrét esetelemzések elvégzése, amelyek során a néprajz és a jogtörténet eszközrendszerét egyaránt felhasználta. Munkája a szakmai alaposság mellett az érdekesség, sokszínüség és újszerüség erejével is hat, ekként is fehívva magára a figyelmet. A könyv alapul szolgált a szerző 2013-ban lefolytatott habilitációjához is. (B. J.)

- Ügyészség, népügyészség, 20. század

PAPp Attila

Magánkiadás, Nagykanizsa, 2012

Monográfia. Terjedelem: 600. Bibliográfia: 591-597. és a jegyzetekben. ISBN 9789630844666

- A szerző 2010-ben végzett jogász, aki egyetemi évei alatt kezdett el a népbíróságok és népügyészségek témájával foglalkozni. A könyv közel ötéves kutatómunka eredménye. Első része az I. világháborúig tartó időszakot kíséri végig az ügyészségek szemszögéböl, és vizsgálja a társadalmi-politikai összefüggéseket. A 2. 
rész a két világháború közötti időszakról szól. A 3. rész nemzetközi jogi összefüggésekben vizsgálja azt, hogy a magyar háborús bűnösök felelősségre vonását hogyan lehetett viszonyítani a nemzetközi porondon való felelősségre vonáshoz, tehát a nemzetközi jogi környezetet vizsgálja teljes egészében. $A 4$. rész a népbíróssággal foglalkozik. Jóllehet, általában objektíven próbál vizsgálódni, de a szerző saját politikai véleményét is több helyen megosztja az olvasóval. A könyvet névmutató, életrajzi adatok és népbírósági fényképek egészítik ki. (B. J.)

- A szerződéstől való elállás az adásvétel mellékegyezményeinél a római jogban és továbbélése során

PÓKECZ KovÁcs Attila

PTE ÁJK, Pécs, 2012

Monográfia. Terjedelem: 279. Bibliográfia: 268-279. ISBN 9789636425050

- A szerző egyetemi oktató. A monográfia az elállási jog, mint egyoldalú jogosultság római jogi alapjait kutatja. A római jog nem ismerte a modern jogokban létező, általános elállás intézményét, amely a szerződés nem teljesítése miatt állhat be. Ez azonban nem jelentette azt, hogy az egyoldalú nyilatkozattal történő, és a szerződés keletkezésére visszaható hatályú megszüntetés is ismeretlen lett volna. A szerző ezt a jelenséget az adásvételi szerződés mellékegyezményei kapcsán vizsgálja, arra a kérdésre keresve a választ, hogy a lex commissoria, az in diem addictio és a pactum displicentiae intézményei megfeleltethetőek-e a modern civilisztikában ismert elállási jognak. A mellékegyezmények vizsgálata a könyv szerkezeti tagolásában is kifejezésre jut, melynek során a szerző a klasszikus római jogi forrásokon túl azok továbbélését és a modern magánjogi törvényekre gyakorolt hatását is vizsgálta. (P. L.)

- Szemelvények a tiszti ügyészek feladataiból

SzEnDREI Géza

Rejtjel, Budapest, 2012

Forráskiadás magyarázatokkal. Terjedelem: 120. Bibliográfia: 120.

ISBN 9789637255816

- A szerző nyugalmazott ügyész, az ELTE meghívott előadója. Fő kutatási témája az ügyészség története, amelyhez kapcsolódóan több munkája megjelent már nyomtatásban. Szemelvénygyüjteménye a tiszti ügyészséggel, mint a mai ügyészség előképével foglalkozik, annak rendi kori előzményeit mutatja be számos, föképp a Pest Megyei Levéltárban fellelt forrás értelmező közlése illetve - a könyv utolsó harmadában - fényképes megjelenítése révén. A munka értékes forrásul szolgál a tiszti ügyészség történetéhez, azonban a magyarázó szövegek sokszor nem egyeztethetők össze a jogtörténet jelenkori oktatásában és művelésében elfogadott tételekkel, magyarázatai, következtetései több esetben tévesek. (B. J.) 
- A magyar állampolgársági jog a 19. században

VARga Norbert

(Sorozat: Értekezések a jogtudomány köréböl, ISSN 2062-9222)

Akadémiai, Budapest, 2012

Monográfia. Terjedelem: 427. Bibliográfia: 343-384. ISBN 9789630592703

- A szerző a Szegedi Tudományegyetem oktatója. Könyve alapjául doktori értekezése szolgált, amelyet 2009 tavaszán védett meg Homoki-Nagy Mária és Stipta István témavezetésével. A szerző az első magyar állampolgársági törvényt (1879:L. tc.) és annak gyakorlatát mutatja be. A monográfia szerkezeti felépítésében is kifejezésre jut a jogszabály dogmatikus elemzése, és a 19. századi állampolgársági jogviszony teljes körü ismertetésének igénye. A törvény rendelkezéseit az elmélet és a gyakorlat oldaláról egyaránt vizsgálja, és nemzetközi összehasonlításban értékeli, kitérve a dualizmus közjogának sajátos összefüggéseire. Az állampolgársági jogviszony jellegével és alapelveivel több monográfia is foglakozott, amelyekhez képest a szerző komplex jogtörténeti megközelítése, és az elsődleges, levéltári források teljes körü feldolgozása és értelmezése mindenképp nóvumot jelent. (P. L.)

- Reformtörvények Magyarországon 1848-ban = The Acts of 1848 in Hungary Varga Norbert (szerk.)

(Sorozat: Fundamenta Fontium Juris, ISSN 2061-1609; 2.)

Pólay Elemér Alapítvány, Szeged, 2012

Forráskiadás. Terjedelem: 104. ISBN 9789639650893

- A szerző a Szegedi Tudományegyetem docense, jogtörténész. Munkája az 1848. évi áprilisi törvények szövegének kétnyelvű, angol és magyar változatát tartalmazza. Oktatási segédanyagként az Erasmus- illetve az idegen nyelvü PhD-képzések jogtörténeti kurzusaiban használható. (B. J.)

\section{KÖZIGAZGATÁSI JOG}

- Közigazgatási jog: Különös rész

Bencsik András (szerk.)

(Sorozat: Dialóg Campus tankönyvek, ISSN 1418-1274; Institutiones Juris, ISSN 1218-9375)

Dialóg Campus, Budapest-Pécs, 2012

Tankönyv. Terjedelem: 232. Bibliográfia: 230-232. és a lábjegyzetekben.

ISBN 9789639950825

- A szerkesztő egyetemi oktató. A kötet a közigazgatási jog oktatásának egyik legnehezebb témakörét, a közigazgatás egyes szakigazgatási területeinek sajátos intézményeit, valamint az adott terület müködési logikáját taglaló és összefoglaló ún. „Különös részt” tárgyalja. A tankönyv a különös rész átfogó összefüggései mellett bemutatja a leglényegesebb témaköröket, így a védelmi igazgatás egyes szektorait, valamint a gazdasági közigazgatás és a humán közszolgáltatások igazgatásának főbb területeit. A feldolgozást a szerzők szerint nagyban megnehezíti, hogy a különös rész anyaga hatalmas és erősen változékony. (B. A.) 
- Közérthetö közigazgatási hatósági eljárás. A Ket. szabályai egyszerüen-jogesetek, példák, közel 650 darab ellenörzö kérdés, feladat

Boros Anita

Harmadik, átdolgozott kiadás. CompLex, Budapest, 2012

Szakkönyv. Terjedelem: 362. Bibliográfia: 359-362. ISBN 9789632950921

- A szerző egyetemi oktató. A kötettel a közigazgatási eljárásjog, ezen belül a közigazgatási hatósági eljárásjog szerteágazó témakörének elsajátításához kíván segítséget nyújtani. A hatósági eljárás és szolgáltatás általános szabályairól szóló 2004. évi CXL. törvény (Ket.) rendelkezéseinek feldolgozása során nem csupán a jogszabályszöveg kommentálását végzi el, hanem példák és szemléletes jogesetek, valamint változatos önellenőrző feladatok segítségével igyekszik rávezetni az olvasót az eljárási normák legfontosabb céljaira, valamint a mögöttük meghúzódó alapvető jogalkotói szándékra. (B. A.)

- Válogatott európai önkormányzati modellek

Fábián Adrián (szerk.)

(Sorozat: Institutiones Juris, ISSN 1218-9375; Dialóg Campus tankönyvek, ISSN 1418-1274)

Dialóg Campus, Budapest-Pécs, 2012

Tankönyv. Terjedelem: 191. Bibliográfia az egyes fejezetek végén és a lábjegyzetekben. ISBN 9789639950818

- A szerzők egyetemi oktatók. Az összehasonlító jogi módszert alkalmazó kötet a Pécsi Tudományegyetemen készült a közigazgatási menedzser mesterszak oktatási igényeihez igazodva. A szerzők a mintául szolgáló európai országok (Franciaország, Nagy-Britannia, Németország, Spanyolország és Olaszország) helyi önkormányzati rendszereinek bemutatása mellett foglalkoznak az 1980-as és 1990-es években modellt választó országok, mint például Csehország, Horvátország vagy Magyarország megoldásaival is. (Á. Zs.)

- A rendőrség joga. Tanulmány a rendészeti igazgatásról

FinszTer Géza

Országos Rendőr-főkapitányság, Budapest, 2012

Monográfia. Terjedelem: 521. Bibliográfia: 508-521. ISBN 9789638883346

- A szerző egyetemi tanár, az MTA doktora, nyugállományú rendőr ezredes, munkája széleskörü elméleti és gyakorlati ismereteket ötvöz. Kötetében a rendészeti igazgatás komplex vizsgálatára vállalkozik: tíz fejezeten keresztül jut el a rendészet általános, elméleti kérdéseitöl a modern rendészet szabályozásáig. A szerző nagyfokú precizitással ismerteti meg az olvasót az egyes terminológiai elhatárolásokkal, a közigazgatás és rendészeti igazgatás egymáshoz való viszonyával, személyzeti és szervezeti kérdéseivel, a rendészet közhatalmi forrásaival. A kötet képet ad a rendészeti stratégiákról és az alkotmányos alapokról is. (B. A.) 
- Az önkormányzati törvény a gyakorlatban (Tanácsok, módszerek, alkalmazási technikák a törvény végrehajtásához)

GYERGYÁk Ferenc

(Sorozat: „Jegyzők Dokumentumtára”, ISSN 1219-9222; 38.; Közigazgatás a gyakorlatban, ISSN 1218-8018)

Közigazgatás Módszertani Bt., Pécs, 2012

Szakkönyv. Terjedelem: 338. Bibliográfia nincs. ISBN 9789638696588

- A szerző az Alkotmánybíróság főtanácsadója. A könyv Magyarország új önkormányzati kódexét, a 2011. évi CLXXXIX. törvényt (Mötv.) mutatja be, annak intézményeit ismerteti elméleti és gyakorlati szemszögből. A munka célja vállaltan az, hogy a törvény logikáját követve segítsen a jogalkotói szándék jobb megértésében, egyszersmind a praktikum oldaláról is értékelje az új és megújított intézményeket. Ennek megfelelően a kötet a jogszabályhelyek mellett megjeleníti a törvényhez füződő hivatalos indokolást, valamint az elméleti álláspontokat és a releváns bírósági gyakorlatot is. Miután az Mötv. hatálybalépése fokozatosan valósul meg, kifejezetten praktikus, hogy a szerző külön kiemeli, a törvény vonatkozó része mely időpontban lép hatályba. (B. A.)

\section{- Két konferencia a hatékony államról - a hatékony államért}

Hollán Miklós (szerk.)

Budapesti Corvinus Egyetem, Budapest, 2012

Konferenciakötet. Terjedelem: 178. Bibliográfia a jegyzetekben. ISBN 9789635034987

- A kötet a 2011. június 17-én és szeptember 30-án a BCE-n rendezett, tematikailag rendkívül gazdag két konferencián elhangzott előadások írásos változatát közli. Tekintettel arra, hogy a hatékonyságnak számos vetülete van, a kiadványban szereplő írásokat is a sokszínűség jellemzi: a humánpolitikától (Kis Norbert) a nemzetközi migrációs kérdéseken (Halász Iván) keresztül a befolyással üzérkedésig (Hollán Miklós) és az olaszországi közigazgatási reformig (Vizi Balázs) számos kérdés tárgyalására sor kerül benne. (B. A.)

- A közigazgatási hatósági eljárás

IVANCSICS Imre

PTE ÁJK, Pécs, 2012

Egyetemi jegyzet. Terjedelem: 306. Bibliográfia: 302-306. ISBN nincs.

- A szerző egyetemi oktató. A jegyzet a közigazgatási hatósági eljárás általános szabályait elméleti oldalról közelíti meg: a törvény felépítését követve bemutatja a közigazgatási aktusokat, a hatósági tevékenységek egyes fajtáit, és a szabályozási koncepciók elemzése alapján meghatározza a hatósági eljárás fogalmát. A történeti előzmények ismertetése után a magyar szabályozási modell jellemzőinek összefoglalásával magyarázza a törvényt. (V. B.) 
- Magyarország és a védelmi igazgatás rendszere: hagyomány és megújulás! Kiss Zoltán (szerk.)

HM Zrínyi Kommunikációs Szolgáltató Nonprofit Közhasznú Kft., Budapest, 2012 Kézikönyv. Terjedelem: 177. Bibliográfia a lábjegyzetekben. ISBN 9789633275405

- A szerzők egyetemi oktatók és gyakorlati szakemberek. A könyv a védelmi igazgatás megváltozott rendszerét mutatja be, kitérve a honvédelemre és a katasztrófavédelemre, ezek közigazgatásban betöltött szerepére. Részletesen szól az Alaptörvény és a sarkalatos törvények e területet érintő módosításairól, az egyes közigazgatási szereplök feladatairól, a mai viszonyoknak megfelelő térinformatikai és infokommunikációs eszközökröl. A kötetben található mellékletek a védelmi igazgatás rendszerét szereplők és feladatok szerint tekintik át. (V. B.)

- A köznevelési törvény: 1993-2011/2012

Madarász Hedvig (szerk.)

(Sorozat: Az oktatási jogszabályok változásai, ISSN 2063-3432; 2.)

CompLex, Budapest, 2012

Jogszabálygyüjtemény. Terjedelem: 303. Bibliográfia nincs.

ISBN 9789632950907

- A szerkesztő közoktatási szakember. A kötet három részre tagolódik. Az első rész összefoglalja a nemzeti köznevelésről szóló 2011. évi CXC. törvény föbb jellemzőit. A második rész ún. tükrös megoldással készült: párhuzamos szerkesztésben, két hasábban mutatja az új köznevelési törvény és a közoktatásról szóló 1993. évi LXXIX. törvény tartalmilag összefüggő szakaszait. A kiadvány harmadik része a köznevelési törvény indokolását tartalmazza. Mivel a törvénynek nincs hivatalos indokolása, a szerkesztő a törvényjavaslatok és módosító javaslatok indokolását használta fel. (L. V. Cs.)

- A Magyarország helyi önkormányzatairól szóló törvény magyarázata Nagy Marianna-Hoffman István (szerk.)

HVG-ORAC, Budapest, 2012

Kommentár. Terjedelem: 530. Bibliográfia: 520-523. ISBN 9789632581828

- A szerzők egyetemi oktatók. A kötet arra vállalkozik, hogy a 2012-ben - legalább részben - hatályba lépett, Magyarország helyi önkormányzatiról szóló törvényhez magyarázatot füzzön. A feladat azért jelentett nagy kihívást a szerzőknek, mert az Mötv. felhatalmazó rendelkezései alapján a végrehajtási szabályok jelentős része ekkor még nem született meg, illetve az alkalmazás során felmerülő problémákat is csak prognosztizálni lehetett. A kommentár ennek ellenére nem csupán a jogszabály szoros értelemben vett magyarázatát tartalmazza az egyes szakaszokhoz rendelve, hanem iránymutatást ad a várható problémákról és azok megoldási javaslatairól, valamint tárgyalja a vonatkozó bírósági gyakorlatot. (Á. Zs.) 
- Hatósági eljárásjog a közigazgatásban

Patyi András (szerk.)

(Sorozat: Institutiones Juris, ISSN 1218-9375; Dialóg Campus tankönyvek, ISSN 1418-1274)

Dialóg Campus, Budapest-Pécs, 2012

Tankönyv. Terjedelem: 654. Bibliográfia a lábjegyzetekben.

ISBN 9789639950870

- A szerzők egyetemi oktatók. A közigazgatási hatósági eljárás mint folyamatosan változó jogterület követése állandó készenlétet igényel mind a jogalkalmazóktól, mind az oktatóktól és a hallgatóktól. A kötetet a közigazgatási eljárás 2012-es állapotáról ad egy pillanatképet a 2009-ben megjelent kiadás átdolgozásával, átvezetve azon az Alaptörvény által hozott módosulásokat is. A könyv a közigazgatási jogi oktatás igényeit tartja szem előtt, így szisztematikusan, tudományos megalapozással dolgozza fel a Ket. egyes fejezeteit. (Á. Zs.)

- Általános közigazgatási jog (az Alaptörvény rendszerében)

PATYI András-VARga Zs. András

(Sorozat: Institutiones Juris, ISSN 1218-9375; Dialóg Campus tankönyvek, ISSN 1418-1274; Dialóg Campus szakkönyvek, ISSN 1417-7986)

Dialóg Campus, Budapest-Pécs, 2012

Tankönyv. Terjedelem: 351. Bibliográfia: 342-351. ISBN 9789639950863

- A szerzők egyetemi oktatók. A közigazgatási joganyag elmúlt évekbeli jelentős átalakítása által életre hívott tankönyv szerkezetileg három „könyvbe” rendezve ismerteti a közigazgatás és a közigazgatási jog alkotmányos meghatározottságát, a közigazgatási müködés jogi kérdéseit, valamint a magyar közigazgatás szervezetét. A szerzők sokéves oktatási tapasztalattal rendelkezve igyekeztek valóban világos és a hallgatók számára jól érthető tankönyvet készíteni. (B. A.)

- A pedagógusképzés jogi szabályozása, 1990-2010

RÁDLI Katalin

(Sorozat: Dokumentumok a pedagógusképzés történetéből)

ELTE Eötvös Kiadó, Budapest, 2012

Kézikönyv. Terjedelem: 462. Bibliográfia: 459-462. ISBN 9789633121252

- A szerző oktatáspolitikai szakember. Kötetében a vonatkozó jogi és egyéb dokumentumokon keresztül a pedagógusképzés rendszerváltástól 2010-ig terjedő időszakát dolgozza fel. Elsőként bemutatja az egységes tanárképzés 2002-ig tartó időszakát és követelményrendszerét, majd az ezt követő időszak újítását, az alap- és mesterképzés rendszerét, kimeneti követelményeit. Külön fejezet foglalkozik a gyógypedagógus-képzés, a szakmai tanárképzés és szakoktató képzés, valamint a tanító- és óvodapedagógus-képzés sajátosságaival, képzési követelményeivel, jogszabályi hátterével. (L. V. Cs.) 
- A jó kormányzásról. Elmélet és kihívások

Szigeti Szabolcs-Frivaldszky János (szerk.)

(Sorozat: Agóra, ISSN 1589-4584; 12.; Jezsuita könyvek, ISSN 2063-7896)

JTMR Faludi Ferenc Akadémia-Jezsuita Európa Iroda-OCIPE MagyarországL'Harmattan, Budapest, 2012

Tanulmánykötet. Terjedelem: 368. Bibliográfia a lábjegyzetekben és az egyes tanulmányok végén. ISBN 9789638014382

- A kötetben szereplő tanulmányok jelentős része a jó kormányzás és társadalompolitikai programok szelekciója témájában a Faludi Ferenc Akadémia által rendezett konferencián elhangzott előadások szerkesztett változata. A kötet öt nagyobb csoportba rendezve közöl elméleti és gyakorlati szemléletủ tanulmányokat az állam hatékonyságának növelése, a jó kormányzás erősítése témakörében. A közlemények foglalkoznak például a részvétel kérdéskörével, az átláthatóság és az elszámoltathatóság egyes aspektusaival, illetve a hatékonyság követelményeivel. (B. A.)

- Közigazgatási eljárás: 2004. évi CXL. törvény a közigazgatási hatósági eljárás és szolgáltatás általános szabályairól (2012. szeptember 20.)

Szilner György (szerk.)

Novissima, Budapest, 2012 Jogszabályközlés. Terjedelem: 97. Bibliográfia nincs. ISBN 9786155175527

- A kötet a címben szereplö törvény szerkesztett változatát és a vonatkozó bírói jogegységi határozatokat adja közre, külön jelölve a korábbi (2012. április 15.) kiadáshoz képest megváltozott részeket. (B. A.)

- Kommentár a köznevelési törvényhez

SzüDI János

CompLex, Budapest, 2012

Kommentár. Terjedelem: 396. Bibliográfia nincs. ISBN 9789632952383

- A szerző közoktatási szakember. A kiadvány a nemzeti köznevelésről szóló 2011. évi CXC. törvény magyarázatokkal ellátott szövegét adja közre. A paragrafusonkénti magyarázatok utalnak az Alaptörvényre és az egymáshoz kapcsolódó rendelkezésekre is, azonban nem minden esetben teljekörüek, mivel a kötet megjelenésekor egyes végrehajtási rendeletek még nem voltak ismertek. (L. V. Cs.)

- Európai közigazgatás

Torma András (szerk.)

Miskolci Egyetemi Kiadó, Miskolc, 2012

Tankönyv. Terjedelem: 257. Bibliográfia: 251-257. ISBN 9786155216350

- A szerzők egyetemi oktatók. A tankönyv célja a jogász, illetve a közigazgatási mesterképzésben résztvevő hallgatók megismertetése az Európai Unió szupranacionális szinten megvalósuló közigazgatásával. Ennek érdekében a kötet áttekinti az integráció legfontosabb közigazgatási aspektusait, az Európai Unió központi közigazgatását, a területi-helyi szintet, az európai ügynökségek sajátosságait, a központi szervek müködését, az uniós jogrendszer közigazgatási alapjait, végül 
pedig megadja az európai közigazgatás fogalmát. Mindezeken keresztül megismerhető az uniós döntések előkészítésének, részbeni meghozatalának és végrehajtásának szervezeti, személyzeti és eljárási háttere. (P. O.)

- A közigazgatási eljárás iratmintái

Varga Katalin (szerk.)

Átdolgozott kiadás. Pénzügyi Tájékoztató Iroda Kft., Hagyárosbörönd, 2012 Iratminta-gyüjtemény. Terjedelem: 383. Bibliográfia nincs. ISBN 9789639789227

- A közigazgatási gyakorlattal rendelkező szakemberek közremüködésével öszszeállított iratminta-gyüjtemény elsősorban önkormányzatok (és költségvetési szerveik) számára készült. A kiadvány külön foglalkozik a hatásköri, illetékességi kérdésekkel (pl. áttétel, eljárás megszüntetése), az elsőfokú eljáráshoz kapcsolódó döntésekkel (pl. az eljárás felfüggesztésével összefüggő esetek), a hatósági ellenőrzéssel (pl. értesítés, jegyzőkönyv), a jogorvoslatokkal (fellebbezés, újrafelvétel), a végrehajtással (pl. a végrehajtás felfüggesztése), valamint a költségmentességgel (pl. költségmentesség engedélyezése, visszavonása) kapcsolatos iratmintákkal. Az iratminták a Ket. 2012. február 1-jei állapotához igazodnak. (B. A.)

- Ombudsman, ügyész, magánjogi felelősség. Alternatív közigazgatási kontroll Magyarországon

VARGA Zs. András

(Sorozat: A Pázmány Péter Katolikus Egyetem Jog- és Államtudományi Karának könyvei, ISSN 1417-7285; Jogtudományi Monográfiák, ISSN 2061-5191; 3.)

Pázmány Press, Budapest, 2012

Monográfia. Terjedelem: 362. Bibliográfia: 325-362. ISBN 9789633080740

- A szerző egyetemi oktató. Könyvében a közigazgatási kontroll témakörével foglalkozik, annak alternatív eszközeire és szükségességük igazolására fókuszálva. Áttekinti a közigazgatási kontrolleszközökkel összefüggő legfontosabb magyar és külföldi közigazgatás-tudományi megközelítéseket és a kontrolleszközök dogmatikai alapjait, majd részletesen bemutatja a bírói, az ombudsmani típusú, valamint az ügyészségi kontroll jellemzöit. A kötet végén ötven pontban, tézisszerüen foglalja össze föbb megállapításait. A szerző feldolgoz számos alkotmánybírósági határozatot, bírósági döntést, az Emberi Jogok Európai Bíróságának több ítéletét, ombudsmani jelentéseket, valamint nemzetközi ajánlásokat is. (P. O.)

- Jogi adatbázisok és jogi forráskutatás. Gépek a jogban

ZöDI Zsolt

Gondolat, Budapest, 2012

Monográfia. Terjedelem: 224. Bibliográfia: 207-214. és a lábjegyzetekben. ISBN 9789636934637

- A szerző egyetemi oktató, az MTA JTI kutatója. Kötete PhD kutatásainak eredményét foglalja össze. Munkájában részletesen foglalkozik a számítógép használatához, mint a jogi forráskutatás eszközéhez kapcsolódó jogelméleti megfontolásokkal. A jogi adatbázisok történeti hátterének ismertetése kapcsán kitér az amerikai 
és európai példákra is. Bemutatja az általános adatbázisok és jogi adatbázisok közötti különbségeket, részletezi az utóbbi felépítésére vonatkozó jellemzőket, előtérbe helyezve a kutatás fázisait és a felmerülő problémákat. (V. B.)

\section{MUNKAJOG}

- Munkaviszonyok megszünése és megszüntetése

BANKó Zoltán-BenKED Ildikó-KÁRTYÁs Gábor-Kun Attila

Második, átdolgozott kiadás. Menedzser Praxis, Budapest, 2012

Kézikönyv, kapcsos borítóban, cserélhető lapokkal. Bibliográfia nincs. ISBN nincs. ISSN 1788-5442

- A szerzők egyetemi oktatók és gyakorló jogászok, a munkaviszony megszünése és különösen a megszüntetése körében e két kötetes kiadványban kívánnak segítséget nyújtani, elsősorban a munkáltatóknak, az eligazodáshoz. A megszünés és megszüntetés jogintézményeit számos példával, közérthetően, a gyakorlat bemutatásán keresztül igyekeznek ismertetni. A könyv az 1992. évi munka törvénykönyv rendelkezéseire, valamint az ahhoz kapcsolódó bírói gyakorlatra épül. Ezen túlmenően a szerzők foglalkoznak a megbízási és vállalkozási szerződés, mint munkavégzésre irányuló jogviszony - továbbá a közalkalmazotti jogviszony megszűnésével is. A kiadvány mellékletét képező $C D$ a napi gyakorlatot segítő iratmintákat tartalmazza. (B. K.)

- Munkajogi kézikönyv, 2012

BANKó Zoltán-Berke Gyula-KAJTÁR Edit-KIss György-KovÁcs Erika (Sorozat: Saldo szakkönyvsorozat, ISSN 2062-8218; Gazdálkodási kézikönyvek sorozat, ISSN 1788-3245)

Saldo, Budapest, 2012

Kézikönyv. Terjedelem: 395. Bibliográfia nincs. ISBN 9789636384333

- A szerzők egyetemi oktatók és gyakorló jogászok. Céljuk egy olyan kézikönyv elkészítése volt, amely a 2012. évi munka törvénykönyv (Mt.) szabályait mindenki számára könnyen érthető módon, de nem egy kommentár részletességével magyarázza meg. (A mủ a CompLex Kiadó gondozásában megjelent, A Munka Törvénykönyve magyarázata címmel megjelent kommentár kivonata.) A szerzők elsődleges szempontja a könyv megírása során az volt, hogy a foglalkoztatási gyakorlat mindennapjaiban a leggyakrabban hivatkozott jogszabályhelyekhez és annak változásaihoz füzött magyarázatok kerüljenek részletes ismertetésre. lly módon a mindennapi jogalkalmazás számára kívánnak segítséget nyújtani. A könyv szerkezete a törvény felépítését követi, $s$ az egyes rendelkezések magyarázatánál a szerzők kitérnek a vonatkozó uniós szabályokra, valamint a bírói gyakorlatra. (B. K.) 
- A kötelezö öregségi életjáradékok lehetséges modelljei

BANYÁR József

(Sorozat: Társadalombiztosítási könyvtár, ISSN 2063-2479)

Gondolat, Budapest, 2012

Monográfia. Terjedelem: 272. Bibliográfia: 263-272. ISBN 9789636934224

- A szerző közgazdász, oktató és gyakorlati szakember. A könyv a szerző azonos címü, 2011-es PhD értekezésének átdolgozott változata. A szerző célja a járadékszabályozási rendszerek és modellek lehetséges ellentmondásainak feltárása. Foglalkozik a járadékokkal kapcsolatos legfontosabb technikai kérdésekkel, a járadékok kalkulációjának elvi alapjaival, az egyes járadékfajták és életbiztosítások összefüggéseivel, illetve a kötelező öregségi nyugdíjjáradékok lehetséges modelljeivel. Bár a szerző elsősorban közgazdaságtani oldalról vizsgálja az öregségi életjáradékokat, a jogszabályi rendelkezések és közgazdaságtani vonatkozások átfogó elemzése révén a társadalombiztosítás területével foglalkozó jogászok számára is használható könyvröl van szó. (B. K.)

- Munkaügy a közoktatásban. Intézményvezetők munkaügyi kalauza

BÉRESNÉ DunAl Gyöngyi et al.

Raabe Tanácsadó és Kiadó Kft., Budapest, 2012

Kézikönyv kapcsos borítóban, cserélhető lapokkal. Bibliográfia nincs. ISBN nincs. ISSN 2063-4536

- A szerzők gyakorló jogászok. Az alapkönyv 2012-es kiadású, amelyben a jogszabályi változásokat a cserélhető lapok révén rendszeresen átvezetik. Elsősorban a 2012. évi munka törvénykönyvének, illetve a közalkalmazottakról szóló 1992. évi XXXIII. törvénynek (Kjt.) a közoktatásban alkalmazandó szabályait, illetve az ehhez kapcsolódó bírói gyakorlatot kívánják a szerzők bemutatni, s a gyakorlatban is alkalmazható tanácsokkal ellátni az érintetteket. A könyv összesen 6 , tematikusan építkező fejezetből áll, amelyek különösen a foglalkoztatást meghatározó jogszabályokról, a foglalkozatással kapcsolatos egyéb területekröl, a közoktatási intézményekben ellátandó munkáltatói feladatokról, valamint a bírósági gyakorlatról szólnak. A könyv a foglalkoztatással kapcsolatos iratmintákat is tartalmaz. (B. K.)

\section{- Az új munka törvénykönyve - munkavállalóknak}

BODNÁR Lilla

CompLex, Budapest, 2012

Szakkönyv. Terjedelem: 271. Bibliográfia nincs. ISBN 9789632952178

- A szerző egyetemi oktató, ügyvéd. Könyvében az új Mt. (2012. július 1.) valamenynyi rendelkezését ismerteti, ezen belül azonban hangsúlyosan jelennek meg azok a szabályok, amelyek a régi Mt.-hez (1992) képest jelentős változásokon mentek keresztül. A munkaviszony létesítésétől kezdve a munkaviszony tartalmán át egészen a munkaviszony megszünéséig valamennyi szabályt tárgyal. A szerző felhívja a figyelmet a megállapodások jelentős szerepére mind az individuális, mind a kollektív munkajogban. Kiemeli a jogszabály egyes pontjainak elemzésénél azt, hogy a munkavállaló előnyére és hátrányára hogyan lehet eltérni a munkaszerződéstől, illetve a kollektív szerződéstől. (D. D.) 
- A közalkalmazotti és közszolgálati jogviszony gyakorlati kézikönyve: az új törvényi előírások bemutatása, munkaügyi jogalkalmazás, esettanulmányok, szabályzatok DEÁk-EGYEd Annamária et al.

Második, átdolgozott kiadás. Menedzser Praxis, Budapest, 2012

Kézikönyv kapcsos borítóban, cserélhető lapokkal. Bibliográfia nincs. ISBN nincs. ISSN 2063-3971

- A szerzők gyakorló jogászok. A 2012. évi munka törvénykönyv hatálybalépésével szükségessé vált a munkajogi és közalkalmazotti szabályrendszer összehangolása, s ily módon a 2007-ben megjelent alapkönyv aktualizálása. A két kötetes kiadvány a közszférában alkalmazott új és a továbbra is hatályban maradt munkajogi szabályokat együttesen mutatja be. A könyv az új Mt. hatálybalépésével összefüggő átmeneti rendelkezéseket is ismerteti, valamint az első kötetben a közalkalmazottak jogállásáról szóló 1992. évi XXXIII. törvény (Kjt.), a második kötetben pedig a közszolgálati tisztviselőkröl szóló 2011. évi CXCIX. törvény (Kttv.) rendelkezéseit. Mindezt példákkal és a vonatkozó végrehajtási rendeletek szabályaival egészítik ki. (B. K.)

- Egészségkárosodáshoz kapcsolódó ellátások - Rokkantság, rehabilitáció közérthetően

Dósa Ágnes-Hantı Péter

(Sorozat: Egészségügyi kiskönyvtár, ISSN 2063-2282; 2.)

CompLex, Budapest, 2012

Szakkönyv. Terjedelem: 489. Bibliográfia nincs. ISBN 9789632249957

- A szerzők oktatók, valamint gyakorló orvos-jogászok. Az egészségbiztosítás terén 2012-ben életbe lépő változások ismertetésére törekednek, amivel az a céljuk, hogy egyfajta útmutatót adjanak azon szakemberek számára, akik eljárnak az egészségkárosodáshoz, fogyatékossághoz kapcsolódó ellátások megállapítása során. Emellett azonban azoknak is szól a könyv, akik ilyen jellegű ellátásért folyamodnak. A szerzők a vonatkozó uniós és nemzetközi szabályok, hazai jogszabályok, a bírói gyakorlat, valamint gyakorlati példák révén igyekeznek átfogó képet adni arról, hogy ki és milyen ellátás igénybe vételére jogosult rokkantság, illetve fogyatékosság esetén. (B. K.)

- Társadalombiztositás

Futó Gábor

Penta Unió, Pécs, 2012

Szakkönyv. Terjedelem: 197. Bibliográfia nincs. ISBN 9789638921093

- A szerző ügyvéd és társadalombiztosítási szakértő. A könyv felépítése a társadalombiztosítási ellátásokról szóló szabályokat tartalmazó 1997. évi LXXX. törvény (Tbj.) szerkezetét követi, és tartalmazza a 2011-2012-ben bekövetkezett változásokat. A Tbj. olyan alapvető kérdéseit és rendelkezéseit mutatja be, mint a biztosítási és járulékfizetési kötelezettség, valamint az egyes ellátásokra való jogosultság feltételei. Emellett a szerző röviden foglalkozik a társadalombiztosítás nemzetközi vonatkozásaival is, ezen belül is elsősorban azzal, hogy miként vehetők igénybe a különböző ellátások az Európai Gazdasági Térség tagállamaiban. 
A függelékben megtalálható a Tbj. valamint végrehajtási rendeletének a 2012 . január 1-jén hatályos szövege. (B. K.)

- Társadalombiztosítás, 2012: biztosítási kötelezettség, járulékfizetés, nyilvántartás, jogosultság társadalombiztositási ellátásra, nemzetközi társadalombiztositási szabályok

Futó Gábor

Kompkonzult, Budapest, 2012

Szakkönyv. Terjedelem: 327. Bibliográfia nincs. ISBN 9789639427846

- A szerző ügyvéd és társadalombiztosítási szakértő. A könyv felépítése a társadalombiztosítási ellátásokról szóló szabályokat tartalmazó 1997. évi LXXX. törvény (Tbj.) szerkezetét követi, és tartalmazza a 2011-2012-ben bekövetkezett változásokat. A társadalombiztosítás olyan alapvető kérdéseit és rendelkezéseit mutatja be, mint a biztosítási és járulékfizetési kötelezettség, valamint az egyes ellátásokra való jogosultság feltételei. Emellett a kötet harmadik része teljes egészében a társadalombiztosítás nemzetközi szabályairól szól, így tárgyalja például a társadalombiztosítási ellátások igénybevételének feltételeit harmadik államban, valamint az Európai Gazdasági Térség államaiban. Ezen kívül a szociális koordináció szabályai és alapelvei is bemutatásra kerülnek. (B. K.)

- Jogszabálygyüjtemény a szociális jog különös rész tanulmányozásához Homıcskó Árpád Olivér

(Sorozat: Werbőczy-sorozat, ISSN 2062-2538)

Patrocinium, Budapest, 2012

Jogszabálygyüjtemény. Terjedelem: 169. Bibliográfia nincs.

ISBN 9786155107849

- A szerző egyetemi oktató. A kiadvány a szociális joghoz szükséges jogszabályok kivonatát tartalmazza egy helyen, ezzel is megkönnyítve a hallgatók számára a tárgy tanulását. Ahol szükségesnek tűnt, a szerző rövid kommentárral látta el a jogszabályi rendelkezéseket a könnyebb érthetőség érdekében. A könyv a szociális jogon belül öt nagy témakörrel foglalkozik: az egészségbiztosítással, a nyugellátással, a foglalkoztatáspolitikával, a szociális igazgatás körében nyújtott ellátásokkal, valamint a családtámogatással. Valamennyi témakör tekintetében röviden kifejti, hogy az a szociális jog rendszerén belül hol helyezkedik el. A kézirat 2012. október 28-án került lezárásra, így a könyv az e napon hatályos jogszabályokat tartalmazza. (B. K.)

- Munka- és környezetvédelem

HORVÁtH József

Tankönyvmester, Budapest, 2012

Egyetemi tankönyv. Terjedelem: 236. Bibliográfia nincs. ISBN 9789632750569

- A könyv az azonos címen már többször is megjelent tananyag átdolgozott, sorszám nélküli kiadása. A munkavédelem keretein belül felvillantja az alapvető fogalmakat, a munkaviszony alanyait terhelö jogokat és kötelezettségeket. Mindezeken túlmenően kitér a munkabiztonság és a munkaegészségügy rendszerére 
egy-egy önálló fejezetben. Olyan gyakorlati ismereteket is átad, amelyek lehetővé teszik a körültekintő munkavégzést, illetve segítenek a bekövetkezett esetleges baleset körüli teendők ellátásban. A tűzvédelem körében komplex módon ismerteti a tűzveszélyes tevékenységeket, a tűzoltás szabályait és a tűzvédelmi hatósági feladatokat. A környezetvédelem jelentőségét hangsúlyozva részletezi a környezeti ártalmakat és a környezetvédelem egyes részterületeit. (D. D.)

- Munka- és környezetvédelem: a modulrendszerü szakképzéshez HoRvÁtH József

Tankönyvmester, Budapest, 2012

Egyetemi tankönyv. Terjedelem: 220. Bibliográfia nincs. ISBN 9789632751238

- A könyv az azonos már többször is megjelent tananyag átdolgozott, sorszám nélküli kiadása, amely a kompetencia alapú, modul rendszerü követelményrendszer figyelembe vételével készült. A munkavédelem rendszerének elméleti és gyakorlati oldalát egyszerre szemlélteti az általános szabályok, a munkahelyen betartandó magatartási követelmények, illetve az egészséges és biztonságos munkavégzés követelményeinek ismertetésével. Általános tűzvédelmi ismereteken túlmenően a tủzvédelem szabályait, továbbá a preventív intézkedéseket hangsúlyozza. A környezetvédelem rendszerébe rövid bepillantást nyújt; annak egyes területeit, módszereit, a környezeti ártalmakat és a természeti értékek megóvása körében szükséges szabályokat tárgyalja. (D. D.)

- A társadalombiztositási jogszabályok egységes szerkezetben, magyarázatokkal, 2012

JuRÁnYI Benedekné-Matlné KisARI Erika-PINTÉRné MolnÁR llona-SzélL Zoltánné (Sorozat: Jogalkalmazások, ISSN 2060-8373)

Saldo, Budapest, 2012

Kézikönyv. Terjedelem: 266. Bibliográfia nincs. ISBN nincs. ISSN 2061-0076

- A szerzők a Nemzeti Adó- és Vámhivatal munkatársai. Könyvükkel (amelyet évente aktualizálnak, s az ehhez igazodó címmel újra kiadnak) elsősorban a társadalombiztosítás szabályait alkalmazó szakembereknek kívánnak segítséget nyújtani abban, hogy a társadalombiztosítás fedezeti rendszerének, valamint a nyugdíjrendszernek a 2012. évi átalakítását követöen is naprakész tudással rendelkezzenek. A kötet a 2012. január 1-jétöl hatályos szabályokat átfogó módon tartalmazza, felépítése alapvetően a társadalombiztosítási ellátásokról szóló 1997. évi LXXX. törvény szerkezetét követi. A törvényi rendelkezésekhez füzött magyarázatok, gyakorlati példák, táblázatok, valamint a bírói gyakorlat ismertetése révén a mindennapi életben felmerülö konkrét problémák megoldásában is hasznosítható a kötet. (B. K.)

- A szakképzési törvény kézikönyve

KLÉsz Tibor

CompLex, Budapest, 2012

Kézikönyv. Terjedelem: 536. Bibliográfia: 533-536. és a lábjegyzetekben. ISBN 9789632950006 
- A szerző a képzés területén járatos szakember. Könyvével a szakképzés rendszerét jelentős mértékben átalakító 2011. évi CLXXXVII. törvényhez kíván útmutatót adni. Bemutatja a törvény megalkotásának hátterét, $s$ részletekbe menően magyarázza meg egyes rendelkezéseit. Mivel a szerző kimondott célja az iskolarendszerü szakképzés területének átfogó bemutatása és tágabb kontextusba helyezése, ezért ismertetésre kerülnek a szakképzéshez kapcsolódó munkajogi, foglalkoztatási, önkormányzati, költségvetési, társasági, adójogi és polgári jogi szabályok is. A kézikönyv elsősorban a gyakorlat számára készült: a szakképzésben érintett és érdekelt szereplöknek, köztük a jogalkalmazóként tevékenykedőknek igyekszik segítséget nyújtani. (B. K.)

- Nyugdíj és gyermekvállalás

Kovács Erzsébet (szerk.)

(Sorozat: Társadalombiztosítási könyvtár, ISSN 2063-2479)

Gondolat, Budapest, 2012

Tanulmánykötet. Terjedelem: 180. Bibliográfia tanulmányonként és a lábjegyzetekben. ISBN 9789636934583

- A szerkesztő és a tanulmányok szerzői közgazdászok, oktatók. A kötet a 2012ben Budapesten a Budapesti Corvinus Egyetem és az Országos Nyugdíjbiztosítási Főigazgatóság által azonos címmel megrendezett konferencia előadásainak, valamint a hozzájuk kapcsolódó referátumoknak a szerkesztett anyaga. Az elöadások középpontjában az a kérdés állt, hogy szükséges-e, és ha igen, akkor hogyan lehetséges a gyermekvállalás elismerése a nyugdíjrendszeren keresztül. Az előadók nem csak a szükebb szakmai körnek, hanem a szélesebb érdeklődő közönségnek is szánják mondandójukat, a tanulmányok megértése ezért nem igényel szakmai képzettséget. (B. K.)

\section{- Családtámogatási kézikönyv}

Orbán Zsófia-PAPP Andrea Krisztina

CompLex, Budapest, 2012

Kézikönyv. Terjedelem: 242. Bibliográfia nincs. ISBN 9789632950792

- A szerzők gyakorló jogászok. Mivel a családtámogatás témája iránt érdeklődők köre a szakmai hozzáértést és a szakmai jártasságot tekintve igen heterogén, könyvüket a következöképp építették fel: egyfelöl az egyes jogszabályi rendelkezésekhez füzött magyarázatot a jogban jártas szakemberek hagyományos kommentárként használhatják; másfelöl a kötet gyakorlatias megfogalmazású, szakmai magyarázó anyagot is tartalmaz, melyet a hétköznapi életből vett példákkal és a bírósági gyakorlattal egészítettek ki a szerzők, segítséget nyújtva a jogalkalmazáshoz. A könyv átfogóan tárgyalja a családok támogatásáról szóló törvényt, a kapcsolódó végrehajtási rendeletet, valamint a vonatkozó uniós szabályokat. (B. K.)

\section{- Magyar munka- és közszolgálati jogi reform európai kitekintéssel}

PRugberger Tamás

Második, bővített kiadás. Novotni, Miskolc, 2012

Monográfia. Terjedelem: 311. Bibliográfia a fejezetek végén. 
- A szerző egyetemi oktató. A könyvben végig veszi mind az individuális, mind a kollektív munkajog intézményeit, amely során a 2012. évi új munka törvénykönyvben található intézményeket és új szabályokat összehasonlítja az uniós joggal, valamint az EU tagállamainak jogával, s ennek során kritikai észrevételeit is megfogalmazza a megváltozott rendelkezések vonatkozásában. Az egyes fejezetek végén a jegyzeteken túl Kenderes György és Nádas György által írt glosszák találhatók. A függelékben a szerző kikéri a legjelentősebb munkavállalói érdekvédelmi szervezetek elnökeinek, valamint Szili Katalinnak az új Munka Törvénykönyvével kapcsolatos véleményét. (B. K.)

- A nyugdíjbiztositási ellátások fenntarthatóságának jogi garanciái RAB Henriett

HVG-ORAC, Budapest, 2012

Monográfia. Terjedelem: 342. Bibliográfia: 307-342. és a lábjegyzetekben. ISBN 9789632581767

- A szerző egyetemi oktató. A monográfia a szerző azonos című PhD-értekezésének átdolgozott változata, amelyben a magyar jogtudományban korábban elhanyagolt jogi alapkérdéseket, a nyugdíjbiztosítási ellátások fenntarthatóságának jogi garanciáit mutatja be. A szerző elsődlegesen a szociális jogokra való jogosultság alapjogi hátterét vizsgálja, kitérve mind a nemzetközi, mind a hazai jogi környezetre. Elsősorban a nyugdíjbiztosítás hatályos szabályai, valamint ehhez kapcsolódóan a releváns alkotmánybírósági határozatok kerülnek bemutatásra, a jogvédelem irányának szempontjából rendszerezve. Mindezt a szerző kiegészíti gazdasági kérdések és lehetőségek vizsgálatával, s ily módon komplex képet ad a társadalombiztosítás és a nyugdíjbiztosítás rendkívül összetett viszonyrendszeréröl. (B. K.)

- Az új munka törvénykönyve: gyakorlati alkalmazása és összevetése a korábbi elöírásokkal

RÁTKAl Ildikó

Menedzser Praxis, Budapest, 2012

Szakkönyv kapcsos borítóban, cserélhető lapokkal. Bibliográfia nincs.

ISBN nincs. ISSN 2063-2223

- A szerző ügyvéd, munkajogász, könyve pedig - újabb, sorszám nélküli átdolgozott kiadásban - a 2012. július 1-jén hatályba lépett új munka törvénykönyve átfogó ismertetését adja. Az ismertetésen túl összehasonlítást is tartalmaz, a régi és az új jogszabály vonatkozásában. Egymástól jól elkülönítve átláthatóvá válnak azok a szabályok, amelyek módosultak a régi szabályokhoz képest. A bemutatásból kitünik, hogy az új Mt. - szakítva a korábbi tradíciókkal - magán viseli a polgári jog jegyeit. A szerző rávilágít arra is, hogy az új törvény mennyire van figyelemmel a nemzetközi jogi, uniós jogi rendelkezésekre, illetve az Alaptörvényre. (D. D.)

- A Munka törvénykönyve 2013. január 1-töl

SCHNIDER Marianna

(Sorozat: Szakszervezeti kiskönyvtár, ISSN 1787-1824; 32.) 
- A szerző szakszervezeti munkajogász. A könyv az új munka törvénykönyve (2012) rendelkezéseit veszi sorra olyan módon, hogy az egyes részek nem a törvény szövegét ismétlik meg, hanem annak közérthetöbb leírását adják. Jól kirajzolódnak a jogszabály azon pontjai, amelyek a munkáltató mozgásterét jelentősen kibővítik, egyúttal a munkavállalói szociális biztonság csökkenésére vezetnek. A szerző kiemelt figyelmet fordít azokra az intézményekre, amelyek az új törvénytervezet egyeztetései során szakszervezeti nyomás hatására módosultak, nevezetesen a személyhez füződő jogok, a kártérítés, a munkaidő és a kötelezettségszegés intézményére. (D. D.)

- A közúti fuvarozás és szállitás szociális jogszabályainak kérdései az utakon Szabados Tibor-Kuzma Ferenc Kuzma \& Kuzma AETR Tanácsadó Bt., Budapest, 2012 Szakkönyv. Terjedelem: 175. Bibliográfia nincs. ISBN 9789630847322

- A szerzők oktatók, valamint a fuvarozás területén dolgozó szakemberek. Elsődlegesen az a céljuk, hogy a fuvarozással foglalkozó vállalkozásokat, valamint a náluk dolgozó gépjárművezetőket érdeklő, jelentősebb kérdéseket a gyakorlat oldaláról vizsgálva megválaszolják. A könyvben 131 kérdés és az azokra - szakértö, illetve igazságügyi szakértő által - adott válasz található. Mindezek három nagy témakörhöz tartoznak: a fuvarozókat érintő kérdéseket a saját számlás szállítással foglalkozóknál felmerülö problémák, végül munkaügyi kérdések követik. (B. K.)

- Társadalombiztositási ügyintézök kézikönyve, 2012

SzAFKó Zoltánné-SzÉLES Imre-TótH Liboriuszné

Perfekt, Budapest, 2012

Kézikönyv/Tankönyv. Terjedelem: 304. Bibliográfia nincs. ISBN 9789633948163

- A szerzők oktatók, illetve a társadalombiztosítás területén tevékenykedő gyakorlati szakemberek. Könyvüket azoknak szánják, akik a társadalombiztosítás területén 2012-ben bekövetkezett számtalan változás között szeretnének eligazodni. A könyv a társadalombiztosítási ügyintéző szakképzés teljes anyagát feldolgozva segít a képzésben részt vevők számára a vizsgára való felkészülésben, ám átfogó jellegének köszönhetően a már végzett szakemberek is hasznát veszik a mindennapi munkavégzés során. A könyv bemutatja a társadalombiztosítás alapelveivel, a nyugellátással, az egészségbiztosítási, szociális és családtámogatási ellátásokkal kapcsolatos alapfogalmakat és részletszabályokat. A társadalombiztosítás szabályainak jobb megértését gyakorlati példák segítik. $E$ mellett röviden a munkajog alapvetö szabályait is bemutatja a könyv. (B. K.)

- Privacy in the workplace: data protection law and self-regulation in Germany and Hungary

Szőke Gergely László (szerk.)

(Sorozat: Infocommunication and law books, ISSN 2060-5021)

HVG-ORAC, Budapest, 2012

Szakkönyv. Terjedelem: 342. Bibliográfia: 141-161., 339-342. és a lábjegyzetekben. ISBN 9789632581972 
- A szerkesztő gyakorló jogász és oktató; a kötet elkészítésében az adatvédelem és a munkajog területén jártas hazai és külföldi egyetemi oktatók, illetve kutatók müködtek közre. A könyv az informatika fejlődése révén a munka világában megjelenő új kihívásokat kívánja elemezni. Mivel a munkahelyeken egyre elterjedtebb az informatikai eszközök használata, a munkáltatók az üzleti titok és a know-how védelme érdekében új eszközökhöz nyúlnak a munkavállalók megfigyelése és ellenőrzése, illetve személyes adataik kezelése terén, ami a munkavállalók magánszférához való jogának sérelmét eredményezheti. Tulajdonképpen az ezen új helyzetet elemző, az Európai Unió által is finanszírozott PAW projektet és annak konklúzióit összegzi a kötet, amivel a munka világának valamennyi szereplője, valamint a jogalkalmazók számára kíván segítséget nyújtani. (B. K.)

\section{PÉNZÜGYI JOG}

- Közbeszerzési definíciógyüjtemény

Barna Orsolya (szerk.)

CompLex, Budapest, 2012

Kézikönyv. Terjedelem: 191. Bibliográfia: 191. ISBN 9789632950099

- A szerzők gyakorlati szakemberek. A közbeszerzésekről szóló 2011. évi CVIII. törvény új alapokra helyzete a közbeszerzési szabályozást, melyhez számos végrehajtási rendelet is kapcsolódik. A könyv a törvény fogalmainak értelmezéséhez és a joganyagok mindennapi alkalmazásához nyújt segítséget. Mind az ajánlatkérők, mind az ajánlattevők számára tartalmaz hasznos információkat, gyakorlati tapasztalatokat. Számos táblázat segít átlátni a közbeszerzési eljárási határidőket az uniós és a nemzeti eljárásokban, valamint a kizáró okokat az új rendszerben. Kiemelten tárgyalásra kerülnek a zöld és a fenntartható közbeszerzések. (B. P.)

- A beruházásösztönzés adójoga

ERDös Éva

Miskolci Egyetem, Miskolc, 2012

Monográfia. Terjedelem: 239. Bibliográfia: 229-239. és a lábjegyzetekben. ISBN 9789633580196

- A szerző egyetemi oktató. A könyv a beruházás-ösztönzéssel mint az adójog egyik speciális eszközével foglalkozik. Egyedülálló abban a tekintetben, hogy a nemzetközi tökeáramlás adójogi környezetét mint lehetséges motivációs vagy megtartó erőt vizsgálja. A könyv az 1990-es évektöl napjainkig dolgozza fel a beruházás-ösztönzés hazai és európai uniós adójogi szabályozását. Középpontjában a külföldi beruházásokat érintő társasági adókedvezmények és az állami támogatások, mint adókedvezmény állnak, az adóharmonizáció előrehaladását figyelembe véve. Olyan napi gazdaságpolitikai kérdéseket is érint a szerző, mint az adóverseny, az adóelkerülés vagy az adószuverenitás. A kötet a tételes szabályozás mellett a gyakorlati tapasztalatokat is feldolgozza. (B. P.) 
- Adótan

HERICH György

(Sorozat: Adó abc, ISSN 1416-8111)

Penta Unió, Pécs, 2012

Tankönyv. Terjedelem: 399. Bibliográfia a lábjegyzetekben. ISBN 9789638921079

- A szerző egyetemi oktató, okleveles adószakértő. A könyv a közbevételek jogával foglalkozik, bemutatja a legfrissebb tételes anyagi- és eljárásjogi adószabályokat az adórendszer elemeinek, összefüggéseinek és kapcsolatainak tükrében. Részletesen ismerteti a központi költségvetés szerkezetét, a magánszemélyek és vállalkozások adózására vonatkozó szabályokat (a 2012-es évre vonatkozóan), a társadalombiztosítási rendszert, valamint a közösségi vámszabályokat. A szerző a hagyományos magyarázatok mellett logikai ábrák segítségével szemlélteti az adórendszer világát. (B. P.)

- Közpénzügyi menedzsment

Hőgye Mihály (szerk.)

Aula, Budapest, 2012

Tankönyv. Terjedelem: 226. Bibliográfia az egyes fejezetek végén. ISBN 9789633390276

- A szerzők egyetemi oktatók. A kötet fókuszában a közpénzügyek egyik fontos kérdése, a központi költségvetés végrehajtásának menedzselése áll, számviteli, ellenőrzési megközelítésben. A költségvetési ciklus és az ahhoz kapcsolódó intézményrendszer egyes elemei adják a könyv gerincét. A kötet az állami funkciókat és a szerepvállalást, a költségvetési tervezést és ellenőrzést, valamint a közbeszerzés és kiszerződés értelmezését mutatja be hét fejezeten át. A témakörök között szerepel még az adósságkezelés és az állami vagyongazdálkodás menedzsment szempontú szabályozási kérdései, amelyek kapcsán a könyv mind a hazai, mind pedig az Európai Unió hatályos szabályozását tartalmazza. Számos táblázat és példa kívánja érthetőbbé és tanulhatóbbá tenni a tankönyv anyagát. (B. $P$.)

- A társasági adóról és az osztalékadóról szóló törvény egységes szerkezetben, magyarázatokkal

H. Nagy Dániel (szerk.)

(Sorozat: Jogalkalmazások, ISSN 2060-8373)

Saldo, Budapest, 2012

Kommentár. Terjedelem: 335. Bibliográfia nincs. ISBN 9789636934224

- A kötet szerzői gyakorló szakemberek, a Nemzeti Adó- és Vámhivatal munkatársai. A kötet a többször módosított, a társasági adóról és az osztalékadóról szóló 1996. évi LXXXI. törvény 2012. május 1-jén hatályos, magyarázatokkal ellátott szövegét tartalmazza. (B. P.)

- A közbeszerzés joga. Kommentár a gyakorlat számára

Patay Géza (szerk.)

Hatodik, átdolgozott kiadás. HVG-ORAC, Budapest, 2012

Kézikönyv. Terjedelem: 828. Bibliográfia nincs. ISBN 9789639203149 
- A szerzők közbeszerzésekkel foglalkozó elméleti és gyakorlati szakemberek. A közbeszerzések szabályozása új alapokra került a 2011. évi CVIII. törvény hatályba lépésével. A kötet az új közbeszerzési törvény jogintézményeit, valamint a hozzá kapcsolódó végrehajtási jogszabályokat dolgozza fel átfogó jelleggel. A szükséges helyeken ismerteti a közösségi szabályokat, illetve az Európai Bíróság gyakorlatát, továbbá beépíti a korábbi döntöbizottsági és bírósági határozatokat, melyek továbbra is zsinórmértéket jelenthetnek a jogalkalmazók számára. A kötet felhívja a figyelmet a jogalkalmazás lehetséges buktatóira és ezek elkerülésére megoldási javaslatokat is kínál. (B. P.)

\section{- Az államháztartás pénzügyi ellenörzési rendszere - Kiemelt kérdések}

SEBEs József

Nemzeti Tankönyvkiadó, Budapest, 2012

Monográfia. Terjedelem: 195. Bibliográfia: 169-176. ISBN 9789631973150

- A szerző a közgazdaságtan és a politikatudományok doktora, munkája 2008-ban megvédett doktori disszertációján alapul. A kötet a pénzügyi ellenőrzés témakörét komplexen tárgyalja. A fogalmak meghatározása, e tevékenység tartalmának és rendszerének bemutatása mellett a hazai pénzügyi ellenőrzési rendszer rövid történeti áttekintését is adja. Az elméleti alapvetést követöen az államháztartás belső pénzügyi ellenőrzési rendszerére, annak elemeire, helyzetére, továbbfejlesztésének alternatíváira és a kapcsolódó vitás kérdésekre fókuszál. A szerző elemzéseiből kiderül, hogy hazánkban az államháztartás belső pénzügyi ellenőrzési rendszerében az új típusú szabályozás bevezetése elött is jelen voltak olyan elemek, amelyek megfeleltek az Európai Unió követelményeinek, ugyanakkor a fennáló struktúra jelenlegi formájában még nem felel meg a vele szemben támasztott valamennyi uniós elvárásnak. ( $V$. J.)

\section{- Az adózás nagy kézikönyve}

SzAKÁcs Imre

(Sorozat: Meritum, ISSN 1788-6198)

CompLex, Budapest, 2012

Kézikönyv. Terjedelem: 1880. Bibliográfia nincs. ISBN 9789632249995

- A szerző 2007-töl minden évben megjelenteti e kötetet. A 2012-es kiadás is a magyar adójog részletes bemutatására vállalkozik, a szerkezeti felépítés rendező elve a fizetési kötelezettségek jellege. A szerző külön részben tárgyalja a fogyasztáshoz, forgalomhoz kapcsolódó központi adókat, járulékokat, hozzájárulásokat és egyéb elvonásokat. Ezt követően a vállalkozásokból származó nyereséget és a személyi jövedelmeket terhelő központi fizetési kötelezettségeket veszi számba, majd az önkormányzatokat megillető adók kerülnek sorra. Külön részt kaptak az egyéb, fenti kategóriába nem sorolható fizetési kötelezettségek, mint a bányajáradékok, innovációs járulék, az ágazati különadó vagy a baleseti adó. A fizetési kötelezettségek szabályanyagának részletes bemutatását az adózás rendjére vonatkozó előírások zárják. (V. J.) 
- Adótani alapok

Sztanó Imréné (szerk.)

Saldo, Budapest, 2012

Tankönyv. Terjedelem: 297. Bibliográfia az egyes fejezetek végén. ISBN 9789636384173

- A szerzők között találunk egyetemi tanárt, egyetemi oktatót, gyakorlati szakembert. A könyv célja átfogó ismeretek közvetítése az adórendszer vonatkozásában. Ennek megfelelően az egyes fejezetek a rendszert érintő kérdések összegzésére törekszenek, úgymint az adózás gazdaságban betöltött szerepének, az adózás történetének, az adórendszerek kialakulásának, az adójogi környezetnek, a különböző adótípusoknak, illetve a nemzetközi adózásnak és az Európai Unió adózással összefüggő rendelkezéseinek a bemutatására. A tananyag elsajátítását a szerzők ábrákkal, táblázatokkal, továbbá az egyes fejezetek végén az alapfogalmak összegyűjtésével, önellenőrző, valamint vitakérdések feltételével segítik. (V. J.)

\section{POLGÁRI JOG, POLGÁRI ELJÁRÁSI JOG}

- Atipikus szerződések: döntvénytár és példatár AUER Ádám Lectum, Szeged, 2012

Döntvénytár. Terjedelem: 210. Bibliográfia nincs. ISBN 9789639640429

- A szerző egyetemi oktató. A kötet két egységre bontható: az első rész, a döntvénytár az atipikus szerződésekkel kapcsolatos bírósági gyakorlatot dolgozza fel, a második, a példatár pedig az atipikus szerződések témakörében jogeseteket és hibás szerződéseket tartalmaz. A döntvénytár tematikus elrendezést és számozott rendszert követ: összefoglalja a szindikátusi szerződés, a PPP-szerződés, a távollevők között kötött szerződés, az önálló kereskedelmi ügynöki szerződés, a timesharing szerződés, a konzorciós szerződés, a koncessziós szerződés, a licenciaszerződés, a franchise szerződés, a merchandising szerződés, a lízingszerződés, a faktoring szerződés és a kezelési szerződés vonatkozó bírósági esetjogát. (T. E.)

- Kötelmi jog: általános rész

Besenyel Lajos

(Sorozat: A Pólay Elemér Alapítvány tansegédletei, ISSN 1786-3554)

Harmadik, átdolgozott kiadás. Pólay Elemér Alapítvány, Szeged, 2012

Tansegédlet. Terjedelem: 300. Bibliográfia a lábjegyzetekben.

ISBN 9789639650916

- A szerző a Szegedi Tudományegyetem oktatója. A tansegédlet a magyar kötelmi jog általános részének szabályait tartalmazza. Elsőként a kötelmi jog általános, valamennyi kötelem-keletkeztető tényállásra vonatkozó szabályanyagát tárgyalja. Ezt a fejezetet a szerződések közös szabályainak ismertetése követi, majd az értékpapírra vonatkozó Ptk.-beli szabályok kerülnek bemutatásra. A tankönyv 
a Ptk. felelősségi szabályait több fejezetre bontva tárgyalja, végezetül pedig a jogalap nélküli gazdagodásra, illetve az utaló magatartásért való helytállásra vonatkozó rendelkezéseket mutatja be. (K. J. M.)

- Kötelmi jog: különös rész

BESENYEI Lajos

(Sorozat: A Pólay Elemér Alapítvány tansegédletei, ISSN 1786-3554)

Pólay Elemér Alapítvány, Szeged, 2012

Tansegédlet. Terjedelem: 262. Bibliográfia a lábjegyzetekben.

ISBN 9789639650947

- A szerző a Szegedi Tudományegyetem oktatója. A tankönyv az egyes szerződések különös szabályait tartalmazza. Először a dologszolgáltató szerződések alaptípusa, az adásvétel, és annak különös nemei, majd a csereszerződés, a szállítási szerződés, illetve a közüzemi szerződés kerülnek tárgyalásra. Ezt a vállalkozási típusú szerződések bemutatása követi, majd a bérlet a non facere szerződések alaptípusaként, annak legjellemzőbb altípusaival együtt kerül bemutatásra. A megbízási típusú szerződéseket követően a praestare jellegű szerződéseket ismerteti, melyekhez kapcsolódóan egyes fizetési módozatok bemutatásra is sor kerül. A társaságokra vonatkozó Ptk.-beli szabályok szintén önálló fejezetet alkotnak, végezetül pedig a tartási és életjáradéki szerződést, illetve egyéb kötelem-keletkeztető tényállásokat (díjkitűzés, kötelezettségvállalás közérdekű célra) tárgyalja a kötet. (K. J. M.)

- Változó civil világ. Kézikönyv civil szervezetek számára Bódı György et al.

CompLex, Budapest, 2012

Kézikönyv. Terjedelem: 395. Bibliográfia: 393-395. ISBN 9789632952192

- A szerzők különféle társadalomtudományi területek szakértői, így találunk köztük jogászt, közgazdászt, politológust és civil ügyekben járatos bírót is. Kötetük célja a civil szervezetekre irányadó jogszabályi környezet változásainak áttekintése, a legaktuálisabb ismeretek közreadása. A gyakorlatorientált feldolgozás a civil szervezetek létrejöttével, müködésével, gazdálkodásával, támogatásával kapcsolatos kérdésekre, illetve adózási és számviteli elöírásokra irányul. A kötetben nagy hangsúlyt kap többek között a közhasznúság új értelmezése és a bírósági eljárás új követelményeinek ismertetése. (B. L.)

\section{- Előadásvázlatok a polgári jog általános tanaiból}

Boóc Ádám-SÁNDOR István

(Sorozat: Bethlen-sorozat, ISSN 2062-2546)

Harmadik, átdolgozott és bővített kiadás. KRE ÁJK Polgári Jogi és Római Jogi Tanszék-Patrocinium, Budapest, 2012

Egyetemi jegyzet. Terjedelem: 181. Bibliográfia: 175-181. és az egyes fejezetek végén. ISBN 9786155107832 
- A szerzők egyetemi oktatók. A tansegédlet a Polgári jog I. tantárgy keretében elhangzott előadások anyagának összefoglalóit közli az oktatásban egyébként alkalmazott jegyzetekre és tankönyvekre támaszkodva. Az előadásvázlatok nem teljes körüek, így csak a polgári jog általános tanai körébe tartozó leghangsúlyosabb témakörök kerülnek bemutatásra, közérthető példákkal szemléltetve. A szerzők emellett igyekeztek röviden bemutatni az új Ptk. várható újdonságait is. (K. G. M.)

\section{- A társasági jog és a cégjog alapjai}

FARKAS Csaba

Szerzői kiadás, Szeged, 2012

Egyetemi jegyzet. Terjedelem: 144. Bibliográfia nincs. ISBN 9789630848435

- A szerző egyetemi oktató. A kiadvány meglehetősen röviden, ám lényegre törően foglalja össze az alapvető társasági jogi és cégjogi normákat és ismereteket. A történeti elözmények tömör ismertetését követően bemutatja a valamennyi gazdasági társaságra vonatkozó általános és az egyes gazdasági társaságokra vonatkozó különös szabályokat, illetve a gazdasági élet további fontos szereplőiként az egyéni vállalkozóval és az európai részvénytársasággal is foglalkozik. (B. L.)

\section{- Társasági jogviták}

FÉzer Tamás

(Sorozat: Bírói Gyakorlat Füzetek, ISSN 2063-725X; 2.)

Opten, Budapest, 2012

Döntvénytár/Kézikönyv. Terjedelem: 227. Bibliográfia nincs.

ISBN 9786155122033

- A szerző egyetemi oktató. A kötetben a 2007-től 2012-ig terjedő időszak bírósági határozataiból válogat olyanokat, amelyek a társasági jog egyes intézményeit értelmezik. A kiadvány a társasági jog lényeges elemeit (pl. tagok felelőssége, tag kizárása, tagok társasággal szembeni kártérítési igénye) a legfontosabb döntéseken keresztül mutatja be úgy, hogy az egyes ítéletek ismertetéséhez a szerző saját értékelést is füz. A felölelt esetjog egy része szükségszerüen még a II. Gt.-n alapul, azonban a kiadványban csak olyan bírósági döntések szerepelnek, amelyek a III. Gt. azonos tartalmú szabályaihoz is kapcsolhatók. (B. L.)

- Európai jogi kultúra. Megújulás és hagyomány a magyar civilisztikában Fuglinszky Ádám-Klára Annamária (szerk.)

ELTE Eötvös Kiadó, Budapest, 2012

Tanulmánykötet. Terjedelem: 606. Bibliográfia a lábjegyzetekben. ISBN 9789633121047

- A kötet a Magánjogot Oktatók Egyesülete és az ELTE ÁJK szervezésében 2011. június 17-18-án az e címmel megrendezett konferencián elhangzott előadások szerkesztett változatát adja közre. A tanulmányok a szélesebb értelemben vett magánjog valamennyi területét lefedik, így a polgári jog mellett a polgári eljárásjog, a versenyjog, a munkajog, valamint az európai társasági jog legújabb tendenciáiról is tartalmaz közleményeket. A szerzők között valamennyi magyarországi jogi kar egy vagy több képviselője megtalálható. (K. J. M.) 
- A kereskedelmi kommunikáció szabályozása a médiajogban

GeLLÉn Klára

(Sorozat: Infokommunikáció és jog könyvek, ISSN 2060-5021)

HVG-ORAC, Budapest, 2012

Monográfia. Terjedelem: 131. Bibliográfia: 129-131. és a lábjegyzetekben.

ISBN 9789632581620

- A szerző egyetemi oktató és gyakorló ügyvéd. Kötetében a média és a kereskedelmi kommunikáció speciális kapcsolatát vizsgálja: a reklámjellegủ tartalmak tömegkommunikációs eszközökben való megjelenítését. Ez az igen speciális témakör tulajdonképpen a magát, illetve termékét reklámozó gazdasági szereplö, a média, valamint a kereskedelmi célú beszéd korlátozásának találkozási pontjában felmerülö kérdések tárgyalását jelenti. A kötet a reklámjog és a médiajog keresztmetszetét képező kereskedelmi közleményekre vonatkozó szabályozást, az ezekre vonatkozó korlátozásokat az Európai Unió joganyagára és a hazai gyakorlatra tekintettel elemzi. (K. G. M.)

- Javitandó és jobbitható elemek a Ptk. kodifikációjában

Gondosné Pusztahelyi Réka-Juhász Ágnes (szerk.)

Novotni, Miskolc, 2012

Tanulmánykötet. Terjedelem: 248. Bibliográfia a lábjegyzetekben.

ISBN 9789639360846

- A kötet a 2011-ben Miskolcon rendezett Polgári Jogot Oktatók Országos Találkozóján elhangzott elöadásoknak a 2012 februárjában nyilvánosságra került új Ptk.-javaslat fényében újragondolt, aktualizált írásos változatát adja közre. A tanulmányok egy része dogmatikai kérdésekkel, mások tételes jogi problémákkal foglalkoznak, és megjelenik néhány interdiszciplináris téma is, mint a polgári jog és a társasági jog, vagy a polgári jog és a munkajog kapcsolata egyes konkrét jogintézmények területén. (T. E.)

\section{- A know-how jogi védelmének alapvetö kérdései}

Görög Márta

(Sorozat: Infokommunikáció és jog könyvek, ISSN 2060-5021)

HVG-ORAC, Budapest, 2012

Monográfia. Terjedelem: 191. Bibliográfia: 183-191. ISBN 9789632581644

- A szerző egyetemi oktató. A kötet komplex jelleggel kívánja bemutatni az innováció és a gazdasági élet szempontjából kiemelkedő jelentőségü know-how jogintézményét. A téma fogalmi és elméleti megalapozása során áttekinti a jogelméletben megjelent know-how fogalmakat és a magánjogi védelem lehetőségeit. Ehhez a Ptk. rendelkezésein túl a vonatkozó versenyjogi és munkajogi rendelkezéseket, valamint a know-how transzfer szerződések (különösen a know-how licenciaszerződés és a know-how átruházási szerződés) elemeit is számba veszi. A szerző külön foglalkozik a know-how szerződés önálló szerződéstípusként való értelmezhetőségével, és ismerteti a know-how típusait és a titok magánjogi megitélését is. A kötet kitér az új Ptk. kodifikációja során kidolgozott koncepciókra és a 2012. évi Mt. módosított rendelkezéseire is. (T. E.) 
- A közjegyző és az értékpapírok

Havası Bálint Attila

Magánkiadás, Budapest, 2012

Kézikönyv. Terjedelem: 166. Bibliográfia: 163-166. és a lábjegyzetekben. ISBN 9789630846097

- A szerző gyakorló közjegyző. Kötetével a közjegyzőknek kíván gyakorlati segítséget nyújtani az értékpapírjog területén, így a könyv kereskedelmi forgalomban nem is jelent meg. A munka bemutatja az értékpapírok általános jellemzőit, az értékpapírjog vonatkozó jogszabályait, és külön is ismerteti az egyes értékpapírok sajátosságait - elsődlegesen azokat, amelyek a közjegyzői tevékenységgel öszszefüggnek (váltó, csekk, kötvény, részvény, letéti jegy). Önálló fejezet foglalkozik a közjegyzői tevékenység és az értékpapírok kapcsolatával, kitérve az állampapírokra is. (F. Á.)

- Polgári perrendtartás: 1952. évi III. törvény a polgári perrendtartásról. Kiegészítve a vonatkozó kollégiumi állásfoglalásokkal és jogegységi határozatokkal: egységes szerkezetben a 2013. január 1. napján hatálybalépő módosításokkal Hegedüs Bulcsú (szerk.)

(Sorozat: Werbőczy-sorozat, ISSN 2062-2538)

Patrocinium, Budapest, 2012

Jogszabálygyűjtemény. Terjedelem: 147. Bibliográfia nincs.

ISBN 9786155107740 (F. Á.)

- Szerzői jog

Hepp Nóra-FeJesné LöRINCz Anna

Szellemi Tulajdon Nemzeti Hivatala, Budapest, 2012

Tankönyv. Terjedelem: 98. Bibliográfia nincs. ISBN 9789639157705

- A kötet a Szellemi Tulajdon Nemzeti Hivatalának munkatársai által összeállított tankönyv, mely közérthetően, példákkal gazdagítva ad választ a napjainkban felmerülő legfontosabb szerzői jogi kérdésekre. Ismerteti a szerzői jogi védelem feltételeit, a szerzői művek felhasználásának módjait, a szabad felhasználás eseteit és a felhasználás korlátait, a jogérvényesítés eszközeit és az internetes környezetben előforduló, szerzői jogi szempontból releváns problémákat. Az egyes fejezetekhez megoldó kulccsal ellátott feladatok és ellenőrző kérdések kapcsolódnak. A munka a hivatal honlapján elektronikusan is elérhető. (T. E.)

- Kommentár a lakástörvényhez

HoRvÁth Gyula

CompLex, Budapest, 2012

Kommentár. Terjedelem: 272. Bibliográfia nincs. ISBN 9789632952260

- A szerző gyakorló ügyvéd. A kötet a lakások és helyiségek bérletére, valamint az elidegenítésükre vonatkozó egyes szabályokról szóló 1993. évi LXXVIII. törvény egyes rendelkezéseihez nyújt részletes magyarázatot, feldolgozva a legújabb bírói gyakorlatot is. A kommentár kitér a kapcsolódó jogszabályok (többek között a Ptk. és az ingatlan-nyilvántartásról szóló törvény) vonatkozó rendelkezéseire is. (B. $L$.) 
- Ha az adós nem fizet... A hitelezőt segitő jogi eszközök a pénzkövetelések érvényesítésére irányuló eljárásokban

KAPA Mátyás

Második, átdolgozott kiadás. HVG-ORAC, Budapest, 2012

Kézikönyv. Terjedelem: 263. Bibliográfia: 255-263. ISBN 9789632581545

- A szerző egyetemi oktató. A kötet a 2006-os első kiadáshoz hasonlóan bemutatja a hitelezők érdekeit védő jogi struktúrát, a polgári jogi, polgári eljárásjogi és büntetőjogi eszközöket, valamint a kapcsolódó európai uniós szabályozást, azonban az eltelt hat év globális gazdasági és jogszabályi változásaira, a követelések érvényesítésének nagyban átalakult jogi környezetére tekintettel átdolgozott tartalommal. A könyv elsődleges célja az, hogy a hitelező átlássa a követelés érvényesítésének teljes folyamatát, szembesüljön a követelés kielégítését hátráltató veszélyekkel, akadályokkal, így a követelések érvényesítése eredményesebb lehet. (M. J.)

- A szegényjogtól a jogi segítségnyújtásig

KIRÁlY Lilla

(Sorozat: Institutiones Juris, ISSN 1218-9375; Dialóg Campus szakkönyvek, ISSN 1417-7986)

Dialóg Campus-PTE ÁJK, Budapest-Pécs, 2012

Monográfia. Terjedelem: 238. Bibliográfia: 218-232. ISBN 9789639950856

- A szerző egyetemi oktató és polgári ügyszakos bírósági titkár. Könyvének központi kérdése az, hogy vajon az állam miképpen segítheti a szegényebbeket a magas költséggel járó bíróság előtti jogérvényesítésben, hogyan tudja az állam kompenzálni a jogkeresők jogi ismeretekben vagy anyagi lehetőségekben mutatkozó hiányosságait. A kötet a római jogtól napjainkig mutatja be a jogi segítségnyújtás magyarországi és nemzetközi intézményrendszerét, az összehasonlító jog módszerével különféle megoldási lehetőségeket vesz vizsgálat alá és értékel. A munka a szerző 2011-ben megvédett doktori disszertációján alapul. (F. Á.)

- Versenyjogi jogsértések - magánjogi jogkövetkezmények

Kisfaludi András (szerk.)

ELTE Eötvös Kiadó, Budapest, 2012

(Sorozat: ELTE Jogi Kari Tudomány, ISSN 2060-9361; 18.)

Kézikönyv. Terjedelem: 257. Bibliográfia nincs. ISBN 9789633121429

- A szerzők egyetemi oktatók és gyakorlati szakemberek. Jelen kötetben azt vizsgálják, hogy a versenyjogi jogsértések esetén mennyiben szükséges, illetőleg lehetséges a közjogi és magánjogi jogkövetkezmények halmozása, továbbá hogy milyen esetekben melyik eszköztár bír elsöbbséggel. A könyv négy nagy tartalmi egységéből az első a kártérítéssel mint magánjogi szankcióval foglalkozik, a másodikban az engedékenységi politika és a magánjogi igények kapcsolata kerül terítékre, a harmadik a semmisség polgári jogi jogkövetkezményét taglalja, míg az utolsó részben a teljesítésre kötelezés szankciója kerül tárgyalásra. (B. L.) 
- Piacszabályozás és jogorvoslat. A piacszabályozói döntések bírói gyakorlata, különös tekintettel az elektronikus hírközlésre

KovÁcs András György

(Sorozat: Infokommunikáció és jog könyvek, ISSN 2060-5021)

HVG-ORAC, Budapest, 2012

Kézikönyv. Terjedelem: 325. Bibliográfia: 289-319. ISBN 9789632581675

- A szerző a Kúria bírája. A kötet a hírközlési szabályozás és különösen annak a jogorvoslati szakhoz kötődő jogi kérdéseit vizsgálja, sajátosan bírói szempontból. A szerző azonban nem elégszik meg a tárgykört érintő jogesetek áttekintésével és értékelésével, hanem „A jogorvoslat hatékonysága” címü fejezetben konkrét javaslatokat is tesz a bírói felülvizsgálat rendszerének újragondolására. A kötet több érdekes kapcsolódó kérdéskört is tárgyal, így például a gazdasági alkotmányosság vagy a szabályozó hatóságok és az általuk kiadott „soft law” dokumentumok jogi státuszának problémáit. (T. E.)

- Gyakorlati útmutató az egyes szerződéstípusokhoz

KovÁcs Bálint-NemEssánYı Zoltán

(Sorozat: Saldo Szakkönyv Sorozat, ISSN 2062-8218; Gazdálkodási kézikönyvek, ISSN 1788-3245)

Saldo, Budapest, 2012

Kézikönyv. Terjedelem: 256. Bibliográfia: 255-256. ISBN 9789636384401

- A szerzők egyetemi oktatók. Az elsősorban az üzleti élet szereplőinek szánt kötetben a gazdasági életben legnagyobb jelentőséggel bíró szerződéstípusokat tekintik át. Így bemutatásra kerülnek az adásvétel, a szállítási szerződés, a közüzemi szerződés, a vállalkozási szerződés és annak nevesített fajtái, a mezőgazdasági termékértékesítési szerződés, a bérleti, lakásbérleti és haszonbérleti szerződés, a letéti szerződés, a megbízás, a fuvarozási szerződés, a bizományi szerződés, a szállítmányozási szerződés, a banki ügyletekkel kapcsolatos szerződéstípusok, az ajándékozási szerződés, a haszonkölcsön szerződés, az önálló kereskedelmi ügynöki szerződés, a biztosítás, a lízingszerződés, a faktoring és a franchise szabályai. (T. E.)

- Magyar polgári jog: Szerzői jog és iparjogvédelem

LonTAI Endre-FALUdI Gábor-GYERTYÁNFY Péter-VÉKÁs Gusztáv

Eötvös József Kiadó, Budapest, 2012

Tankönyv. Terjedelem: 338. Bibliográfia az egyes fejezetek végén.

ISBN 9789639955318

- A szerzők egyetemi oktatók, illetve szabadalmi joggal foglalkozó szakemberek. A kötet oktatási segédanyagként átfogóan ismerteti a szellemi alkotások jogát, így több helyen vázlatokkal és táblázatokkal segíti az ismeretek elsajátítását. A szerzői jogot és az iparjogvédelmet külön fejezetekben, hasonló módszerrel tekinti át: elsőként az általános elméleti kérdéseket, majd a részletszabályokat ismerteti. Mindezt megelőzi egy általános, történeti és rendszertani kérdésekkel foglalkozó bevezető fejezet. A Függelék felvázolja az iparjogvédelem szervezeti felépítését. (T. E.) 
- Külföldi közokiratok a magyar közjegyzöi és más hatósági eljárásban MÁTÉ Viktor HVG-ORAC, Budapest, 2012

Kézikönyv. Terjedelem: 313. Bibliográfia: 307-313. ISBN 9789632581446

- A szerző gyakorló közjegyző. A könyv betekintést enged a közjegyző egyik legfontosabb feladatkörébe: az okirat-szerkesztési tevékenységbe, és annak is az egyik legizgalmasabb területével, a külföldi okiratokkal foglalkozik. A munka három nagy egységre tagolódik: egyrészt foglalkozik az okiratok nemzetközi megfeleltetésének kérdésével általában, másrészt bemutatja a konkrét külföldi okirattípusokat, harmadrészt részletesen feltárja az egyes országok hatósági és közokirati rendszerét. A szerző szándéka szerint a kötet általánosságban is közelebb viszi az olvasót a közjegyzői munka megismeréséhez. (M. J.)

- A fájlcsere dilemma. A perek lassúak, az internet gyors Mezes Péter

(Sorozat: Infokommunikáció és jog könyvek, ISSN 2060-5021)

HVG-ORAC, Budapest, 2012

Monográfia. Terjedelem: 300. Bibliográfia: 275-299. ISBN 9789632581576

- A szerző egyetemi oktató. A kötet korunk egyik nagy problémájával foglalkozik: a fájlcserélésnek a technológiai fejlődéssel és a fogyasztói társadalom igényeivel való összeegyeztethetőségével, annak lehetséges módjaival. A fájlcserélés mindennapi gyakorlattá válásának jelenségét nem pusztán jogi problémaként kezeli a szerző, hanem annak technológiai, történeti, társadalmi és kulturális vonatkozásait is szem elött tartja, és kísérletet tesz a területtel kapcsolatos elavult jogi terminológia és meghaladott gondolkodásmód megváltoztatására. (T. E.)

- A fogyasztóvédelmi jog európai gyökerủ magyar szabályozása I-II.

MiskolCZI Bodnár Péter-SÁndor István

(Sorozat: Bethlen-sorozat, ISSN 2062-2546)

Patrocinium, Budapest, 2012

Egyetemi jegyzet. Terjedelem: 124. [I.], 165. [II.] Bibliográfia a lábjegyzetekben [I.] és 156-165. [II.] ISBN 9786155107900 [I.], 9786155107917 [II.]

- A szerzők egyetemi oktatók. A kétkötetes munkában meglehetősen röviden, ám lényegre törően ismertetik a hallgatók számára alapvető fogyasztóvédelmi jogi ismereteket. Az Általános rész a jogterület általános céljai, sajátosságait, míg a Különös rész a fogyasztók érdekeit védeni kívánó szabályokat, jogintézményeket ismerteti. A jegyzet harmadik részében a fogyasztóvédelem körébe tartózó igényérvényesítés intézményesített formáit tárgyalja, többek között a különböző hivatalok, békéltető testületek eljárásait és a közérdekủ kereseteket. (B. L.)

- Nemzetközi magánjog

NAGY Csongor István

Második, átdolgozott, bővített kiadás. HVG-ORAC, Budapest, 2012

Tankönyv. Terjedelem: 304. Bibliográfia: 292-297. és a lábjegyzetekben.

ISBN 9789632581781 
- A szerző egyetemi oktató és ügyvéd. Tankönyve a 2011-es első kiadásához hasonlóan egységes szerkezetben tárgyalja a nemzetközi kollíziós magánjog és a kapcsolódó jogterületek uniós és magyar joganyagát. Az új, bővített kiadásra azért volt szükség, mert a nemzetközi magánjog területén új uniós rendeleti szabályok léptek hatályba. A második kiadás ezeket is tárgyalva tartalmazza a teljes hatályos joganyagot két nagy egységben: elsőként a kollíziós jogot (külön alfejezetekben mutatva be az egyes szabályozási területeket, úgy, mint a személyek jogát, a szellemi alkotások jogát, az öröklési jogot stb.), majd a nemzetközi polgári eljárásjogot az uniós szabályozási területeken (közös joghatósági, elismerési, végrehajtási rendeletek). (K. G. M.)

\section{- Végrendelet}

Orosz Árpád

(Sorozat: Bírói gyakorlat füzetek, ISSN 2063-725X; 1.)

Opten, Budapest, 2012

Döntvénytár/Kézikönyv. Terjedelem: 185. Bibliográfia nincs. ISBN 978615512202

- A szerző a Kúria bírája. A füzet végrendelkezéshez kapcsolódó, magyarázott bírósági döntések gyűjteményét tartalmazza. A régi Ptk.-n alapuló több tucat döntésböl kirajzolódnak a végrendelet jogintézményéhez kapcsolódó legfontosabb ismeretek (pl. a végrendelet alaki és anyagi kellékei, a végintézkedés szabadsága stb.), az esetekhez ugyanis a szerző saját értékelést is füz. A kötet így kézikönyvként is használható. (F. Á.)

- Szerződéskötés, szerződéses kötelmek az agrárpiacokon

Orlovits Zsolt (szerk.)

(Sorozat: Business sorozat, ISSN 2063-8868)

Magyar Agrárkamara-Szaktudás, Budapest, 2012

Szakkönyv. Terjedelem: 166. Bibliográfia: 165. ISBN 9786155224232

- A szerzők egyetemi oktatók és gyakorlati szakemberek. A könyv a mezőgazdasági alapanyag-termeléssel és áruforgalommal összefüggö, fontosabb tipikus és atipikus szerződések alapvető kérdéseit tárgyalja, illetve magyarázza a gyakran elöforduló kifejezéseket és kikötéseket. A kötet a vonatkozó jogszabályi környezet, valamint a kapcsolódó ítélkezési gyakorlat ismertetésén túl konkrét mintaszerződéseket is közöl. A kötet elsősorban az agrárágazatban tevékenykedő vállalkozások illetve gazdálkodók számára készült. (K. G. M.)

\section{- Iparjogvédelem}

Posteinerné Toldi Márta (szerk.)

Szellemi Tulajdon Nemzeti Hivatala, Budapest, 2012

Tankönyv. Terjedelem: 253. Bibliográfia: 246-252. ISBN 9789639157682

- A kötet a Szellemi Tulajdon Nemzeti Hivatalának iparjogvédelmi szakemberei által írt oktatási segédanyag, amely az iparjogvédelemre vonatkozó szabályozás áttekintésén túl a rendszerbeli összefüggéseket is igyekszik bemutatni. Így nem csak az iparjogvédelmi oltalmi formákat tárgyalja, hanem kitér például az innovációs folyamatokra, a magyar innovációs rendszer föbb vonásaira, valamint az 
iparjogvédelmi információszerzés jelentőségére és forrásaira is. Az iparjogvédelmi eljárásokkal külön fejezet foglalkozik. (T. E.)

- A sajtó-helyreigazítás bírósági gyakorlata

PRIBULa László

HVG-ORAC, Budapest, 2012

Monográfia. Terjedelem 168. Bibliográfia nincs. ISBN 9789632581613

- A szerző egyetemi oktató és ítélötáblai bíró. A kötet a sajtó-helyreigazítás jogintézményének komplex bemutatására törekszik. Ennek megfelelően elhelyezi a jogintézményt a személyhez füződő jogok védelmi rendszerében, és megállapítja a személyhez füződő jogok védelmét garantáló eljárásokkal való kapcsolatát. Részletesen feltárja és elemzi a sajtó-helyreigazítás jogszabályi hátterét és bírósági gyakorlatát. A munka az intézmény elméleti és rendszertani helyének meghatározásán túl bemutatja a jogérvényesítés anyagi jogi alapjait, majd eljárási szabályait is. (M. J.)

- Tansegédlet a polgári jogi záróvizsgához: „C” tételek

SÁNDOR István

(Sorozat: Werbőczy-sorozat, ISSN 2062-2538)

Második, átdolgozott kiadás. Patrocinium, Budapest, 2012

Egyetemi jegyzet. Terjedelem: 192. Bibliográfia az egyes tételek után. ISBN 9786155107573

- A szerző egyetemi oktató és ügyvéd. A jegyzet célja elsősorban az államvizsgára történő felkészülés segítése, így a kötet vázlatosan áttekinti a kötelmi jogi tételeket, megjelöli a tételek részletes elsajátításához szükséges kötelező és ajánlott irodalmat és jogszabályokat. A jogszabályi hátteret még az 1959. évi IV. törvény adja, így ajánlott a hatályos joganyaggal való összevetés. (U. K.)

- Elöadásvázlatok a kötelmi jog különös részéböl

Sándor István (szerk.)

(Sorozat: Bethlen-sorozat, ISSN 2062-2546)

Második, átdolgozott és kibővített kiadás. KRE ÁJK-Patrocinium, Budapest, 2012 Egyetemi jegyzet. Terjedelem: 304. Bibliográfia az egyes fejezetek végén. ISBN 9786155107597

- A szerzők egyetemi oktatók és gyakorlati szakemberek. A tansegédletben, amely az elöadásokon és szemináriumokon elhangzottak összefoglalóit közli, az önálló szemeszterben oktatott kötelmi jog különös része, azaz az egyes szerződéstípusok kerülnek feldolgozásra. A jegyzet felépítése többnyire igazodik a Ptk. felosztásához (tekintettel az új Ptk. tervezetére is), de tárgyalja a Ptk.-n kívüli szerződéstípusokat is. (K. G. M.)

- A média-értéklánc szerzői jogi vonatkozásai

SARKADY lldikó-GRAD-Gyenge Anikó

(Sorozat: Médiatudományi Könyvtár, ISSN 2063-5222; 4.)

Médiatudományi Intézet, Budapest, 2012

Kézikönyv. Terjedelem: 139. Bibliográfia: 135-139. ISBN 9786155302008 
- A szerzők elméleti és gyakorlati szakemberek, illetve oktatók. Könyvükben a médiajog és a szerzői jog határterületeivel kapcsolatos aktuális kihívásokat, megoldásokat értékelik. Elsőként a szerzői jog és a sajtójog kialakulásában, hazai és külföldi fejlödésében tapasztalható közös és eltérő vonásokat elemzik. A második és harmadik fejezet a szükebb témával, a média-értéklánccal foglalkozik általános és szerzői jogi megközelítésben, ez utóbbi kapcsán a hatályos szabályozást vizsgálva. Végül a médiaszolgáltató szerzői jogilag releváns tevékenységéröl, azaz a nyilvánossághoz közvetítésröl kaphat történeti és hatályos jogi áttekintést az olvasó. A mü számos szakirodalmi forrást, bírósági döntést és SZJSZT véleményt dolgoz fel, illusztrációként folyamatábrákat tartalmaz. (P. O.)

- Családjog

Somfal Balázs

(Sorozat: Dialóg Campus szakkönyvek, ISSN 1417-7986; Jogi szakvizsga segédkönyvek, ISSN 1587-6659)

Harmadik, átdolgozott kiadás. Dialóg Campus, Budapest-Pécs, 2012

Tankönyv. Terjedelem: 184. Bibliográfia: 8. ISBN 9789639950719

- A szerző egyetemi oktató. A kötet jogi szakvizsga segédkönyvként a magyar családjog szabályait mutatja be. A vonatkozó hazai jogszabályok rendelkezéseinek ismertetése mellett a mü tartalmazza az adott fejezethez kapcsolódó releváns bírósági határozatok számát, illetve összefoglalóját. A kötet végén családjogi tárgyú iratminták találhatók. (K. J. M.)

- Bírósági végrehajtás: 1994. évi LIII. törvény a bírósági végrehajtásról (2012. szeptember 1.), kiegészítve a vonatkozó kollégiumi állásfoglalásokkal

Szilner György (szerk.)

Novissima, Budapest, 2012

Jogszabálygyüjtemény. Terjedelem: 132. Bibliográfia nincs.

ISBN 9786155175541 (F. F.)

- Cégtörvény: 2006. évi V. törvény a cégnyilvántartásról, a bírósági cégeljárásról és a végelszámolásról; 1997. évi CXXXII. törvény a külföldi székhelyü vállalkozások magyarországi fióktelepeiröl és kereskedelmi képviseleteiröl (2012. szeptember 1.) Szilner György (szerk.)

Novissima, Budapest, 2012

Jogszabálygyüjtemény. Terjedelem: 143. Bibliográfia nincs.

ISBN 9786155175503 (F. F.)

- Gazdasági jog: 2006. évi IV. törvény a gazdasági társaságokról (2012. szeptember 1.)

Szilner György (szerk.)

Novissima, Budapest, 2012

Jogszabálygyüjtemény. Terjedelem: 107. Bibliográfia nincs.

ISBN 9786155175459 (F. F.) 
- Polgári perrendtartás: 1952. évi III. törvény a polgári perrendtartásról. Kiegészítve a vonatkozó kollégiumi állásfoglalásokkal és jogegységi határozatokkal (2012. szeptember 1.)

Szilner György (szerk.)

Novissima, Budapest, 2012

Jogszabálygyüjtemény. Terjedelem: 159. Bibliográfia nincs.

ISBN 9786155175497 (F. Á.)

- Polgári törvénykönyv: 1959. évi IV. törvény a Polgári törvénykönyvröl. Kiegészítve a vonatkozó kollégiumi állásfoglalásokkal és jogegységi határozatokkal (2012. szeptember 1.)

Szilner György (szerk.)

Novissima, Budapest, 2012

Jogszabálygyűjitemény. Terjedelem: 194. Bibliográfia nincs.

ISBN 9786155175480 (F. F.)

- Polgári perrendtartás: kiegészítve jogegységi határozatokkal és a bírói gyakorlattal (2012. február 1.)

Udvary Sándor (szerk.)

Novissima, Budapest, 2012

Jogszabálygyüjtemény. Terjedelem: 424. Bibliográfia nincs.

ISBN 9786155175176 (F. Á.)

\section{VEGYES TÁRGYÚ KÖTETEK}

- Il me semblait que j'étais moi-même ce dont parlait l'ouvrage - Liber Amicorum Endre Ferenczy

Boóc Ádám-Fekete Balázs (szerk.)

Patrocinium, Budapest, 2012

Tanulmánykötet. Terjedelem: 328. Bibliográfia a lábjegyzetekben. ISBN 9786155107863

- Az emlékkönyv szerzői az MTA TK Jogtudományi Intézetének kutatói. A kötettel Ferenczy Endrét, az MTA köztestületi tagját, elismert közjogászt, pénzügyi jogászt köszöntik 65. születésnapja alkalmából. A harmincegy, magyar, angol és francia nyelvű tanulmány témái rendkívül szerteágazóak, egyaránt érintenek alkotmányjogi, közigazgatási jogi, munkajogi, polgári jogi, európai uniós és nemzetközi jogi kérdéseket. A kötetet az ünnepelt publikációinak jegyzéke zárja. (F. F.)

- A közigazgatási eljárásjog alapjai. A büntetőjog alapjai. A családjog és az öröklési jog alapjai

CsÁkI-Hatalovics Gyula-Deres Petronella-FÁBIÁn Ferenc

(Sorozat: Bocskai-sorozat, ISSN 2063-1464)

Patrocinium, Budapest, 2012

222 Egyetemi jegyzet. Terjedelem: 173. Bibliográfia nincs.

ISBN 9786155107603 
- A szerzők egyetemi oktatók. A kötet egyedi jogesetek oldaláról mutatja be a címben szereplő három jogterület egyes intézményeit, eljárásait. Valamennyi példa (oktatási szempontokat is követve) három szerkezeti egységből építkezik: egy rövid, lényegre törő esetleírásból, majd kérdésekből, végezetül pedig a helyes megoldásból. A jegyzet kiscsoportos foglalkozások, szemináriumok számára ideális segédanyag lehet. (B. A.)

- Viva Vox luris Civilis: Tanulmányok Sólyom László tiszteletére 70. születésnapja alkalmából

Csehi Zoltán-Schanda Balázs-Sonnevend Pál (szerk.)

(Sorozat: Bibliotheca iuridica, Libri amicorum, ISSN 1587-1509; 42.; Xenia, ISSN 2061-9227)

Szent István Társulat, Budapest, 2012

Tanulmánykötet. Terjedelem: 632. Bibliográfia a lábjegyzetekben.

ISBN 9789632773278

- Az ünnepi kötetben különböző jogtudományi területeken tevékenykedö magyar és külföldi jogtudósok (pl. Roman Herzog, Dieter Grimm, Kim Lane Scheppele) írásai találhatók, melyekkel Sólyom László professzort, a magyar Alkotmánybíróság első elnökét, volt köztársasági elnököt köszöntik 70. születésnapja alkalmából. A magyar, angol és német nyelvű tanulmányok között alkotmányjogi, nemzetközi jogi, polgári jogi, kánonjogi, jogtörténeti és jogelméleti témájúakat is találunk. A közlemények a választott témát az ünnepelt pályafutásához, alkotmánybírói tevékenységéhez kapcsolódva dolgozzák fel. A kötet az ünnepelt tudományos publikációinak jegyzékét is közli. (K. J.M.)

- Contemporary legal challenges: EU - Hungary - Croatia

Drinóczi, Tímea-Župan, Mirela-Ercsey, Zsombor-Vinković, Mario (szerk.)

Faculty of Law University of Pécs-Faculty of Law J. J. Stossmayer University of Osijek, Pécs-Osijek, 2012

Konferenciakötet. Terjedelem: 792. Bibliográfia a lábjegyzetekben. ISBN 978963642472 5, 9789636072699

- A kötet a Pécsi Tudományegyetem és a horvátországi Osijek egyetemének jogi karai közötti, az Európai Unió által is támogatott együttmüködés keretében készült. Az angol nyelvü tanulmányok, melyeket a 2012. február 16-18. között Osijekben megrendezett konferencián is bemutattak, különböző jogterületeket érintenek, így a jogelmélet, az európai uniós jog, a közigazgatási jog, a büntetőjog, a polgári anyagi és eljárási jog, az emberi jogok és a felsőoktatás témakörében olvashatunk közleményeket. A terjedelmes kötet 70 szerző 33 tanulmányát tartalmazza, valamennyi tanulmány egy-egy (esetenként több) magyar és horvát szerző közös munkája. A kötet angol, magyar és horvát nyelven is letölthető a projekt honlapjáról. (F. F.) 
- Pro Vita Et Scientia: Ünnepi kötet Jobbágyi Gábor 65. születésnapja alkalmából Tattay Levente-Pogácsás Anett-Molnár Sarolta (szerk.) (Sorozat: Xenia, ISSN 2061-9227)

Szent István Társulat, Budapest, 2012

Tanulmánykötet. Terjedelem: 358. Bibliográfia fejezetenként. ISBN 9789632773513

- Az ünnepi kötet Jobbágyi Gábor, a PPKE JÁK professzora 65. születésnapjának alkalmából készült. A könyvben 26 tanulmány kapott helyet, melyek nagyobb része különböző magánjogi témaköröket fog át. Így a kötetben - igazodva az ünnepelt széles érdeklődési köréhez - egyaránt találunk orvosi jogi, családjogi, szerzői jogi, kötelmi jogi, valamint kereskedelmi jogi, társasági jogi témájú közleményeket. A kötetben kisebb részben képviseltetik magukat a közjogtudomány körébe eső tanulmányok is (pl. a Szent Korona-tan vagy a vallásszabadság témakörében). (B. L.)

- Dikaiosz Logosz. Tanulmányok Kovács István emlékére Trócsányi László (szerk.) Pólay Elemér Alapítvány, Szeged, 2012 Tanulmánykötet. Terjedelem: 462. Bibliográfia az egyes fejezetek végén és a lábjegyzetekben. ISBN 9789639650886

- A szerzők egyetemi oktatók és gyakorlati szakemberek. Kovács István jogtudós, akadémikus volt; a tanulmánykötet a Szegeden, 2010. november 18-19-én tartott Kovács István Emléknapok elöadásainak szerkesztett anyaga. A 2010-ben elkezdődött alkotmányozás folyamatához csatlakozva az egyes tanulmányok a köztársasági alkotmány gyakorlatának tanulmányozásával és értékelésével foglalkoznak. A tanulmányok között alkotmányjogi, jogelméleti, magánjogi, munkajogi, nemzetközi jogi és büntetőjogi tárgyúakat is találunk. (F. P. P.) 